Review

\title{
Chirality in Organic and Mineral Systems: A Review of Reactivity and Alteration Processes Relevant to Prebiotic Chemistry and Life Detection Missions
}

\author{
Carina Lee $^{1,2, *}$, Jessica M. Weber ${ }^{3}$, Laura E. Rodriguez ${ }^{3} \mathbb{D}$, Rachel Y. Sheppard ${ }^{3} \mathbb{D}$, Laura M. Barge $^{3}$, \\ Eve L. Berger ${ }^{4}$ and Aaron S. Burton ${ }^{2}$ (D) \\ 1 Lunar \& Planetary Institute, Universities Space Research Association, Houston, TX 77058, USA \\ 2 National Aeronautics \& Space Administration, Johnson Space Center, Houston, TX 77058, USA; \\ aaron.burton@nasa.gov \\ 3 National Aeronautics \& Space Administration, Jet Propulsion Laboratory, California Institute of Technology, \\ Pasadena, CA 91109, USA; jessica.weber@jpl.nasa.gov (J.M.W.); laura.rodriguez@jpl.nasa.gov (L.E.R.); \\ rachel.y.sheppard@jpl.nasa.gov (R.Y.S.); laura.m.barge@jpl.nasa.gov (L.M.B.) \\ 4 Texas State University-Jacobs JETS-National Aeronautics \& Space Administration, Johnson Space Center, \\ Houston, TX 77058, USA; eve.l.berger@nasa.gov \\ * Correspondence: carina.h.lee@nasa.gov; Tel.: +1-281-483-5153
}

check for updates

Citation: Lee, C.; Weber, J.M.; Rodriguez, L.E.; Sheppard, R.Y.; Barge, L.M.; Berger, E.L.; Burton, A.S. Chirality in Organic and Mineral Systems: A Review of Reactivity and Alteration Processes Relevant to Prebiotic Chemistry and Life Detection Missions. Symmetry 2022, 14, 460. https://doi.org/10.3390/ sym 14030460

Academic Editor: Yannick Vallée

Received: 16 January 2022

Accepted: 16 February 2022

Published: 24 February 2022

Publisher's Note: MDPI stays neutral with regard to jurisdictional claims in published maps and institutional affiliations.

Copyright: (c) 2022 by the authors. Licensee MDPI, Basel, Switzerland. This article is an open access article distributed under the terms and conditions of the Creative Commons Attribution (CC BY) license (https:/ / creativecommons.org/licenses/by/ $4.0 /)$.

\begin{abstract}
Chirality is a central feature in the evolution of biological systems, but the reason for biology's strong preference for specific chiralities of amino acids, sugars, and other molecules remains a controversial and unanswered question in origins of life research. Biological polymers tend toward homochiral systems, which favor the incorporation of a single enantiomer (molecules with a specific chiral configuration) over the other. There have been numerous investigations into the processes that preferentially enrich one enantiomer to understand the evolution of an early, racemic, prebiotic organic world. Chirality can also be a property of minerals; their interaction with chiral organics is important for assessing how post-depositional alteration processes could affect the stereochemical configuration of simple and complex organic molecules. In this paper, we review the properties of organic compounds and minerals as well as the physical, chemical, and geological processes that affect organic and mineral chirality during the preservation and detection of organic compounds. We provide perspectives and discussions on the reactions and analytical techniques that can be performed in the laboratory, and comment on the state of knowledge of flight-capable technologies in current and future planetary missions, with a focus on organics analysis and life detection.
\end{abstract}

Keywords: chirality; homochirality; origins of life; organics; minerals; biosignatures; life detection; prebiotic chemistry; enantiomeric excess

\section{Review Summary}

This review article aims to bring together multiple perspectives on research centered around chiral determination in organic and mineral systems with a focus towards prebiotic chemistry and origins of life. Section 2 provides an introduction to the prebiotic chemistry field to give context and highlight the importance of understanding what chirality is and how it could have played a role in the origins of life. Included in this introduction is a brief summary and overview on the use of enantiomeric excess as a biosignature and the various hypotheses that have been proposed that led to the emergence of homochirality in biological systems.

The next part is separated into sections that review chirality in the two systems of focus: (1) organic systems, and (2) mineral systems. Sections 3 and 4 detail different types of organic chirality that can occur to highlight how chemical structure affects chiral properties and organic reactivity, especially in organic synthesis. This section draws heavily from examples in the pharmaceutical industry, which focus on organic synthesis/catalysis 
research into asymmetric reactions. We present some examples of how chirality influences organometallic systems and their relevance to extraterrestrial materials and the origins of life. Here we present a table that provides examples of enantioselective reactions and asymmetric cross-coupling reactions relevant to various research disciplines. We summarize this section by highlighting the need to consider organic reactions within a geological framework, so that reaction products due to post-depositional geological alteration processes can be properly assessed and contextualized.

Section 5 discusses minerals that are relevant to prebiotic systems in the context of the composition of extraterrestrial bodies that may be explored during life detection missions and presents a table of the mineral and ice composition of major rocky planetary bodies in the Solar System. The chirality of mineral systems and its potential influence on organic systems and driving enantiomeric excess is discussed in Section 6. In particular, the section describes how mineral systems display a diverse range of chiral properties and introduces the concepts of enantiomorphic minerals, achiral minerals with chiral faces, local chiral sites, factors that influence a mineral's degree of enantioselectivity, mineral-organic interactions driving enantiomeric excess, as well as future directions for research in this field.

Section 7 of this review takes the geological context further by discussing geochemical processes involved in the preservation, alteration, and detection of organic matter as a primary and robust method for understanding the composition of primitive microorganisms as life began to evolve on Earth. In lieu of macroscopic, fossilized remains in the geological record, the study of early life involves examining molecular compositions, some of which have excellent preservation potential and can be traced back to specific organisms. Sections 7.1-7.3 detail the reactions and processes that occur during organic preservation and how chirality-particularly the stereochemical configuration of membrane lipidschanges during sequestration into refractory phases that get preserved over geologic time. In addition to terrestrial geochemical alteration processes, in Section 7.4 we discuss the parent body alteration processes that occur on asteroids and how the composition and chirality of organics are affected.

Section 8 summarizes analytical instrumentation and asymmetric solution phase and solid-state reactions. Section 8.1 includes a table that documents various separation and analytical methods for determining chirality and which of these has been proposed or flown on spaceflight missions. In the solution phase reactions, we detail three of the relevant reactions to prebiotic chemistry and origins of life: reductive amination (Section 8.2.1), Strecker synthesis (Section 8.2.2), and the formose reaction (Section 8.2.3). In Section 8.3 we focus on solid-state mechanochemical reactions, which have been recently shown to be viable options in the study of the origins of life. Additionally, we summarize some experimental studies on impact simulation that are directly related to the synthesis of amino acids, peptides, and molecules of prebiotic interest.

The final section of the review summarizes our recommendations for future research and discusses mission-relevant instrumentation for the analysis of organics and minerals and organic chirality (Section 9.1). We highlight the importance of continued instrument development (Section 9.2), contamination control (Section 9.3), and multidisciplinary collaboration (Section 9.4) in order to further the study of chirality in organic and mineral systems that is geared towards understanding the origins and contexts of how life evolved on Earth and where and how to find it elsewhere.

\section{Prebiotic Chemistry, Chirality, and the Origins of Life}

\subsection{Chirality, Homochirality, and Enantiomeric Excess}

Characterizing the organic chemical composition on planetary bodies is a key component in the search for habitable environments and evidence of extinct or extant life. The field of prebiotic chemistry focuses on how simple organic precursor compounds could have been synthesized and how they could have evolved into complex, functioning biomolecules, such as nucleic acids, peptides, and proteins [1-7]. These building block 
precursors were likely required to carry out metabolic reactions and the information storage and transfer necessary for the maintenance and replication of living organisms $[8,9]$.

Molecules can be arranged in three-dimensional space from a single point source (i.e., at a carbon atom). When a carbon atom has four distinct functional groups attached to it (i.e., is $s p^{3}$ hybridized), the molecule can exist as one of two possible three-dimensional shapes, and that carbon atom is termed a "chiral center". Molecular chirality—or handednesswhereby a molecule is not superimposable on its mirror image, is a property that is of great interest in the field of prebiotic chemistry. Chiral molecules are optically active; that is, they rotate plane-polarized light in opposite directions depending on their chirality. Enantiomers of chiral molecules possess identical chemical and physical properties, with the exception of how they interact with other chiral molecules or electromagnetic radiation. Thus, chirality can affect various properties of important molecules, such as amino acids and sugars (Figure 1), including: molecular self-assembly, asymmetric reactions/reactivity, molecular recognition and replication, and light, or spin polarization [10-13].

\section{Examples of chiral prebiotic molecules}<smiles>N[C](CS)C(=O)O</smiles>

amino acids cysteine

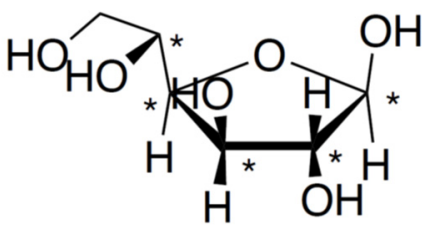

sugars

glucose

Figure 1. Amino acids and sugars are examples of chiral molecules relevant to prebiotic chemistry. The asterisk $\left(^{*}\right)$ indicates the chiral carbon center(s). (Left) is the amino acid cysteine $\left(\mathrm{C}_{3} \mathrm{H}_{7} \mathrm{NO}_{2} \mathrm{~S}\right)$; (right) is the sugar glucose $\left(\mathrm{C}_{6} \mathrm{H}_{12} \mathrm{O}_{6}\right)$.

Homochiral polymers are a result of the preference for one enantiomer over the other; biology on Earth has evolved to use homochiral proteins and nucleic acids, which are made up of L-amino acids and D-sugars, respectively [14,15], although there are rare exceptions [16]. Notably, life generally relies on L-amino acid and D-sugar monomers for metabolic functions as well. L- and D- are stereochemical designations for discerning enantiomeric pairs of amino acids and sugars, and are described in more detail in Section 3.1. Without a seed (i.e., a solid catalyst or already chiral reactant) that can induce asymmetry, chemical reactions will synthesize products in racemic mixtures, i.e., an equal mix of both enantiomers. Enantiomeric excess (ee) reflects the abundance of one particular enantiomer over the other and can be determined as a ratio of the observed specific rotation of the mixture over the specific rotation of the pure enantiomer, typically calculated as ee $=[(L-D) /(L+D)] \times 100[17]$. For example, an enantiopure product will have $100 \%$ of one enantiomer and $0 \%$ of the other, and racemic mixtures have ee of $0 \%$, as there is no excess of one enantiomer over the other.

\subsection{Chirality in a Prebiotic Context}

Before life arose on Earth, nucleosynthetic reactions occurring in the interstellar medium created elements that formed primitive organic compounds [18-22]. These organic compounds can be preserved in asteroids and comets and are delivered to Earth within carbonaceous chondrite meteorites [23]. Homochirality and the amplification of the enantiomeric imbalance resulting in the observed chirality of biological polymers has been hypothesized to have originated from either terrestrial or extraterrestrial processes before abiogenesis (i.e., the origins of life) or afterwards as a consequence of biological evolution [24]. Among the prebiotic hypotheses, there are theories that propose either 
stand-alone or deterministic processes [15]. For example, the autocatalytic mathematical model developed by Frank [25] proposed that homochirality was amplified through the catalysis of a starting compound, which repeatedly synthesizes itself in one structural configuration while excluding the other [26]. Additionally, amplification in terrestrial environments of ee could have occurred with the aid of chiral reactants or substrates, as this has been demonstrated to promote the synthesis of specific enantiomers [27-29].

The effect of circularly polarized light and other energy sources, such as galactic cosmic rays (GCRs), on the chirality of organics is also well studied, e.g., Ref. [14] and references therein [30-32]. While prebiotic molecules of interest are generally synthesized in racemic mixtures, moderate abiotically synthesized ee have been measured in meteorites $[14,17]$ and references therein. The organic composition of meteorites, specifically of hydroxy acids [33,34], typically demonstrate racemic composition and, in some cases of amino acids and sugar derivatives, meteoritic organics demonstrate an ee approaching that observed in biology [35-46].

\subsection{Enantiomeric Excess as a Biosignature}

Enantiomeric excess (ee) of organic molecules has been proposed as a biosignature based on our observations and knowledge of molecular biochemistry on Earth [17,47-49]. However, it remains to be observed whether ee is a robust indicator of life, given that it is unknown (1) if abiotic processes can generate significant enantiomeric excess such that it would be mistaken for a false positive for life detection; (2) whether the chemical evolution of near-homochiral polymers was required for life to evolve (if not, lack of ee could lead to false negatives); (3) if such chemistry is a requirement for all life or just Earth-like life; or (4) that biological systems always utilize a single enantiomer for building functional polymers. To expand on the fourth point, it remains possible for extraterrestrial life to rely on homochiral polymers of various chiralities; for example, perhaps it could use a protein composed of D-amino acids for one function and another composed of L-amino acids for another. Terrestrial life does this to some extent in that it incorporates only L-amino acids for building proteins, but uses D-amino acid monomers for various functions [50,51]; bacteria also use both D- and L-amino acids for the production of peptidoglycan [52], and some bacterial strains have even been demonstrated to be capable of growing using D-amino acids and L-sugars [53].

Understanding the pathways and environments relevant to chirality is critical to determining how homochiral polymers evolved on Earth and how we can utilize it as a possible biosignature to look for potential life on other planetary bodies. Specifically, the origins of life and astrobiology fields aim to constrain the geochemical conditions under which primitive/abiotic racemic or slightly enantioenriched mixtures of organic molecules could have chemically evolved towards homochiral/near homochiral polymers utilized in life as we know it.

In this paper, we provide a perspective on the interaction between chirality in organic systems with minerals that are relevant in prebiotic environments. We explore geochemical reactions and scenarios, such as the binding and release of organic compounds from mineral matrices during alteration and preservation, and the astrobiological implications of these phenomena. In the terrestrial context, alteration is defined as any reaction that occurs after the primary deposition of organic matter during sedimentary diagenesis and catagenesis. In the extraterrestrial context, alteration refers to processes occurring on the parent body. Examples include thermal or aqueous processes, shock wave propagation, and brecciation. We also discuss the current state of knowledge regarding the impact of minerals on driving different types of ee and provide some future experimental directions that could address gaps that warrant further study of organic and mineral chirality in the context of prebiotic chemistry and the origins of life. 


\section{Organic Chirality}

\subsection{Point/Molecular Chirality}

There are various types of chirality that organic molecules can possess; some different types are shown in Figure 2 (as illustrated by the amino acid alanine, Figure 2a). Point or molecular chirality is chirality that is based around an atom, such as carbon. Molecules that have atoms where each functional group attached to it is distinct are termed chiral [54]. For carbon, this typically means that the carbon atom has four different groups attached. Compounds that are mirror images of one another but cannot be superimposed through rotation are termed enantiomers; those that are non-superimposable, non-mirror images are termed diastereomers (example shown in Figure 2b).

a

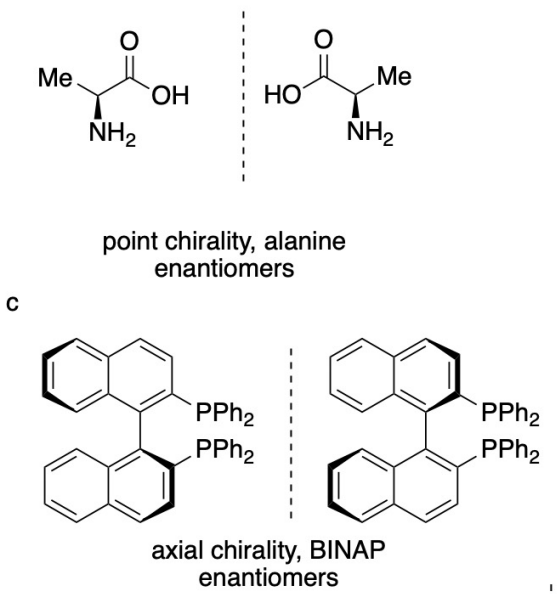<smiles>O=C[C@H](O)[C@@H](O)CO</smiles>

e

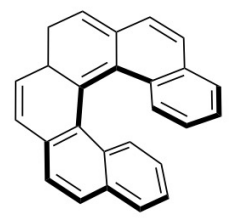

helical chirality, hexahelicene, enantiomers

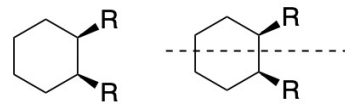

example of a meso compound - the opposite stereocenters make it symmetric

Figure 2. Examples of point/molecular chirality in organic molecules. (a) Enantiomers of the amino acid alanine. (b) Diastereomers of erythrose (left) and threose (right). (c) Axial chirality exhibited by BINAP enantiomers. (d) Planar chirality of the enantiomers of a ferrocene complex. (e) Helical chirality of hexahelicene enantiomers. Bottom: generic dialkylcyclohexane as an example of a meso compound with an internal plane of symmetry, which is achiral and does not possess enantiomers.

Often, enantiomers are described by their absolute configuration as $\mathrm{R}$ (rectus, right) or $\mathrm{S}$ (sinister, left). The difference between $\mathrm{R}$ and $\mathrm{S}$ involves assigning priority to the different substituents and determining whether the identified lowest to highest priority groups follows a clockwise direction (designated R) or counterclockwise direction (designated S). This method is also called the Cahn-Ingold-Prelog rules in organic nomenclature [55]. The $\mathrm{D} / \mathrm{L}$ designation is often used for sugars and amino acids; however, these do not directly line up with the R/S designation. In a Fisher projection of the molecule (for example, a sugar), the second to last carbon determines whether the molecule is D or L. If the hydroxyl group is on the left, the sugar is L, and if the hydroxyl group is on the right, the sugar is D. While the majority of chirality discussed in the context of origins of life is point/molecular chirality, there are other types of chirality that organics can possess, including axial, helical, and planar chirality, which we discuss below. 


\subsection{Heteroatom Chirality}

This work will primarily focus on point/molecular chirality relevant to carbon; however, other atoms can be chiral, including $\mathrm{P}, \mathrm{N}$, and $\mathrm{S}$, which are common heteroatoms in organic compounds. Additionally, other atoms within the carbon group, e.g., Ge and $\mathrm{Si}$, can exhibit chiral structures [56-59]. In the case of heteroatoms, $\mathrm{P}, \mathrm{N}$, and $\mathrm{S}$ in their neutral form would typically need a lone pair of electrons and three different substituents attached to be considered chiral. A key for maintaining this configuration (i.e., chirality at the heteroatom) is to limit inversion around the lone pair. This is known as pyramidal inversion and, in the specific case of $\mathrm{N}$, it is known as amine inversion. Amine inversion occurs rapidly at and below room temperature, and the $\mathrm{N}$ does not exhibit a chiral center. These are known as fluxional reactions and allow the enantiomers to racemize [60], which means pure enantiomers cannot be isolated. During amine inversion, in the transition state, there are three substituents arranged in the plane (co-planar) around the $\mathrm{N}$ atom, and the lone pair of electrons occupies an out-of-plane $\mathrm{p}$ orbital. Therefore, the structures containing chiral heteroatoms are often rigid or bulky, limiting the rate of inversion [61] and giving rise to enantiomers. Phosphine $\left(\mathrm{PH}_{3}\right)$ and chiral sulfur-containing compounds, such as sulfites, sulfoxides, sulfonium salts, and sulfinic esters, also undergo the same inversion as amines, but the rate at room temperature is much lower [62,63]. Therefore, chiral P-phosphines and appropriately substituted chiral S compounds are optically stable at room temperature [64].

Compounds containing chiral heteroatoms can be used as ligands or reagents in enantioselective reactions and are also used in drugs [65]. Examples of chiral S-based drugs include armodafinil and esomeprazole, which, as sulfoxides, always have a stereogenic $\mathrm{S}$ center due to the lone pair of electrons [66,67]. These drugs typically have an enantiopure form and a racemic form that display distinct chemical properties and are marketed for different uses. There is also similar research being conducted on P chiral centers e.g., Ref. [68], as well as $\mathrm{N}[69,70]$; however, the stereochemistry of the $\mathrm{N}$ atom makes it the most difficult heteroatom to control [70].

\subsection{Additional Forms of Chirality}

Molecules possessing features related to axial, helical [71], and planar [72] structure can also impart chirality in compounds that do not possess point chiral or stereogenic centers. Axial chirality is achieved when symmetry exists looking down an axis of a molecule; this commonly occurs in 2,2 '-disubstituted biaryls and dissymmetrically substituted allenes. Examples of axial chirality include the organophosphorus compound, 2,2'-bis (diphenylphosphino)-1,1-binaphthyl), or BINAP [73] and 2,2'-dihydroxy-4,4',6,6'tetramethylbiphenyl. In both examples, axial chirality is due to restricted rotation as a result of steric hindrance (Figure 2c). Helical chirality is based on twisting in 3D space, as demonstrated in the aromatic compound hexahelicene (Figure 2d). Similar to axial chirality, steric strain promotes the existence of a stereogenic axis, giving rise to chiral forms in helically chiral structures. Planar chirality is a system where the 2D structures are not superimposable. They contain two dissymmetric, non-coplanar rings that cannot be easily rotated (e.g., metallocenes including ferrocene, Figure 2e).

In addition, not all structures with chiral components are chiral when the structure is examined as a whole. For example, if a meso compound has two or more chiral components (stereogenic centers), they "cancel out" the asymmetry, as the structure contains an internal plane of symmetry (Figure 2). An example of a meso compound is 2,3-dichlorobutane, which is not optically active nor does it have enantiomers. Achiral structures can also be prochiral, meaning that the addition of a unique functional group to a non-stereogenic center could give rise to chirality in an asymmetric reaction. For example, in an asymmetric Strecker reaction (see Table 1, entries 2 and 3), the imine group is prochiral. This means that depending on the face (i.e., $\mathrm{Re}$ or $\mathrm{Si}$ ) that the reaction occurs on, different enantiomers (i.e., R and S) can be formed. In these mechanisms, other asymmetric components impart selectivity between the prochiral faces. 
Table 1. Examples of enantioselective reactions and the research field(s) they are relevant to. The focus of this review is the reactions relevant to prebiotic chemistry and the origins of life.

\begin{tabular}{|c|c|c|c|c|}
\hline Reaction & Starting Material & Product & Relevant Field(s) & References \\
\hline Soai & $\begin{array}{l}\text { pyrimidine-5- } \\
\text { carbaldehyde }\end{array}$ & pyrimidyl alcohol & Origins of life; autocatalysis & {$[26,74]$} \\
\hline Strecker & Aldehyde & Amino acid & $\begin{array}{l}\text { Origins of life, pharmaceutical and } \\
\text { natural product synthesis }\end{array}$ & [75] \\
\hline Strecker & Ketone & $\begin{array}{l}\alpha, \alpha \text {-disubstituted } \\
\text { amino acids }\end{array}$ & $\begin{array}{l}\text { Origins of life, pharmaceutical and } \\
\text { natural product synthesis }\end{array}$ & [76] \\
\hline Reductive amination & Alpha keto acid & Amino acid & $\begin{array}{c}\text { Origins of life, pharmaceutical and } \\
\text { natural product synthesis }\end{array}$ & {$[77,78]$} \\
\hline Kiliani-Fischer synthesis & Sugar & Monosaccharide & Origins of life & {$[79,80]$} \\
\hline Sharpless epoxidation & Allylic alcohols & 2,3-epoxyalcohols & $\begin{array}{l}\text { Pharmaceutical and natural } \\
\text { product synthesis }\end{array}$ & [81] \\
\hline $\begin{array}{c}\text { Sharpless } \\
\text { bishydroxylation }\end{array}$ & Alkene & Vicinal diol & $\begin{array}{l}\text { Pharmaceutical and natural } \\
\text { product synthesis }\end{array}$ & [82] \\
\hline Sharpless oxyamination & Alkene & Vicinal amino diol & $\begin{array}{l}\text { Pharmaceutical and natural } \\
\text { product synthesis }\end{array}$ & [83] \\
\hline Midland reduction & Carbonyl (ketone) & Alcohol & $\begin{array}{l}\text { Pharmaceutical and natural } \\
\text { product synthesis }\end{array}$ & [84] \\
\hline $\begin{array}{c}\text { Noyori asymmetric } \\
\text { hydrogenation }\end{array}$ & Keto ester & Hydroxy ester & $\begin{array}{l}\text { Pharmaceutical and natural } \\
\text { product synthesis }\end{array}$ & [85] \\
\hline Corey-Itsuno reduction & Ketone (achiral) & $\begin{array}{l}\text { Alcohol (chiral, } \\
\text { non-racemic) }\end{array}$ & $\begin{array}{c}\text { Pharmaceutical and natural } \\
\text { product synthesis; } \\
\text { industrial synthesis }\end{array}$ & {$[86,87]$} \\
\hline Asymmetric Diels-Alder & Diene and alkene & Cyclohexene & $\begin{array}{c}\text { Pharmaceutical and natural } \\
\text { product synthesis; } \\
\text { industrial synthesis }\end{array}$ & [88-93] \\
\hline \multicolumn{5}{|c|}{ Examples of asymmetric cross-coupling reactions } \\
\hline Suzuki-Miyaura & $\begin{array}{l}\text { Alkyl- or arylhalides } \\
\text { + organoborates }\end{array}$ & $\begin{array}{l}\text { Alkyl or aryl } \\
\text { compounds }\end{array}$ & $\begin{array}{c}\text { Pharmaceutical and natural } \\
\text { product synthesis; industrial } \\
\text { synthesis; catalysis }\end{array}$ & {$[13,94,95]$} \\
\hline $\begin{array}{l}\mathrm{Ni} / \text { Photoredox } \\
\text { dual catalysis }\end{array}$ & Varied & Varied & $\begin{array}{l}\text { Pharmaceutical and natural } \\
\text { product synthesis; catalysis }\end{array}$ & [96-99] \\
\hline $\begin{array}{l}\text { Buckwald-Hartwig } \\
\text { amination }\end{array}$ & Varied & Amine & $\begin{array}{l}\text { Pharmaceutical and natural } \\
\text { product synthesis; industrial } \\
\text { synthesis; catalysis }\end{array}$ & {$[100,101]$} \\
\hline
\end{tabular}

\subsection{Asymmetric Organic Synthesis Reactions}

Asymmetric reactions relevant to the origins of life include reductive amination and Strecker synthesis for synthesizing amino acids and the autocatalytic formose reaction for synthesizing sugars (see Section 8.2.3 for more details). Asymmetric reactivity is very important in the field of organic chemistry, as it is often a key consideration in pharmaceutical and natural product synthesis [102,103]. Notably the 2021 Nobel Prize in Chemistry was awarded for the discovery of chiral organocatalysis [104]. There are a variety of catalytic methods to create asymmetry in reactions (Table 1). Some examples include organocatalysis that utilize chiral compounds (such as proline) as the catalyst, which then imparts asymmetry [105-107]. For metal-based catalysis, the chiral component can often be the ligand of the metal catalyst; such ligands can include organics with point or axial chirality [108-110]. However, there are other methods to impart chirality with the use of transition metals [111]. 
There are also chiral pool materials that are enantiopure compounds and readily and naturally available, such as amino acids and certain carboxylic acids, e.g., refs. [112,113]. Chiral pool materials are often commercially available and can be used in total synthesis. Total synthesis-common in organic chemistry-is the complete chemical synthesis of an organic molecule and often a complex natural product, such as taxol, strychnine, or a pharmaceutical. In these syntheses, organic chemists need to design enantioselective reactions to access complex chiral products.

In asymmetric organic synthesis reactions, geologic context is not often considered. Instead, considerations for chiral/asymmetric starting materials are often based on availability and yield of product. Ideally, scientists who utilize organic syntheses to impart asymmetry aim to synthesize their natural product with high purity and selectivity, therefore the conditions are often heavily optimized towards achieving those objectives. In the field of prebiotic chemistry, the geologic context is important, as yield and/or selectivity are not often the final goal of these projects, but instead to determine the conditions that drive product distribution $[5,6]$.

\section{Organometallic Systems Related to Chirality}

Organometallic compounds, whereby a carbon atom is covalently bonded to a metal, play important roles in enantioselective organic synthesis and methodology [114,115], industrial synthesis [116], materials science, nanotechnology [117,118], pharmaceuticals, and medicinal research [119,120], and in prebiotic and metabolically relevant systems [121-124] and references therein. Organometallic reagents can be used in other reactions as reagents e.g., R-MgBr (where R = alkyl, allyl, aryl, or vinyl group) for Grignard reactions [125,126] and catalysts, i.e., Pd and Ni compounds for Heck reactions [127-129]. Cross-coupling reactions are a notable type of organometallic reactions where two organic fragments are coupled together with the use of a metal catalyst, such as the Suzuki reaction [130,131]. Cross-coupling reactions and the use of precatalysts are powerful techniques that can be used to form C-C, C-N, and other C-X bonds, e.g., Refs. [132-134], to synthesize materials relevant to all fields of chemistry. While there are a significant number of different cross-coupling techniques, far more often than not, the techniques have not been explored for selectivity. Table 1 lists some of the examples where the reactions are enantioselective. In addition to interest in bioactive-starting materials relevant to the pharmaceutical industry, some cross-coupling reactions could have relevance in prebiotic environments. For example, the copper-mediated cross coupling of cyanide and acetylene synthesized the amino acids: arginine, aspartic acid, asparagine, aspartate, glutamine, glutamate, and proline [135].

Many proteins are associated with organometallic complexes or metalloenzyme cofactors [136], as they assist with the stabilization of their structure and support other vital biochemical reactions [123] and references therein. Organometallic compounds have been demonstrated to catalyze the polymerization of peptides and proteins $[123,137,138]$. The metal ions stabilize spectator ions during peptide formation within their ligands and the amino or carboxyl group of amino acids is protected during peptide synthesis $[139,140]$.

Recently, there have been several reports of metal-organic compounds in meteoritic organic matter that have implications for understanding parent-body interactions with origins of life implications [141-143]. A study by Ruf and colleagues surveyed 61 meteorites over a wide range of petrologic types. They found dihydroxymagnesium carboxylates $\left[(\mathrm{OH})_{2} \mathrm{MgO}_{2} \mathrm{CR}\right]^{-}$in the soluble organic fraction that could be associated with metamorphic events, such as thermal alteration and shock events. These types of organometallic anion complexes had not been identified in meteorites prior to this study. Another study looked at the soluble organic fraction of 44 meteorites and found a novel homologous series of sulfur magnesium carboxylates. They appear to be thermally stable and their abundance was correlated with increasing thermal maturity [143]. Smith and colleagues looked at the origin of cyanide in the CM2 Murchison meteorite and found that it was primarily bound (and subsequently released) as iron cyanocarbonyl $\left(\left[\mathrm{Fe}^{\mathrm{II}}(\mathrm{CN})_{5}(\mathrm{CO})\right]^{3-}\right.$ 
and $\left.\left[\mathrm{Fe}^{\mathrm{II}}(\mathrm{CN})_{4}(\mathrm{CO})_{2}\right]^{2-}\right)$ organometallic complexes. These results suggest that cyanide in the form of iron cyanocarbonyl complexes could be a source for free cyanide delivered by meteorites and potentially be a precursor to catalytic centers of early enzymes, such as Fe hydrogenases [142]. Below, we describe mineral chirality and how organic reactions can impart chirality in organic-mineral systems in the context of prebiotically relevant environments.

\section{Minerals Relevant to Prebiotic Chemistry}

The composition of planetary surfaces varies based on the planet's histories, including its orbital position during early Solar System development, and subsequent physical, chemical, and space weathering processes (Table 2). 202 subdivided into broad categories of primary igneous minerals and secondary minerals produced by processes, including impacts, metamorphism, weathering, and volatile ices. Primary minerals include olivine, pyroxene, quartz, and feldspar. Secondary minerals include phyllosilicates, Fe oxides, carbonates, and sulfates. Common ices of volatile phases are driven by the "frost line" of that volatile phase during the early Solar System, or the distance at which that phase can condense into liquid form and resist further migration outward by the solar wind [143,144]. The abundance of water, ammonia, and methane ices are relatively low and dependent on regional conditions in the inner Solar System and more common from the Main Asteroid Belt outwards (Table 2).

Table 2. The surface minerals and ice surface compositions of major rocky bodies in the Solar System.

\begin{tabular}{|c|c|c|c|}
\hline Planetary Body & Major Surface Minerals & Major Ices & References \\
\hline Mercury & $\begin{array}{l}\text { Plagioclase, olivine, pyroxene, } \\
\text { sulfide, graphite }\end{array}$ & Water & [145-149] \\
\hline Venus & $\begin{array}{l}\text { Theorized: Olivine, pyroxene, sulfide, } \\
\text { Fe oxides, carbonates, ilmenite, sulfate }\end{array}$ & None identified to date & {$[150,151]$} \\
\hline Earth & $\begin{array}{c}\text { Olivine, pyroxene, plagioclase, } \\
\text { anorthite, quartz, Ca carbonate, } \\
\text { phyllosilicates, Fe oxides }\end{array}$ & Water, lesser methane & [152-155] \\
\hline Moon & $\begin{array}{l}\text { Anorthite, plagioclase, pyroxene, } \\
\text { olivine, ilmenite }\end{array}$ & Water & {$[146,156,157]$} \\
\hline Mars & $\begin{array}{l}\text { Olivine, pyroxene, phyllosilicates, } \\
\text { sulfates, Fe oxides }\end{array}$ & Water, $\mathrm{CO}_{2}$, possibly methane & {$[146,158-161]$} \\
\hline $\begin{array}{l}\text { Asteroids, moons, } \\
\text { and dwarf planets }\end{array}$ & $\begin{array}{l}\text { Olivine, pyroxene, phyllosilicates, } \\
\text { carbonates, Fe oxides }\end{array}$ & $\begin{array}{l}\text { Water, methane, nitrogen, } \\
\qquad \mathrm{CO}_{2}, \mathrm{CO}\end{array}$ & [162-166] \\
\hline
\end{tabular}

Available surface minerals could have affected prebiotic chemistry in ways that are discernible from mineral records visible today. Because of their long-form structural repetition, available cations, and reactivity, many mineral structures have long been hypothesized to be important in prebiotic chemistry and possible emergence of life $[167,168]$. Indeed, mineral deposits control the availability of non-volatile bio-essential elements, so distinguishing planetary surface mineral deposits is critical to the question of habitability and preservation in the Solar System [168].

Clay minerals are a commonly cited class of minerals to be relevant to prebiotic chemistry, e.g., montmorillonite is found in carbonaceous chondrite meteorites $[169,170]$. $\mathrm{Fe} / \mathrm{Mg}$-clays are of particular interest when constraining planetary habitability, as they tend to be formed in alkaline, reducing environments that some studies propose are favorable for the transition from prebiotic to biotic activity [171-176], and may have even had a role in the origins of life on Earth [177]. The small particle size of clays could have concentrated and protected organic molecules from photolysis [178]. Studies have also suggested that amino acids could be polymerized in aqueous solution in the presence of clay minerals, e.g., montmorillonite [179]. Illite can promote chain elongation of amino 
acids [180]. Hydrotalcite can serve to concentrate glycolaldehyde phosphate from dilute solution and thus catalyze condensation of the carbohydrate subunits [181].

Only some of these planetary minerals can structurally have different chiral forms. Mineral chirality is difficult to observe using the surface characterization methods traditional in planetary science, but as mineral chirality could have affected origins of life processes, a review of mineral chirality and how it intersects with prebiotic chemistry is of growing importance.

\section{Mineral Chirality}

Chirality is not just limited to organics; minerals can be intrinsically chiral (e.g., $\mathrm{L}$ versus D quartz), be overall achiral, but have chiral faces (e.g., calcite), have local chiral sites, or build chiral macromolecular structures (e.g., carbonate toroidal super structures [182] or spiraling of gastropod shells $[183,184])$. Mineral chirality is important to understand because interactions of organic molecules with mineral surfaces may also confer a degree of chiral selectivity in abiotic planetary systems.

\subsection{Enantiomorphic Minerals}

Mineral crystals are built from repeated translations of "unit cells," or the smallest repeating pattern of atoms that reflects the symmetry and structure of the entire crystal. Unit cells are classified into one of six geometric crystal families, which groups crystals based on a combination of the unit cell's shape (i.e., lattice structure) and the required symmetry of their point groups (i.e., a group that describes the symmetry operations under which the unit cell is invariant). Within each crystal family, the specific geometry and symmetry of a unit cell can be more specifically classified into space groups; thus, every mineral belongs to one of 230 space groups. The space group describes both the specific translational symmetry of the unit cell (i.e., the Bravais lattice, screw axis, and glide planes) and the point group symmetry operations (reflection, rotation, inversion, or rotoinversion). Minerals whose unit cells cannot be superimposed onto their mirror image are considered enantiomorphic (i.e., chiral); thus, asymmetry can be deduced based on the space group of the mineral. In other words, specific space groups are chiral and can be used to identify chiral minerals. Of the 230 possible space groups, 64 (belonging to 11 of the 32 crystal point groups) are chiral (Table 3). A full list of chiral minerals (as identified by their space group) and their chemical formula have been compiled (Table S1, Supplementary Material) using the mineral database Mindat. Notably, mineral enantiomorphs do not belong to the same space group.

As larger crystal structures reflect the inherent geometry and symmetry of the unit cell, minerals that are chiral at the unit cell will have crystal faces that are also chiral. Chiral minerals are composed of chiral unit cells which themselves may be made up of achiral subunits. For example, one of the most commonly discussed chiral minerals, $\alpha$-quartz, is composed of repeated molecules of achiral silicate $\left(\mathrm{SiO}_{4}\right)$. It is the arrangement of the silicate molecules into left- or right-handed helices that give quartz its chirality (as evidenced by its unit cell and crystal lattice in Figure 3). Consequently, dissolution of chiral minerals will often result in achiral mixtures (e.g., dissolved achiral silicate molecules).

\subsection{Achiral Minerals with Chiral Faces}

Depending on the environmental conditions, minerals can form different crystal habits, some of which may have faces that are chiral [185] (Table 4). For example, calcite $\left(\mathrm{CaCO}_{3}\right)$ is centrosymmetric (i.e., its unit cell is achiral), but it can take on many different forms, the most abundant being scalenohedral (e.g., dog-tooth spar) or rhombohedral; the former has chiral faces $\left\{\begin{array}{lll}2 & 1 & 4\end{array}\right\}$ while the latter has faces $\left\{\begin{array}{lll}1 & 0 & 4\end{array}\right\}$ that are achiral [186] (Figure 3). The scalenohedral form comes in pairs of chiral faces, but the overall unit cell remains achiral. This is notably distinct from chiral minerals whose faces are not only all chiral, but are either entirely all L or D forms (rather than having a crystal with both), except for crystals which are internally twinned via the Brazil law. Crystal twinning occurs when a crystal is 
subjected to an environmental change (usually temperature or pressure) that results in the growth of a different crystal onto a face of the first. This is especially common for minerals that have polymorphs that are favored under different geochemical conditions. There are different types of twinning; for chiral minerals, the most relevant is the Brazil law twin, which combines right- and left-handed crystals within a growing crystal structure. For quartz, Brazil law twinning is common and is almost never reflected in the surface crystal morphology; thus, quartz minerals may appear chiral, but are internally twinned and are thus racemic [187]. Given the potential for an achiral mineral to possess a racemic interior, together with the fact that achiral crystals can possess a set of chiral faces, it has been advocated that chirality studies involving minerals should avoid powdering the mineral of interest (as chirality information is then lost) [188]. Instead, studies should focus on organic adsorption of chiral species on preserved faces of crystals, whose chirality can be checked against the resulting ee (if any).

\subsection{Local Chiral Sites}

In the natural world, minerals usually form imperfect crystals; that is, their internal structure does not perfectly match that expected from the unit cell. The interruption of the ideal crystal lattice (i.e., crystal defects) can yield local chiral sites on an otherwise achiral mineral or crystal face [185]. Crystal defects are categorized into three groups: point (e.g., vacancies, irregular placement of atoms, substitutions, or kinks), linear (e.g., steps), and plane (e.g., terraces). As organics adsorb most efficiently at defect sites (ledges, kinks, and surface vacancies $>$ terraces), these local chiral centers could provide an efficient means to generate local regions of organic ee [186]. Structural defects are an inherent part of crystal growth; thus, if organics bind to the growing mineral during this process, they can have an impact on the final crystal structure, including the chirality of the mineral $[28,182,189]$. As every crystal structure will have some crystal defects, local mineral chiral sites may play a bigger role in influencing organic chirality than the inherent chirality of minerals as a whole. In addition to promoting organic adsorption, defect sites are also reactive [190] and can thus serve as an efficient site for further organic reactivity involving the preferentially adsorbed enantiomer.

In addition to local chiral sites existing at mineral surfaces due to structural defects, chiral selectivity can be induced as a result of cooperative effects between chiral organics and the (in)organic analytes that have previously adsorbed at the mineral surface or intercalated (i.e., inserted) between mineral layers. For example, the initial adsorption of one organic enantiomer at the surface could bind in such a way that its orientation further promoted the adsorption of that particular enantiomer. On the other hand, intercalation of other ions/organics could lead to chiral orientations between mineral layers. There are several mechanisms that can induce chirality between layers, including partial ion-exchange (e.g., $\mathrm{Al}^{3+}$ for $\mathrm{Mg}^{2+}$ ) which could lead to multiple sites between any mineral layers with different ions that are of various size and possess different binding capabilities for organic enantiomers; alternatively, ion-exchange could also result in site vacancies that are chiral [191]. Another means of inducing chiral selectivity between mineral sheets is due to differences in the binding orientation and exchange kinetics between the mineral layers and organic enantiomers [192,193]. For instance, a study on the intercalation of L- and D- histidine within vermiculite clay found that the two enantiomers had different effects on the osmotic swelling and d-spacing between the mineral layers [194,195].

\subsection{Factors That Influence a Mineral's Degree of Enantioselectivity}

There are inherent factors that influence the degree to which chiral minerals (either via their internal structure or having chiral faces) can drive organic ee: the most notable being the degree to which the mineral enantiomers are structurally different (i.e., the chiral index; [196]) and the degree to which organic enantiomers are sorbed to the mineral surface e.g., ref. [197]. 
Table 3. A list of chiral minerals organized by their crystal system, class, and space group.

\begin{tabular}{|c|c|c|c|c|c|c|}
\hline Crystal Family & Crystal Class Number & Crystal Class & Space Group & Example Mineral & Formula & Category \\
\hline Triclinic & 1 & Pedial & P1 & $\begin{array}{c}\text { Kaolinite } \\
\text { Amesite } \\
\text { Nordstrandite }\end{array}$ & $\begin{array}{c}\mathrm{Al}_{2}\left(\mathrm{Si}_{2} \mathrm{O}_{5}\right)(\mathrm{OH})_{4} \\
\mathrm{Mg}_{2} \mathrm{Al}_{2} \mathrm{SiO}_{5}(\mathrm{OH})_{4} \\
\mathrm{Al}(\mathrm{OH})_{3}\end{array}$ & $\begin{array}{c}\text { Phyllosilicate } \\
\text { Phyllosilicate } \\
\text { Metal oxide }\end{array}$ \\
\hline Monoclinic & 2 & Sphenoidal & $\mathrm{P} 2, \mathrm{P} 2{ }_{1}, \mathrm{C} 2$ & $\begin{array}{l}\text { Buddingtonite } \\
\text { Bassanite }\end{array}$ & $\mathrm{NH}_{4} \mathrm{AlSi}_{3} \mathrm{O}_{8} \mathrm{Ca}\left(\mathrm{SO}_{4}\right) \cdot 0.5 \mathrm{H}_{2} \mathrm{O}$ & $\begin{array}{l}\text { Tectosilicate } \\
\text { Sulfate }\end{array}$ \\
\hline Orthorhombic & 222 & Rhombic-disphenoidal & $\begin{array}{c}\mathrm{P} 222, \mathrm{P} 222_{1}, \mathrm{P} 2{ }_{1} 2_{1} 2, \mathrm{P} 2_{1} 2_{1} 2_{1}, \mathrm{C} 222, \mathrm{C} 222_{1}, \mathrm{~F} 222, \mathrm{I} 222, \\
\mathrm{I} 2_{1} 2_{1} 2_{1}\end{array}$ & $\begin{array}{l}\text { Wülfingite } \\
\text { Epsomite } \\
\text { Sanderite } \\
\text { Lecontite } \\
\text { Abuite }\end{array}$ & $\begin{array}{c}\mathrm{Zn}(\mathrm{OH})_{2} \\
\mathrm{MgSO}_{4} \cdot 7 \mathrm{H}_{2} \mathrm{O} \\
\mathrm{MgSO}_{4} \cdot 2 \mathrm{H}_{2} \mathrm{O} \\
\left(\mathrm{NH}_{4}, \mathrm{~K}^{2} \mathrm{NaSO}_{4} \cdot 2 \mathrm{H}_{2} \mathrm{O}\right. \\
\mathrm{CaAl}_{2}\left(\mathrm{PO}_{4}\right)_{2} \mathrm{~F}_{2}\end{array}$ & $\begin{array}{l}\text { Metal oxide } \\
\text { Sulfate } \\
\text { Sulfate } \\
\text { Sulfate } \\
\text { Phosphate }\end{array}$ \\
\hline \multirow[t]{2}{*}{ Tetragonal } & 4 & Tetragonal-pyramidal & $\mathrm{P} 4, \mathrm{P}_{1}, \mathrm{P}_{2}, \mathrm{P}_{3}, \mathrm{I} 4, \mathrm{I}_{1}$ & & & \\
\hline & 422 & Tetragonal-trapezoidal & $\begin{array}{c}\mathrm{P} 422, \mathrm{P} 42_{1} 2, \mathrm{P} 4_{1} 22, \mathrm{P}_{1} 2_{1} 2, \mathrm{P}_{2} 22, \mathrm{P} 4_{2} 2_{1} 2, \mathrm{P}_{3} 22, \\
\mathrm{P} 4_{3} 2_{1} 2, \mathrm{I}_{1} 22, \mathrm{I} 42_{1} 2\end{array}$ & $\begin{array}{l}\text { Cristobalite } \\
\text { Wardite }\end{array}$ & $\begin{array}{c}\mathrm{SiO}_{2} \\
\mathrm{NaAl}_{3}\left(\mathrm{PO}_{4}\right)_{2}(\mathrm{OH})_{4} \cdot 2\left(\mathrm{H}_{2} \mathrm{O}\right) \\
\end{array}$ & $\begin{array}{l}\text { Tectosilicate } \\
\text { Phosphate }\end{array}$ \\
\hline \multirow[t]{6}{*}{ Hexagonal } & 3 & Trigonal-pyramidal & $\mathrm{P} 3, \mathrm{P}_{1}, \mathrm{P} 3_{2}, \mathrm{R} 3$ & Monohydrocalcite & $\mathrm{CaCO}_{3} \cdot \mathrm{H}_{2} \mathrm{O}$ & Carbonate \\
\hline & 32 & Trigonal-trapezohedral & $\mathrm{P} 312, \mathrm{P}_{1} 12, \mathrm{P}_{2} 12 \mathrm{c}, \mathrm{P} 3_{2} 12, \mathrm{P}_{1} 21, \mathrm{P} 3_{2} 21, \mathrm{R} 32$ & $\begin{array}{c}\text { Berlinite } \\
\alpha \text {-D-quartz } \\
\alpha \text {-L-quartz } \\
\text { Antarcticite } \\
\text { Huntite }\end{array}$ & $\begin{array}{c}\mathrm{AlPO}_{4} \\
\mathrm{SiO}_{2} \\
\mathrm{SiO}_{2} \\
\mathrm{CaCl}_{2} \\
\cdot 6 \mathrm{H}_{2} \mathrm{O} \\
\mathrm{Mg}_{3} \mathrm{Ca}_{2}\left(\mathrm{CO}_{3}\right)_{4} \\
\mathrm{SiO}_{2}\end{array}$ & $\begin{array}{c}\text { Phosphate } \\
\text { Tectosilicate } \\
\text { Tectosilicate } \\
\text { Chloride } \\
\text { Carbonate }\end{array}$ \\
\hline & 6 & Hexagonal-pyramidal & $\mathrm{P} 6, \mathrm{P} 6_{1}, \mathrm{P} 6_{2}, \mathrm{P} 6_{3}, \mathrm{P} 6_{4}, \mathrm{P} 6_{5}$ & $\begin{array}{l}\text { Trinepheline } \\
\text { Kellyite } \\
\text { Nagelschmidtite }\end{array}$ & $\begin{array}{c}\mathrm{SiO}_{2} \\
\mathrm{KAlSiO}_{4} \\
\mathrm{Mg}_{4} \mathrm{Al}_{2}(\mathrm{OH})_{12}\left(\mathrm{CO}_{3}\right) \cdot 3 \\
\mathrm{H}_{2} \mathrm{O}\end{array}$ & $\begin{array}{l}\text { Silicate } \\
\text { Phyllosilicate } \\
\text { Neosilicate }\end{array}$ \\
\hline & & & & $\beta$-D-quartz & $(\mathrm{Ni}, \mathrm{Fe})_{4} \mathrm{P}$ & Tectosilicate \\
\hline & 622 & Hexagonal-trapezohedral & $\mathrm{P} 622, \mathrm{P}_{1} 22, \mathrm{P}_{2} 22, \mathrm{P}_{3} 22, \mathrm{P}_{4} 22, \mathrm{P} 6_{5} 22$ & $\begin{array}{l}\beta \text {-L-quartz } \\
\text { Kalsilite }\end{array}$ & $\begin{array}{l}\mathrm{MnSi} \\
\mathrm{FeSi}\end{array}$ & $\begin{array}{l}\text { Tectosilicate } \\
\text { Kalsilite }\end{array}$ \\
\hline & & & & Quintinite & $\mathrm{K}_{2} \mathrm{Mg}_{2}\left(\mathrm{SO}_{4}\right)_{3}$ & Carbonate \\
\hline \multirow{4}{*}{ Cubic } & & & & Melliniite & \multirow{4}{*}{$\mathrm{NH}_{4} \mathrm{Cl} \gamma-\mathrm{Fe}_{2} \mathrm{O}_{3}$} & Phosphide \\
\hline & 23 & Tetaroidal & $\mathrm{P} 23, \mathrm{P} 2{ }_{1} 3, \mathrm{~F} 23, \mathrm{I} 23, \mathrm{I}_{1} 3$ & Brownleeite & & $\begin{array}{l}\text { Silicide } \\
\text { Silicide }\end{array}$ \\
\hline & & & & Langbeinite & & Sulfate \\
\hline & 432 & Gyroidal & $\mathrm{P} 423, \mathrm{P}_{2} 32, \mathrm{P} 4_{3} 32, \mathrm{P} 4_{1} 32, \mathrm{~F} 432, \mathrm{~F} 432, \mathrm{I} 432, \mathrm{I}_{1} 32$ & $\begin{array}{l}\text { Salammoniac } \\
\text { Maghemite }\end{array}$ & & $\begin{array}{l}\text { Chloride } \\
\text { Metal oxide }\end{array}$ \\
\hline
\end{tabular}


Table 4. A list of some achiral minerals with chiral faces.

\begin{tabular}{cccc}
\hline Mineral & Formula & Face $\{$ Miller Index $\}$ & Category \\
\hline Calcite & $\mathrm{CaCO}_{3}$ & $(214)$ & Carbonate \\
Gypsum & $\mathrm{CaSO}_{4} \cdot 2 \mathrm{H}_{2} \mathrm{O}$ & $(110),(111)$ & Sulfate \\
Olivine & $\left(\mathrm{Mg}^{2+}, \mathrm{Fe}^{2+}\right)_{2} \mathrm{SiO}_{4}$ & $(111)$ & Silicate \\
Clinopyroxene & $(\mathrm{Ca}, \mathrm{Mg}, \mathrm{Fe}, \mathrm{Na})(\mathrm{Mg}, \mathrm{Fe}, \mathrm{Al})(\mathrm{Si}, \mathrm{Al})_{2} \mathrm{O}_{6}$ & $(110),(111)$ & $\mathrm{Oxide}$ \\
Clinoamphibole: e.g., hornblende & $(\mathrm{Ca}, \mathrm{Na})_{2-3}(\mathrm{Mg}, \mathrm{Fe}, \mathrm{Al})_{5}(\mathrm{Al}, \mathrm{Si})_{8} \mathrm{O}_{22}(\mathrm{OH}, \mathrm{F})_{2}$ & $(110),(011)$ & Inosilicate \\
\hline
\end{tabular}

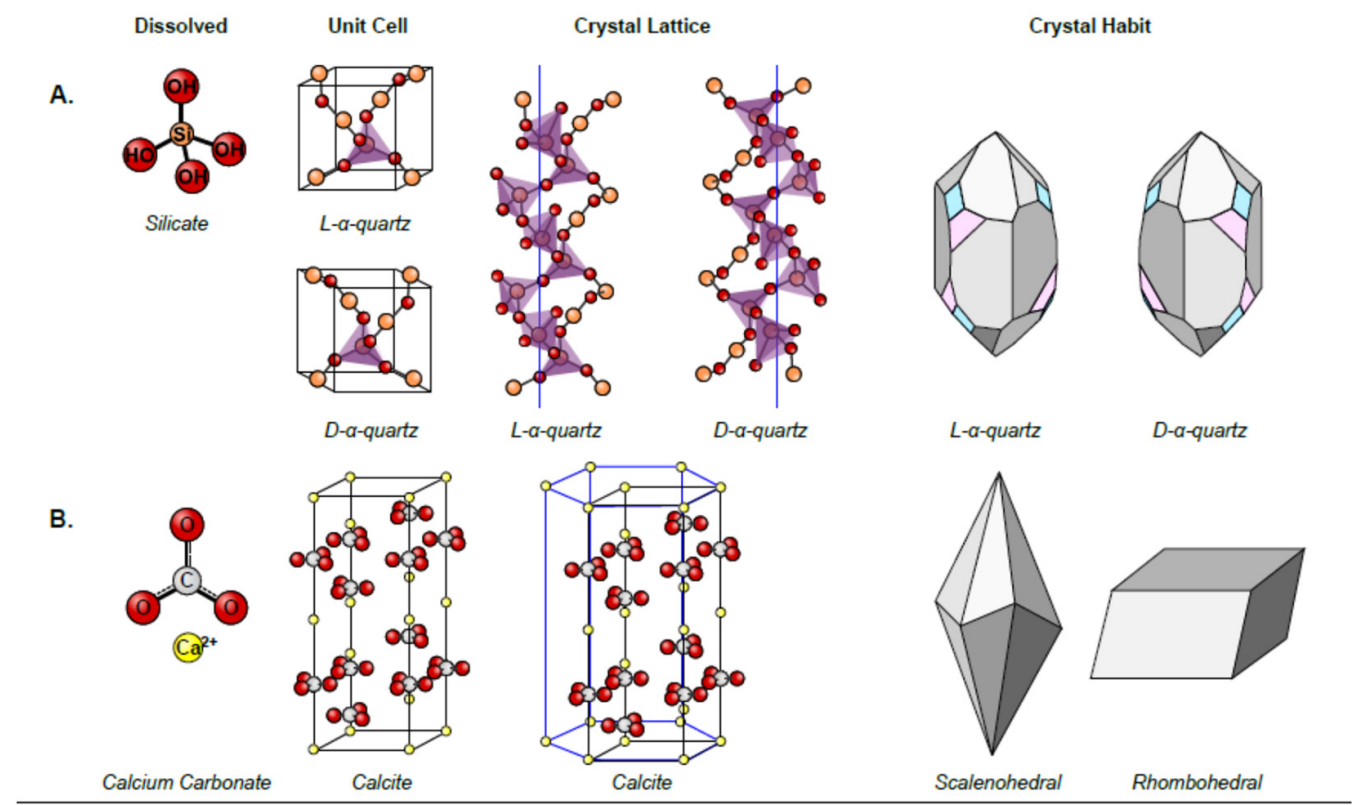

C. Local defects on rhombohedral calcite

D. Macromolecular chiral structure
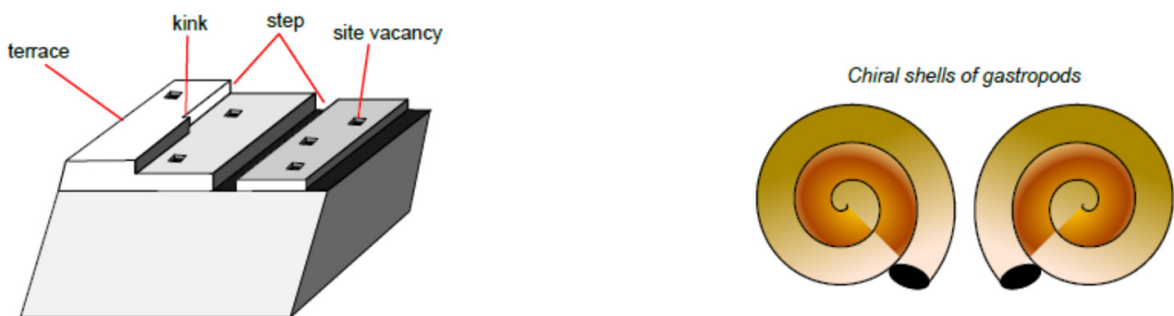

Figure 3. Summary of the variations of chirality of mineral crystals. (A) Inherent chirality, as observed in the unit cell with quartz as an example. (B) Chiral faces of achiral minerals with calcite as the example: the unit cell is achiral as is the crystal lattice; however, the crystal habit can have chiral faces, as observed with the scalenohedral habit, and the rhombohedral habit has no chiral faces. (C) Natural minerals have local defects that can result in local chiral centers. Shown are defects typical of a growing crystal structure. (D) Macromolecular mineralogical structures can have chirality. Often, precipitated shells of biological organisms have a chiral structure, such as the gastropod shells drawn here.

A chiral index: The degree to which enantiomorphic minerals differ from their mirror counterpart is predicted to impact their organic enantioselective potential and can be described mathematically using the chiral index (a term coined by [196]). Downs and Hazen 2004 proposed a methodology to calculate the chiral index of any mineral, and suggested that this measurement could be used to identify minerals with strong potential for driving organic ee. The basis of their calculations follows the logic used to quantify a similar measurement, the distortion index [198], which quantifies the deviation of a periodic arrangement of atoms from its perfect crystal structure due to imperfections. The chiral 
index, instead, quantifies the degree of misfit between any two chiral faces or structures. This measurement predicts the potential for mineral faces (e.g., those of calcite) or inherent structure (e.g., quartz) to drive organic ee via mineral-organic interactions. Using this approach, ref. [196] compared the enantioselective potential of the faces of several minerals (calcite, diopside, orthoclase, quartz, and copper) and discovered that the calcite $\left\{\begin{array}{lll}2 & 1 & 4\end{array}\right\}$ face, and to a lesser extent diopside and copper, had a higher chiral index (and thus larger enantioselective potential) than the mineral with inherent chiral symmetry-quartz. Although this was a computational study, their results are consistent with experimental work that has found that the calcite $\left\{\begin{array}{lll}2 & 1 & 4\end{array}\right\}$ face results in larger ee from racemic amino acid mixtures $(\sim 10 \%$ chiral excess $)$ than quartz $(\sim 1 \%$ chiral excess; $[187,196])$. Note that earlier studies may have underestimated the degree of chiral selection on quartz surfaces due to internal Brazil twinning that results in internally racemic quartz crystals [187,199]; although, studies that took care to work with untwinned quartz crystals still found that the degree of chiral selectivity on quartz is modest at best [200-202].

Downs and Hazen (2004) note that their described chiral index does not necessarily capture the degree to which each mineral can drive organic ee (as there are many factors that can impact mineral-organic interactions). Thus, they suggested two additional chiral indices to consider: one that describes the degree of fit between organic enantiomers onto a mineral surface, or a more general approach based on three-point interactions calculated using triangles formed by nearest-neighbor atoms on the mineral surface. To our knowledge, a follow-up study to calculate these proposed indices has not been published, nor have there been any efforts to apply the chiral index as previously described [196] to other chiral minerals.

Mineral-organic interactions: Chiral organic molecules have mostly identical physical and chemical properties; however, the difference in their structural arrangement imparts differences in their degree of interaction with any chiral selector, whether it be organic (e.g., proteins) or inorganic (e.g., minerals). Chiral selectors are inorganic or organic materials that form diastereoisomeric complexes with the chiral analyte. Notably, not all chiral organic molecules will form diastereoisomeric complexes with chiral surfaces on minerals; thus, chiral materials are not always enantioselective. Previous work has demonstrated that there must be a minimum of three noncollinear points of interaction between a chiral analyte and chiral selector for there to be any enantioselectivity; this is also referred to as the threepoint minimum interaction model [203-205]. This model is consistent with experimental studies, which found that chiral surfaces of calcite are enantioselective for only certain amino acids (e.g., aspartate), but not others (e.g., alanine, valine, lysine) $[186,188,206]$. Accordingly, computational studies modeling the interactions of alanine and aspartate with calcite surfaces revealed that aspartate was bound to calcite at three binding sites whereas alanine was only bound at two. While the three-point model is a good starting point for assessing the potential enantioselectivity in the binding of molecules, it should be noted that the model has faced scrutiny $[207,208]$, as it has been demonstrated that sometimes four points of interaction are needed [208]; alternatively, with aromatic organic molecules, a pseudo-two-point interaction may suffice [207].

If we were to develop an equation that properly predicts the enantioselective potential of a mineral in any given environment, the chiral index [196], which describes the mismatch between any two surface enantiomorphs of a mineral, would only represent one variable. Some of the remaining variables would have to capture some information regarding the chiral analyte of interest, including how it interacts with the mineral surface. As previously discussed, generally three points of interaction are required between the mineral and organic analyte for the mineral to impart chiral selectivity onto the system. At these three points, any molecular interaction will suffice, although the type of molecular interaction will impact the degree to which the mineral can drive organic ee and under which environmental conditions it can do so. Mineral-organic interactions can involve bonding and/or nonbonding interactions (i.e., covalent, H-bonds, steric hindrance, pi-pi, ion-dipole, dipole-dipole, dipole-induced-dipole, and London dispersion or van der Waals, 
see [209] for a review). The relative strength of these interactions (which is dependent on type and environment) impacts the enantioselectivity of the mineral of interest (with stronger bonds increasing enantioselectivity). Thus, an idealized equation for describing the enantioselectivity of a mineral would also include variables that describe the bond type between each organic-mineral interaction, the surrounding environmental conditions $(\mathrm{pH}$, temperature, and salinity), and how the organic analyte and mineral surface are expected to change with environmental parameters (e.g., $\mathrm{pK}_{\mathrm{a}}$ of the organic, point of zero charge for the mineral).

\subsection{Mineral-Organic Interactions for Driving Enantiomeric Excess}

Minerals can drive enantiomeric excess (ee) via selective adsorption that facilitates (1) the production of one enantiomer of a chiral compound; (2) the formation of homochiral polymers (e.g., by facilitating polymerization of L-amino acids); (3) solutions with ee (e.g., preferential adsorption of L-sugars generates solutions enriched in R-sugars); and/or (4) the preferential preservation (or degradation) of the adsorbed enantiomer. Notably, the number of studies that have investigated the influence of chiral mineral surfaces on driving ee of organic enantiomers remains limited. In general, these studies have found that minerals only induce minimal to modest enantiomeric selectivity [177,186,200,201,210]. Although this may result in significant ee over geologic timescales, as chiral molecules can racemize over time, this may not provide an adequate solution ([211] and references therein). One potential resolution to this conundrum are autocatalytic processes, wherein mineral-organic interactions yield conditions that promote enantioselectivity, and the resulting products in turn further promote enantioselectivity. One of the most notable autocatalytic reactions in organic synthesis is the Soai reaction (Table 1), which produces a near enantiopure solution (>99.5\% ee) in high yields (>99\%) using 3-pyridylalkanol as an asymmetric autocatalyst [26]. As summarized in the review by [212], the organic autocatalyst of the Soai reaction can be successfully substituted for more prebiotically relevant catalysts, including the minerals quartz, gypsum, retgersite, cinnabar, sodium chlorate, and sodium borate-all of which generated near enantiopure solutions in high yields [27,213-217]. These results demonstrate how minerals can induce significant enantioselectivity when subjected to asymmetric autocatalytic reactions.

Autocatalytic systems can also include the precipitation of enantiopure minerals and/or organic crystals as well as formation of surface defects that further promote mineral-organic enantiospecific reactions. These reactions warrant further studies, given that minor ee of either the organic or mineral reagent could lead to near enantiopure solutions or crystals. In fact, even racemic or achiral solutions can produce enantiopure crystals. This was observed in [218], which found that stirred solutions of sodium chlorate (which is achiral) precipitated chiral crystals, all of which had the same handedness; repeated experiments found that the system would consistently produce crystals of either D or L handedness, although which enantiomorph (D or L) precipitated varied between reactions. Subsequent studies elucidated the mechanism at work: the stirring of the solution promoted rapid shearing of the initial crystal that precipitated $[15,219]$. Thus, if the initial crystal precipitate was of the $\mathrm{D}$ form, then shearing (due to mixing) would rapidly break apart the D crystal, producing many smaller D crystals that could then act as nucleation centers for further precipitation of the D enantiomorph. For such reactions, an initial enantiomeric seed was not added to the system, but was a product of random chance.

Although systems that generate enantiopure products from achiral mixtures may have been relevant for the origins of homochiral polymers in biochemistry, the fact that they generate either D or L forms only by chance suggests that overall such systems may have canceled each other out. Alternatively, systems containing a slight excess of an organic and/or mineral enantiomer may, via positive feedback reactions, result in systems with significant ee. One example of such chemistry is that of D and L precipitating tyrosine [220]. Originally, the authors found that D-tyrosine crystallized out of solution much faster than L-tyrosine. These results were replicated by [221] when they used D/L-tyrosine 
from the same source as [220]; however, when different tyrosine sources were used, the results were not replicated. Accordingly, when [222] repeated the study, they found that D/L-tyrosine had different solubilities only when the prepared solutions were not passed through a $0.2 \mu \mathrm{m}$ filter; when the solutions were filtered, the effect was not observed. Both [221] and [222] concluded that the discrepancy of D/L-tyrosine solubility was due to different contaminants, such as fungal spores being present in the D/L-tyrosine powders purchased from various vendors. The authors of [223] contested this interpretation, arguing that the solubility differences were due to the parity violation energy difference between enantiomers (a topic which falls outside of the scope of this review).

If trace contaminants are responsible for the apparent differences in enantiomeric solubility of tyrosine, then a slight excess of a mineral and/or organic enantiomer could drive the precipitation of chiral structures, such as D-tyrosine organic crystals. Alternatively, minor seeds of an organic enantiomer could result in the precipitation of chiral mineral structures, which in turn facilitate the adsorption of an organic enantiomer. For example, $\mathrm{D} / \mathrm{L}$ enantiomers of aspartic acid or glutamic acid present in solutions undergoing $\mathrm{CaCO}_{3}$ precipitation, induced the formation of macro mineral-organic chiral structures [182]. The resulting chiral structure could then promote the adsorption of the seed enantiomer. On the other hand, the presence of organic acids with minor ee can promote the dissolution of the chiral mineral surfaces to which it binds, producing step-like features on the surface [224]. These steps can then enhance organic adsorption onto the corresponding chiral surface, consequently promoting enantioselective adsorption onto that surface and driving ee of the remaining solution [186].

\subsection{Future Directions}

There are many minerals that are inherently chiral (Tables 3 and S1); however, their prevalence on early Earth or other planetary bodies remains understudied and uncertain. Moreover, widespread conditions favoring the formation of a particular mineral enantiomorph seem unlikely. For example, on Earth, the two quartz enantiomorphs are equally abundant and are often found within the same crystal (i.e., the crystal is internally twinned and thus racemic) $[225,226]$. Investigations into conditions that could potentially favor the crystallization or preservation of one mineral crystal enantiomorph, over the other, remains uncertain and largely unexplored. One potential research avenue to explore this question would be to computationally explore whether dissolved achiral contaminants ever preferentially adsorb onto only one of two chiral mineral surfaces, thus promoting the dissolution or precipitation of a particular chiral surface. Alternatively, circularly polarized light or spin polarized electrons emitted during beta decay of radioactive nuclei, both of which are proposed as a mechanism for ee of L-amino acids in meteorites [227-229], see 14 and references therein, could also impart chirality onto precipitating minerals or preferentially alter the surface of achiral or chiral minerals, producing surface defects that could either serve as additional chiral sites and/or further promote organic adsorption and reactivity [186,190,230-235]. These astrophysical processes could thus serve as a means for generating inorganic chiral seeds that could subsequently trigger asymmetric autocatalytic systems, as described in Section 6.5.

Prebiotic investigations of the stereoselective effects minerals impart on organic systems and vice versa is relatively limited, with most organic-mineral studies focusing on the adsorption of amino acids on montmorillonite or other clays see [236] and references therein. However, as shown in Tables 3, 4 and S1, there are many minerals that are either inherently chiral or possess chiral faces that are geologically or chemically relevant; even achiral minerals with achiral faces can possess local chiral sites at the surface or between layers. The most notable minerals with chiral surfaces are those of evaporites, which are especially interesting considering their prevalence on the Martian surface [237,238]. Minerals with inherent chirality and planetary relevance include some phyllosilicates (e.g., kaolinite, a common crustal mineral identified on Mars [239-241]), zeolites (which can act as prebiotic catalysts and has been detected on Mars, [242-245], sulfates (e.g., epsomite, 
bassanite, and sanderite, which are present on the Martian surface and can preserve biosignatures $[238,240,246-248])$, sal-ammoniac $\left(\mathrm{NH}_{4} \mathrm{Cl}\right)$, which has been found on the surface of Ceres $[249,250]$, maghemite (a common Fe oxyhydroxide that can form from weathering of magnetite and is also likely on Mars [251-254]), phosphates (which could act as a source for organic phosphorylation of chiral compounds), and borates (which are the likely form of boron detected on the Martian surface and have been demonstrated to selectively promote the preservation of ribose [255-260]). Given the planetary and prebiotic relevance of such chiral minerals, additional investigations exploring their enantioselective potential within prebiotic systems are warranted.

As previously discussed, the enantioselective potential of any chiral surface is dependent on its local environment ( $\mathrm{pH}$, temperature, salinity, and pressure), the organic analyte $\left(\mathrm{pK}_{\mathrm{a}}\right.$, and number and types of bonds with the mineral), and its inherent physical properties (point of zero valent charge and degree of mismatch between its two enantiomorphs). The authors of [196] calculated a chiral index for several chiral minerals based on the degree of mismatch between their enantiomorphs, and suggested that other chiral indices could be calculated based on the three-point interaction model and the differences between the binding sites of two organic enantiomers onto any chiral surface. This original study was published in 2004, and since then molecular modeling approaches have vastly improved and now provide a facile means to obtain the geometry of the available binding sites on any mineral surface and the resulting geometry and bond energies for each of the mineral-organic interactions. These variables could then be used as inputs to calculate a better description of the enantioselective potential of a wide-range of minerals under various geochemical conditions. Such studies are warranted, as obtaining enantiopure minerals is challenging (as they may look enantiopure on the outside, but possess internal twinning) and that natural minerals also possess organic contaminants, many of which may be biological and thus have their own asymmetry that could influence the reaction system being studied. In sum, molecular modeling can be a boon to prebiotic studies of ee, as it can be leveraged to systematically evaluate a wide range of minerals and organic-mineral interactions under various geochemical conditions and thus help shed light onto which chiral minerals and mineral surfaces warrant further experimental study.

\section{Alteration during Geochemical Processes}

\subsection{Terrestrial Geochemical Alteration and the Preservation of Organics}

If one were to order the classes of organics based on preservation potential and biological specificity, there would be an inverse relationship [261]. While DNA, RNA, and proteins can specifically fingerprint their biological source, they are also the most labile organic compound class [262,263]. Lipids, on the other hand, while present in many living organisms and can have high biological specificity, typically exhibit a broad range of sources. Lipids and their hydrocarbon derivatives are the most recalcitrant class of organic compound; therefore, over geologic time and under suitable conditions, they will be the most likely organic remnants [264,265].

There are some asymmetric reactions that are involved in the synthesis of (phospho) lipid membrane molecules (e.g., [266-269]). Although lipids are considered the most taphonomically robust to degradation and alteration over long geologic timescales, they are not immediately associated with research into chiral organic compounds. Lipids possess chirality in the way that amino acids and sugars do, and commonly have multiple stereogenic centers leading to many different potential stereoisomers (discussed below). To understand how organics and biosignatures can be detected in samples, it is important to recognize the reactions and conditions that affect their sequestration and preservation. The following sections will describe the processes by which organic compounds are sequestered and preserved in the rock record and the ways in which chiral configurations can be affected by geological alteration. 


\subsection{Formation of Insoluble Macromolecular Organic Matter}

On Earth, an average of $>99 \%$ of organic matter (OM) produced from photosynthesis is rapidly remineralized during early diagenesis by biochemical degradation [270]. As OM is sequestered and buried in the sedimentary record, the physical and chemical processes known as diagenesis, catagenesis, and metagenesis take place. Diagenesis occurs during shallow burial at low temperatures, and physical and chemical processes continue to accumulate a small fraction of degradation-resistant OM, which is polymerized and crosslinked to form a biomacromolecular matrix, known as kerogen. During this process, many lipid components, which can act as biosignatures and are highly resistant to biochemical degradation, are bound within the insoluble organic matter (IOM) matrix [271]. Despite the rapid overturn of OM during the early stages of deposition [272] and the specific environmental conditions required for organic preservation [273], kerogen-like macromolecular OM is recovered even during this early phase [274,275] with the proportion of organics bound into the matrix increasing over geological time [275-277]. Catagenesis involves increases in burial temperature and depth over time with a significant component of heating that induces the cracking of the macromolecular structure to liberate shorter-chain hydrocarbons [278]. Metagenesis occurs at higher burial temperatures (low grade metamorphic temperatures above $200{ }^{\circ} \mathrm{C}$ ) and depths and involves the cracking of residual hydrocarbon bitumen into dry gas (>98\% methane) and solidified pyrobitumen [273,279].

Although the definition of kerogen has evolved over time, traditionally it is operationally defined as the solid residue that remains after OM has been extracted with organic solvents [280-282]. For mature, consolidated kerogens, it typically also excludes the aciddigestible and hydrolyzable component containing organics that are associated with the mineral matrix [281]. The remainder of sedimentary OM is defined as the component that is readily extractable with organic solvents, known as bitumen. The components of kerogen consist of the sum of the simple organic precursor molecules that were sequestered into the macromolecular structure during sedimentary diagenetic and catagenetic processes.

Mineral substrates and matrices are critically important to the preservation of organic compounds [282-284], as they provide stability and protection to organics not only during deposition and sedimentary alteration, but also against harsh environmental conditions, such as radiation (e.g., [285]). The kerogen macromolecular matrix provides long-term preservation of organics by protecting bound molecules from oxidation and degradation [286]. Kerogen is considered an immobile solid matrix; molecules linked within it were deposited synchronously with the host sedimentary rock. Bound lipids released from kerogen are much less prone to organic contamination from migrating fluids relative to their solvent extractable counterparts [287].

Kerogen is the largest sink of organic carbon on Earth [288] and expected to be the dominant mass fraction of preserved organic matter on other planetary bodies [21,289]. Post-depositional alteration processes, such as the binding of organics, are affected by steric hindrance, especially as the kerogen evolves and becomes more structurally and chemically complex. Hence, stereochemistry is an important consideration for the studies of bound and released organics from mineral and organic matrices. Utilizing techniques that release organic constituents either thermolytically (e.g., heating through pyrolysis) or chemolytically (e.g., selective chemical degradation through chemolysis), significantly enhances the analysis of kerogen, as both processes release products that are amenable to standard chromatographic resolution [287].

\subsection{Stereochemistry of Lipids in Kerogen}

The stereochemistry of the organic compounds, specifically the ratio of isomers that are released through various experimental methods, can reveal the thermal maturity conditions during sequestration. An example comes from common microbial cellular membrane lipids, steroids and hopanoids, which are polycyclic biomarker precursors derived primarily from eukaryotes and bacteria, respectively [278]. In the specific case of steroids, the $C_{27}$ steroid 
(cholesterol) possesses eight asymmetric carbons in its structure, at C-3, 8, 9, 10, 13, 14, 17, and 20 [290], giving rise to the possibility of numerous stereochemical configurations (Figure 4).

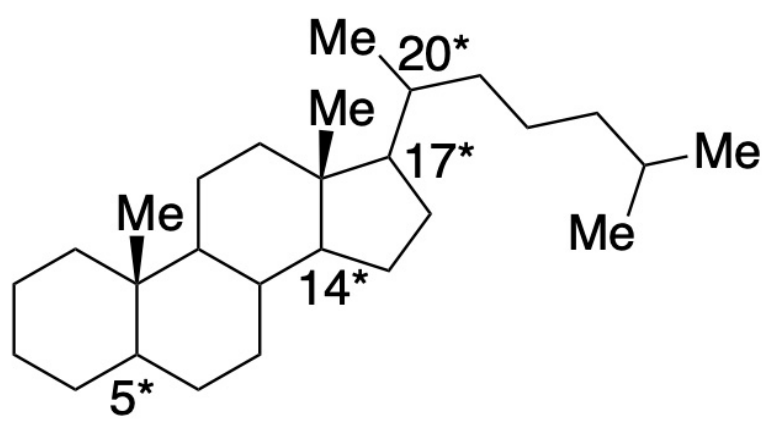

Figure 4. Structure of the $\mathrm{C}_{27}$ sterane, cholestane. The asterisk $\left.{ }^{*}\right)$ at $\mathrm{C}-5, \mathrm{C}-14, \mathrm{C}-17$, and $\mathrm{C}-20$ indicate where a $\mathrm{H}$ can be in the $\alpha$ - or $\beta$-configuration, and the carbon at $\mathrm{C}-20$ can be the $\mathrm{R}$ or $\mathrm{S}$ enantiomer. The $\mathrm{R}$ enantiomer is the biological form, whereas the $\mathrm{S}$ enantiomer is the geologically stable form.

However, only one biological isomer of cholesterol exists, due to the high specificity of steroid biosynthesis [291]. The stereochemical configuration of immature/biologicallyinherited steroids and hopanoids as their hydrocarbon equivalents are $20 \mathrm{R}-5 \alpha / \beta(\mathrm{H})$, $14 \alpha(\mathrm{H}), 17 \alpha(\mathrm{H})$-cholestane $\left(\mathrm{C}_{27}\right.$ sterane), and $17 \beta(\mathrm{H}), 21 \beta(\mathrm{H})$-hopane $\left(\mathrm{C}_{30}\right.$ hopane), respectively. These stereochemical configurations are thermally unstable and they isomerize to the stable forms of $20 S-5 \alpha(\mathrm{H}), 14 \beta(\mathrm{H}), 17 \beta(\mathrm{H})$-cholestane for steranes and $17 \alpha(\mathrm{H})$, $21 \beta(\mathrm{H})$-hopane for hopanes over geological time, as these molecules relieve ring strain and convert from the flat, planar configuration to a bent configuration [278]. During incorporation into kerogen, the asymmetric centers of steranes and hopanes are protected from further thermal isomerization due to steric hindrance within the matrix [278], although the stereospecificity that is highly conserved in the biological form is often lost, with an array of isomers forming [292].

Isomerization, while primarily due to increases in temperature through thermal alteration, could also be catalyzed by clay minerals [293,294]. It has been demonstrated that mineralogy and salinity can affect oil generation kinetics as well as product composition [295,296]. Experimental techniques for fragmenting kerogen into analyzable components, such as pyrolysis assisted by high-pressure hydrogen gas (hydropyrolysis; [287]), releases bound lipids that conserve the original stereochemistry during sequestration [275,297-301]. Thermochemolysis using tetramethylammonium hydroxide (TMAH) compared to standard hydrous pyrolysis demonstrates differences in the stereochemical configuration of released hopanoid products [302], indicating that configurational isomerization (epimerization) occurs during the analytical processes. Future experiments that track structural modifications to stereochemistry associated with simulated alteration and/or maturation processes will be critical to understanding the underlying mechanisms and transformation pathways that prevail during natural processes. They will help better identify and optimize the experimental techniques that should be employed to study these chemical reactions.

\subsection{Compositional Alteration on Other Planetary Bodies}

Meteorites can be classified as chondrites that form from protoplanetary disk material $[303,304]$ and achondrites, which have undergone secondary processes, such as melting and differentiation [305,306]. Chondrite meteorites can be separated into ordinary, carbonaceous, Rumuruti, Kakangari, and enstatite chondrites [304,307]. The carbonaceous chondrite group can be further subdivided into eight main groups (Table 5), based on chemical (mineralogy and isotopic) composition and degree of alteration [308,309]. The six petrologic types describe the extent of aqueous (type 1, 2, and 3) and thermal (types 3 , 4,5 , and 6) alteration, where type 1 is the most aqueously altered and type 6 is the most thermally altered [310]. Similar to how alteration and structural modifications to chemical 
composition can occur to organic matter on Earth, alteration can and does occur during the preservation of carbonaceous OM on other planetary bodies, such as asteroids, comets, and planetary surfaces. These matrices are typically minerals associated with rocky or icy substrates and can occur on the surface regolith or in the parent body interior [311]. Alteration can occur through thermal or aqueous processes, shock wave propagation, and brecciation.

Table 5. Properties of carbonaceous chondrite meteorite groups, including: matrix abundances, chondrule abundances and sizes, refractory component abundances, metallic Fe and Ni abundances, average olivine compositions, and refractory lithophile element abundances. The carbonaceous chondrite meteorite groups are arranged from left to right (CI to CB) in order of decreasing bulk rock oxidation. Table is from [14] and data were compiled from [307,312-314].

\begin{tabular}{|c|c|c|c|c|c|c|c|c|}
\hline Petrologic Type & CI & $\mathbf{C M}$ & CK & $\mathrm{CV}$ & $\mathrm{CO}$ & CR & $\mathrm{CH}$ & CB \\
\hline Petrologic type & 1 & $1-2$ & $3-6$ & $2-3$ & 3 & $1-2$ & 3 & 3 \\
\hline Chondrule abundance (vol.\%) & $\ll 1^{+}$ & $20 \ddagger$ & 15 & 45 & $40-48$ & $50-60$ & $\sim 70$ & $20-40$ \\
\hline Matrix abundance (vol.\%) & $>99^{+}$ & $70 \ddagger$ & 75 & 40 & $30-34$ & $30-50$ & 5 & $<5$ \\
\hline Refractory abundance * (vol.\%) & $\ll 1$ & 5 & 4 & 10 & 13 & 0.5 & 0.1 & $<0.1$ \\
\hline Metal (Fe,Ni) abundance (vol.\%) & $\ll 1$ & 0.1 & $\ll 1$ & $0-5$ & $1-5$ & $5-8$ & 20 & $60-80$ \\
\hline Average chondrule diameter (mm) & n.a. & 0.3 & $0.7-0.8$ & 1.0 & 0.15 & 0.7 & $0.02-0.09$ & $0.2-10$ \\
\hline $\begin{array}{l}\text { Olivine composition } \\
\left(\mathrm{mol}_{\%} \mathrm{Fe}_{2} \mathrm{SiO}_{4} ; \text { range }\right) \\
\left(\mathrm{mol}_{2} \mathrm{Fe}_{2} \mathrm{SiO}_{4} ; \text { mode }\right)\end{array}$ & * & * & $\begin{array}{l}<1-47 \\
29-33\end{array}$ & * & * & $1-3$ & $\begin{array}{c}<1-36 \\
2\end{array}$ & $\begin{array}{c}2-3 \\
3\end{array}$ \\
\hline Refractory lithophiles \# & 1.00 & 1.15 & 1.21 & 1.35 & 1.13 & 1.03 & 1.00 & $1.0-1.4$ \\
\hline
\end{tabular}

${ }^{+}$Including chondrule fragments and silicate minerals inferred to be chondrule fragments changes matrix and chondrule abundances to $>95 \mathrm{vol} . \%$ and $<5$ vol. \%, respectively. $\ddagger$ Variable. \# Calcium aluminum inclusions + amoeboid olivine aggregates. * Highly variable and unequilibrated. ${ }^{\sharp}$ Mean ratio refractory lithophiles relative to $\mathrm{Mg}$ and normalized to CI chondrites.

Thermal alteration characterized by increases in temperature can affect the mineralogical composition of chondrites through metamorphic reactions and localized recrystallization but not widespread melting (e.g., [315-319]). CK chondrites are a unique group of carbonaceous chondrites and are the only group that has experienced the full range of thermal alteration types [210,320]. Thermal modeling has been used to constrain the cooling histories of different chondrite parent bodies and is often achieved through the use of elemental gradients, trace elemental and isotopic composition, and radiometric ages calculated from the closure temperature of minerals during crystallization [321-325].

Aqueous alteration occurs when water ice in the parent body melts due to heat generated through radioactive decay of elements [326]. Water can alter the primary composition (both mineralogically and isotopically) of parent body materials through dissolution and formation of secondary hydrous phases, such as clays, serpentines, carbonates, sulfates, sulfides, halides, oxides, and oxyhydroxides [327]. Aqueous alteration can be determined through petrographic analysis of minerals, stable and radiogenic isotopes [328-332], as well as microtextures [333]. Although most chondrite groups have been affected by aqueous alteration to some degree, there are different types of aqueous alteration. Low temperature hydrothermal alteration occurs at temperatures below $200-300{ }^{\circ} \mathrm{C}$ [334] and can form mineral phases, such as phyllosilicates. At higher temperatures, typically above $300{ }^{\circ} \mathrm{C}$ [335], fluid-assisted metamorphism alters mineral composition. At similar temperatures, but in an open system where fluids are flowing through the rock and altering the composition, is referred to as metasomatism [336]. Some recent experimental studies have suggested that the initial parent body composition need not contain water, as heat from impact [337] or organic degradation [338] could induce aqueous alteration on parent bodies.

Alteration to physical and chemical properties by shock is a common and ongoing phenomenon in chondrites; this includes structural changes due to collision with meteorite parent bodies that can be related to pressure and temperature increases [339]. Shock propagation features can be difficult to deconvolve due to the heterogeneous nature of 
chondrites [340]. Changes to composition can include localized melting at the site of impact, as well as fracture features.

Formation of meteorite breccias (brecciation) involves the high-speed impact of meteorites that combine with other fragments of parent bodies [341]. Studying meteorite breccias is important for understanding early Solar System processes and combines a variety of the above-mentioned techniques, such as shock wave propagation, impact velocities, and textural analysis. Due to the variation in composition of the brecciated fragments, multiple parent body sources may be invoked.

Carbonaceous chondrites and the OM contained within them have been subject to thermal and aqueous processing. There are numerous studies that report on the effect of parent body alteration on amino acids, carboxylic acids, and nucleobase compositions [34,40,42,342-346]. The degree to which parent-body processing can affect organic molecule populations is largely dependent on the degree and type of alteration [347]. Petrological type 3 chondrites have undergone little to no thermal or aqueous processing (pristine). Types 1 and 2 have experienced aqueous alteration, while types 4,5 , and 6 have experienced thermal alteration, although not enough to start differentiation. The inventory (specific molecules and abundances) of organics can range markedly across meteorite class and degrees of alteration. For example, [45] reported amino acid distributions in $\mathrm{CB}$ and $\mathrm{CH}$ chondrites that differed markedly from those reported for type 2 and 3 CM and CR chondrites. The CB and CH chondrites contained beta-, gamma-, and delta-amino acid abundances that were much higher than the relative alpha amino acid abundances, evidencing multiple formation mechanisms. CI chondrites, which are type 1 (highest degree of aqueous alteration), have been reported to contain a higher abundance of beta-alanine relative to alpha-alanine and glycine, which is not the case of CM chondrites [42,348]. This suggests distinct parent bodies for CM and CI chondrites.

\section{Laboratory Analysis and Reactions}

\subsection{Analytical Instrumentation}

In laboratory settings, mineral and metal substrates have been demonstrated to be able to mediate different types of organic reactivity. This includes the synthesis of prebiotic materials, such as nucleobases and amino acids, as well as promoting metabolically relevant reactions [3-6,349-353]. In many of these cases, the enantioselectivity of the reaction was not explored. As we are growing to understand these factors, there are several avenues of research that can be explored to answer questions relevant to chirality at the origins of life. Herein, we summarize the alteration processes of minerals as well as relevant organic reactions that could impart asymmetry. We also make recommendations for future research endeavors in this field.

While the focus of this paper is organic reactions relevant to prebiotic chemistry and the origins of life, Table 1 highlights the diverse applications of enantioselective reactions for pharmaceutical, natural product, and other syntheses. Enantioselective synthesis plays a major role in pharmaceutical research, as drug design and testing investigate biological and pharmacological compounds that are chiral and whose chirality has significant implications on their active properties in biological systems [102,354,355]. As a result, there is much research centered around the analysis and detection of chiral compounds, the foremost being separation of enantiomers using chiral column chromatography [356,357]. Chirality can also be distinguished using spectroscopic and calorimetric techniques, and various other separation strategies (Table 6). While enantiomers have the same nuclear magnetic resonance (NMR) spectra, derivatization could allow for visible differences in the NMR by generating diastereomers or employing the use of chiral solvating agents without the need for diastereomer distinction [358]. Light scattering has been used previously for enantiomeric separation; however, this is extremely sensitive to other materials within the solution [359,360] and is currently not widely used [229]. 
Table 6. Analytical instrumentation used for separation and detection of racemic mixtures into chiral enantiomers grouped by primary analytical techniques. Included are their relevant fields of application and whether or not the technique used for chiral separation has been proposed or demonstrated in spaceflight.

\begin{tabular}{|c|c|c|c|c|c|}
\hline Instrument & Separation & Detector & Application & Mission Relevance & References \\
\hline \multicolumn{6}{|c|}{ Chromatography and Spectrometry } \\
\hline $\begin{array}{l}\text { Gas chromatography- } \\
\text { mass spectrometry }\end{array}$ & GC with a chiral column & MS & $\begin{array}{l}\text { Organic chemistry; } \\
\text { origins of life }\end{array}$ & $\begin{array}{l}\text { Cometary Sampling and Composition } \\
\text { (COSAC)-Rosetta: launched March } 2004 \\
\text { but sampling unsuccessful } \\
\text { Sample analysis at Mars-Mars Science } \\
\text { Laboratory: in progress, } \\
\text { landed August } 2012 \\
\text { Mars Organic Molecule Analyzer } \\
\text { (MOMA)-ExoMars: planned September } \\
2022 \text { launch }\end{array}$ & [361-365] \\
\hline $\begin{array}{l}\text { Liquid chromatography- } \\
\text { mass spectrometry; high } \\
\text { performance LC-MS }\end{array}$ & (HP)LC with a chiral column & MS (various) & $\begin{array}{l}\text { Organic chemistry; } \\
\text { origins of life }\end{array}$ & No & [366-368] \\
\hline $\begin{array}{l}\text { Sub- and supercritical fluid } \\
\text { chromatography (SFC) }\end{array}$ & $\mathrm{SF}\left(\mathrm{CO}_{2}\right.$ plus polar co-solvent) & $\begin{array}{l}\text { Various: UV-Vis, diode-array, } \\
\text { evaporative light scattering (ELS) } \\
\text { detector, charged-aerosol } \\
\text { detection, MS (atmospheric } \\
\text { pressure chemical ionization, } \\
\text { electrospray ionization) }\end{array}$ & $\begin{array}{l}\text { Organic chemistry; } \\
\text { forensics }\end{array}$ & No & {$[369,370]$} \\
\hline Capillary electrophoresis (CE) & $\mathrm{CE}$ & Laser-induced fluorescence (LIF) & $\begin{array}{c}\text { Origins of life; } \\
\text { organic chemistry; } \\
\text { instrument development }\end{array}$ & Proposed & [371-373] \\
\hline $\begin{array}{c}\text { Capillary } \\
\text { electrochromatography (CEC) }\end{array}$ & CE/HPLC & Various; UV detectors & Organic chemistry & No & [374-376] \\
\hline Ligand exchange $\mathrm{CE}$ & $\mathrm{CE}$ & Various; UV detectors & Organic chemistry & No & [377-379] \\
\hline Non-aqueous CE (NACE) & $\mathrm{CE}$ & $\begin{array}{l}\text { Various detectors; UV, } \\
\text { conductivity, MS, LIF }\end{array}$ & $\begin{array}{l}\text { Organic chemistry; } \\
\text { medicine }\end{array}$ & No & [380] \\
\hline $\begin{array}{l}\text { Ion-mobility mass spectrometry } \\
\text { (IM-MS) }\end{array}$ & $\begin{array}{l}\text { Derivatization, chiral } \\
\text { neutral gases }\end{array}$ & IM-MS & $\begin{array}{l}\text { Organic chemistry; } \\
\text { origins of life }\end{array}$ & $\begin{array}{l}\text { Volatile Organic Analyzer (VOA) on the } \\
\text { International Space Station (ISS); for air } \\
\text { quality control not enantiomeric } \\
\text { separation-deployed August } 2001\end{array}$ & [381-384] \\
\hline
\end{tabular}


Table 6. Cont.

\begin{tabular}{|c|c|c|c|c|c|}
\hline Instrument & Separation & Detector & Application & Mission Relevance & References \\
\hline Photodissociation & $\begin{array}{l}\text { Photodissociation in cold } \\
\text { gas phase }\end{array}$ & Various MS; e.g., ESI & Biochemistry & No & [385-387] \\
\hline $\begin{array}{l}\text { Matrix-assisted laser desorption } \\
\text { ionization (MALDI)—time of } \\
\text { flight (TOF) MS }\end{array}$ & $\begin{array}{c}\text { Stereosensitive } \\
\text { fragmentation (SF) }\end{array}$ & MALDI-TOF/TOF MS & Biochemistry & No & [388] \\
\hline \multicolumn{6}{|c|}{ Spectroscopy } \\
\hline $\begin{array}{l}\text { Nuclear Magnetic } \\
\text { Resonance (NMR) }\end{array}$ & $\begin{array}{l}\text { Various, derivatization } \\
\text { (typically to } \\
\text { form diastereomers) }\end{array}$ & NMR & Organic chemistry & No & {$[358,389]$} \\
\hline $\begin{array}{l}\text { Ultraviolet (UV)-visible (Vis) } \\
\text { spectrophotometry }\end{array}$ & Various & UV-Vis & Organic chemistry & No & {$[390,391]$} \\
\hline Infrared (IR) spectroscopy & Various, e.g., CE, NACE & FT-IR & Organic chemistry & No & {$[392,393]$} \\
\hline $\begin{array}{l}\text { Optical rotatory } \\
\text { dispersion (ORD) }\end{array}$ & Polarized light & Detector & Organic chemistry & No & {$[394,395]$} \\
\hline Circular dichroism (CD) & Circularly polarized light & CD detector (various) & $\begin{array}{l}\text { Organic chemistry; } \\
\text { biochemistry }\end{array}$ & No & [396-398] \\
\hline $\begin{array}{l}\text { Femto-second (fs) laser } \\
\text { mass spectrometry }\end{array}$ & fs-laser & MS & Organic chemistry & No & [399] \\
\hline Polarimetry & $\begin{array}{c}\text { Various; cavity ringdown, } \\
\text { near IR }\end{array}$ & Detector, photodetector & $\begin{array}{l}\text { Materials science; origins } \\
\text { of life }\end{array}$ & Proposed & [400-402] \\
\hline \multicolumn{6}{|c|}{ Optical techniques } \\
\hline Evaporative light scattering (ELS) & $\begin{array}{l}\text { Hydrophilic interaction } \\
\text { chromatography (HILIC) }\end{array}$ & Light scattering detector (LSD) & Organic chemistry & No & [403] \\
\hline ELS & $\begin{array}{l}\text { High performance liquid } \\
\text { chromatography (HPLC) }\end{array}$ & LSD & Organic chemistry & No & [404] \\
\hline Laser & Off-resonant laser beam & Detector & Nanotechnology & No & [405] \\
\hline Atomic force microscopy (AFM) & Optical tweezers & Optical and AFM & $\begin{array}{l}\text { Nanotechnology; } \\
\text { materials science }\end{array}$ & No & [406] \\
\hline
\end{tabular}


Table 6. Cont.

\begin{tabular}{|c|c|c|c|c|c|}
\hline Instrument & Separation & Detector & Application & Mission Relevance & References \\
\hline Polarization camera & Micropolarizer array & Detector & Origins of life & Proposed & [407] \\
\hline \multicolumn{6}{|c|}{ Calorimetry } \\
\hline $\begin{array}{l}\text { Differential scanning } \\
\text { calorimetry (DSC) }\end{array}$ & Thermal & Calorimeter & $\begin{array}{l}\text { Organic chemistry; } \\
\text { macromolecules }\end{array}$ & No & {$[254,408]$} \\
\hline \multicolumn{6}{|c|}{ Separation } \\
\hline Batch crystallization & Various; e.g., chromatography & $\begin{array}{l}\text { Model that calculates the optimal } \\
\text { conditions for separation }\end{array}$ & Organic chemistry & No & [409] \\
\hline $\begin{array}{c}\text { Diastereoisomeric } \\
\text { recrystallization }\end{array}$ & Crystallization & $\begin{array}{c}\text { Various, e.g., MS, DSC, X-ray } \\
\text { diffraction (XRD) }\end{array}$ & Organic chemistry & No & [410-412] \\
\hline Kinetic resolution & Various, e.g., chiral catalysts & Various, e.g., HPLC-MS, ESI-MS & Organic chemistry & No & [413-415] \\
\hline \multicolumn{6}{|c|}{ Labeling } \\
\hline Fluorescent sensors/dyes & $\begin{array}{l}\text { Various dyes, e.g., } \\
\text { 5-carboxyfluorescein } \\
\text { succinimidyl } \\
\text { ester, fluorescamine }\end{array}$ & $\begin{array}{l}\text { Various fluorescence detectors } \\
\text { (e.g., confocal } \\
\text { fluorescence microscope) }\end{array}$ & $\begin{array}{l}\text { Origins of life; } \\
\text { organic chemistry }\end{array}$ & Proposed & [416-420] \\
\hline
\end{tabular}




\subsection{Solution Phase Reactions}

For prebiotic chemistry, there are a variety of relevant asymmetric reactions (Table 1). Two important reactions for the synthesis of amino acids are reductive amination and the Strecker synthesis, [421]; see [422] and references therein. In addition, the formose reaction [423] is a common reaction cited in prebiotic chemistry for the abiotic synthesis of sugars. In the following sections, we describe these reactions and their relevance to studying the origins of life and prebiotic chemistry.

\subsubsection{Reductive Amination}

Reductive amination is a reaction of a carbonyl species (typically a ketone or aldehyde) with ammonia or an amine to generate an amine or an amino acid. The reaction occurs via synthesis of an imine precursor followed by reduction to access an amine as the final product. Figure 5 illustrates the reductive amination mechanism, indicating the chiral center generated. If the starting carbonyl material is an alpha keto-acid (e.g., pyruvic acid), the resulting product will be an amino acid, making this reaction relevant for the origins of life. Biologically, amino acid dehydrogenases catalyze such transformations, which are dependent on cofactors, such as nicotinamide adenine dinucleotide (NADH) and nicotinamide adenine dinucleotide phosphate (NADPH) [424].

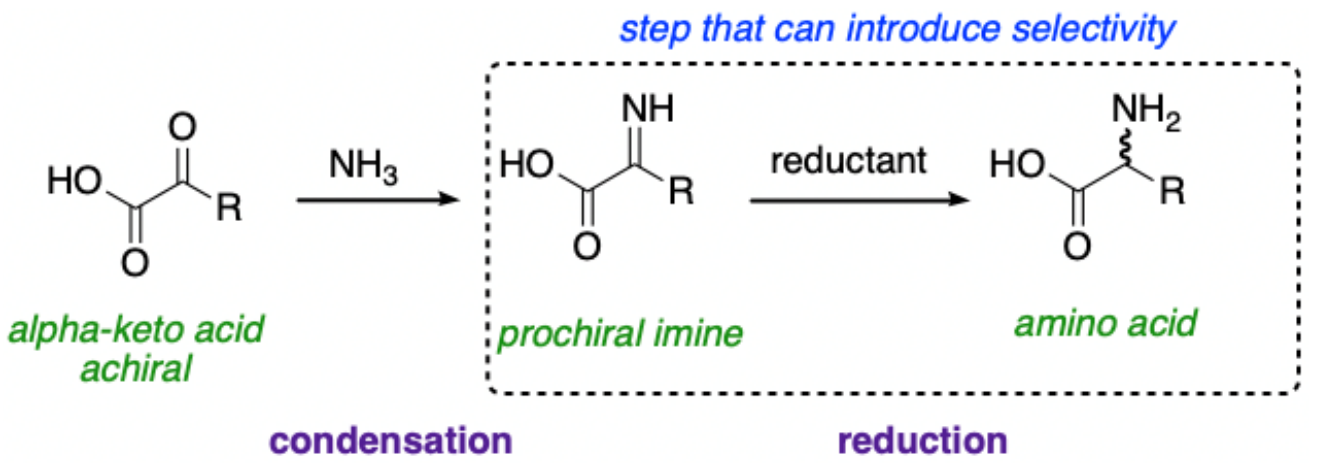

Figure 5. Reaction mechanism of an achiral alpha-keto acid reacting with ammonia to form a prochiral imine intermediate, which is then reduced to an amino acid. If the starting material is an aldehyde, an amine is the reaction product.

This reaction has been demonstrated to occur under geologic conditions [2-6,425]; however, these reactions do not give ee and there are limited reports of prebiotic asymmetric reductive amination reactions. Nucleotides have been reported as efficient catalysts for this reaction under prebiotic conditions [426]. In the field of organic chemistry, there are a variety of asymmetric reductive aminations, e.g., refs. [427-429].

\subsubsection{Strecker Synthesis}

Another mechanism for synthesizing amino acids is through Strecker synthesis [75,430-433] Strecker synthesis is a two-step process that, similar to reductive amination, begins with a carbonyl species, such as an aldehyde or a ketone. In the presence of ammonia and cyanide ions, it reacts to form an iminium ion intermediate followed by an attack of cyanide to form an $\alpha$-aminonitrile. This is the selectivity-inducing step. The aminonitrile is subsequently hydrolyzed under acidic conditions to form an amino acid (Figure 6). Strecker synthesis of amino acids form racemic products, but asymmetry can be imparted by substituting the ammonia in the reaction with chiral reagents [434-436].

In comparison to reductive amination, there are more asymmetric Strecker studies directly relevant to prebiotic chemistry. In addition, there are studies of the Strecker synthesis by using a single crystal face [437]. Depending on the face of the crystal used, Lor D-amino acids can be generated. Relevant to prebiotic chemistry, the Strecker synthesis can also be mediated by ribose [438] to access selective amino acid synthesis. 


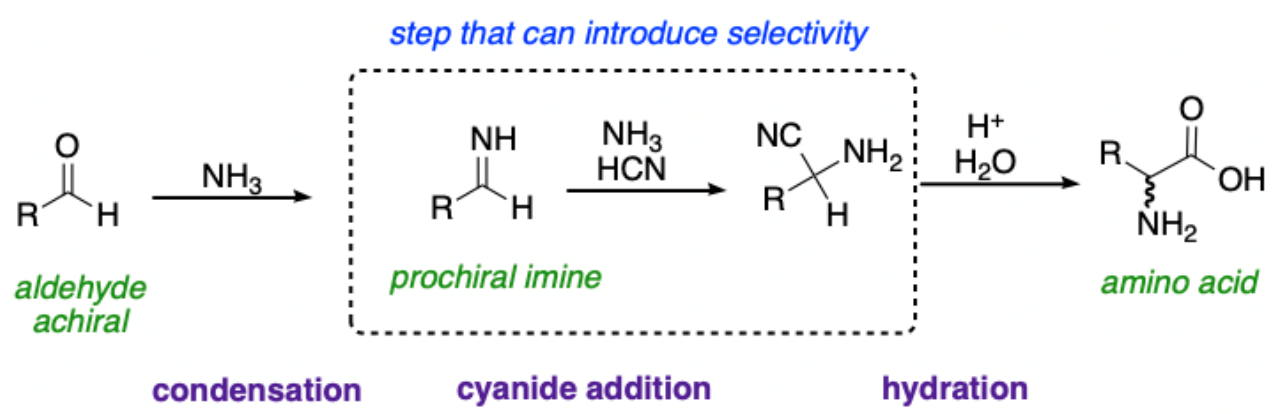

Figure 6. Reaction mechanism of an achiral aldehyde in presence of ammonia and cyanide to form an $\alpha$-aminonitrile intermediate and an amino acid following hydrolysis.

\subsubsection{Formose Reaction}

The formose reaction begins with formaldehyde, which, once it condenses to form glycolaldehyde, reacts autocatalytically to form sugars abiotically under alkaline conditions (Figure 7; [439]). Unlike the above examples, this reaction forms a variety of products related to sugars, including methanol, formic acid, sugar alcohols, branched sugars, sugar oligomers, sugar acids, and hydroxy acids, to name a few [174,440-442]. The formose reaction can be mediated by many different materials, including divalent cations, such as $\mathrm{Ca}^{2+}$ [443-446], and silicate minerals [447]. For a detailed review on conditions conducive for the formose reaction, see [422] and references therein.

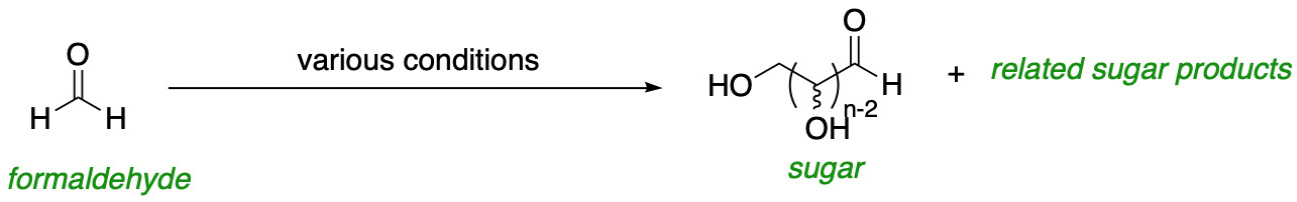

Figure 7. General outline of the formose reaction.

The formose reaction underpins the leading theory for the origin of sugars under prebiotic conditions (although the glyoxylate scenario is a proposed alternative [448]) and as such, further studies of asymmetric formose reactions are therefore particularly important, especially considering that the formose reaction is autocatalytic and could thus generate large ee if mediated by even scarce amounts of a chiral seed (see Section 6.5) Previous work has demonstrated how formose reactions can result in ee of the resulting D-sugars when conducted under conditions, such as UV-irradiation [449], or seeded with low concentrations of L-amino acids, namely proline [450,451].

\subsection{Solid-State Reactions}

While many reactions of interest to the prebiotic chemistry field are in the solution phase (homogenous or heterogenous), solid-state chemical reactions could also be relevant to this field. It has been demonstrated that amino acids, nucleotides, nucleosides, peptides, and sugars can be formed under mechanochemical conditions [452-455]. Metal-mediated and metal-catalyzed reactions have been demonstrated under mechanochemical conditions [456]. There are also examples of asymmetric reactions in the solid state $[457,458]$. Mechanochemical studies utilize mechanical energy to generate reactivity [459]; common examples include ball mill grinding and milling. The advantages associated with mechanochemical synthesis include increased productivity and efficiency [460], as well as resource conservation. These experiments do not require hazardous or expensive solvents and have overall lower energy requirements, vis-a-vis solution reactions [461-463].

While this is used in organic chemistry and materials science $[464,465]$, it is also applicable to planetary science and prebiotic chemistry as a way to mimic bombardment and other interactions. Early prebiotic organics could have been synthesized endogenously or delivered exogenously through impacts via asteroids or comets [466-469]. There is interest in simulating the effect of impacts on the petrologic [470,471] and organic [472-478] 
composition of prebiotically relevant materials, through the mechanochemical action of shock-wave propagation. In addition to simulating cometary impact events, there are impact simulations that investigate the effect of hypervelocity on the breakdown of organic compounds that are relevant for biosignature detection in spaceflight, particularly regarding spacecraft velocity during sampling [479,480].

\section{Recommendations for Future Research}

The origin of homochirality of life is a very broad topic; therefore, we recommend that multiple avenues should be explored. This includes experimental conditions/studies that are not directly applicable to prebiotic chemistry on Earth, which could be useful for understanding abiotic sources of organic homochirality and applied to the interpretation of potential biosignatures. We recommend, in the case of mineral-mediated organic reactivity, that the chirality of both the mineral substrate as well as the organic compound be taken into consideration. There has been a significant amount of research exploring mineralmediated prebiotic reactions and exploring such reactions with chiral mineral mediators would augment understanding.

\subsection{Capabilities of Flight-Ready Technology}

Significant ee is a potential biosignature $[48,481]$. As we look to find biosignatures on other planetary bodies, homochirality and organic preservation are two areas that deserve focus. The ability to determine chirality on other planetary bodies is an attractive endeavor, particularly in the astrobiology field. Additionally, organic preservation has been demonstrated to be enhanced by minerals and macromolecular matrices that provide protection against degradation; thus, organic-mineral interactions are also an area of importance when looking for potential biosignatures on other planets. There are a variety of instrument technologies that have been proposed and designed for space missions, which include a strong focus on colocated mineral and organic detection [482,483] and the separation of chiral organic molecules (e.g., [361,363,364]). The following sections describe the instruments, on three currently active missions (as of this writing), which are focused on the detection of chirality as a potential organic biosignatures.

\subsubsection{COSAC on Rosetta's Philae Lander}

The separation of chiral organics via the chiral column GC-MS has been proposed and flown on missions to comets [361,484,485] and Mars [363,364]. The European Space Agency (ESA)'s Rosetta mission launched a space probe in March 2004 to investigate the comet 67P/Churyumov-Gerasimenko. The mission consisted of the Rosetta spacecraft orbiter and the Philae lander. The ten-instrument suite on the Philae lander was designed to investigate the physical and chemical composition of a cometary nucleus through elemental, isotopic, mineralogical, molecular, surface, subsurface, and structural analysis. The plan was to accomplish these goals via drilling, imagery, spectrometry (gas chromatography and alpha particle $\mathrm{X}$-ray), gas analysis, radio transmission, surface and subsurface sensors, and magnetometry [486].

The chirality experiment involved two instrument subsystems; the sampling system (Sample Drilling and Distribution; SD2) and the GC-TOF-MS (Cometary Sampling and Composition; COSAC). SD2 consisted of a drill that was able to penetrate up to $230 \mathrm{~mm}$ into the subsurface to collect samples to deposit into a carousel with 26 ovens. The COSAC GC and TOF-MS had a total of eight GC columns on board, three of which were chiral GC columns (Table 7) with the capability to separate out and analyze amino acid enantiomers. Due to complications that occurred during Philae's detachment from the Rosetta spacecraft and landing on the surface of 67P/Churyumov-Gerasimenko in November 2004, the COSAC experiment was not attempted and samples could not be acquired [365]. Although the chirality experiment was not conducted due to landing issues, COSAC was able to sample the atmosphere in a passive mode, 25 min post-landing. The acquired mass 
spectrum indicated 16 organic species were present, including four compounds that had not previously been detected in comets [487].

Table 7. Chiral GC columns flown or proposed on missions for enantiomeric separation of organics. ESA-European Space Agency; NASA-National Aeronautics and Space Administration; MSL-Mars Science Laboratory; COSAC-Cometary Sampling and Composition; SAM-Sample Analysis at Mars; MOMA-Mars Organic Molecule Analyzer.

\begin{tabular}{cccccc}
\hline Agency & Mission & Status & Instrument & $\begin{array}{c}\text { Total GC } \\
\text { Columns }\end{array}$ & Chiral Column(s) \\
\hline ESA & Rosetta & $\begin{array}{c}\text { Flown but } \\
\text { unsuccessful }\end{array}$ & COSAC & 8 & $\begin{array}{c}\text { Chirasil Dex CB } \\
\text { Chirasil L Val } \\
\text { Cyclodextrin G-TA }\end{array}$ \\
$\begin{array}{c}\text { NASA } \\
\text { ESA } / \text { Roscosmos }\end{array}$ & $\begin{array}{c}\text { MSL } \\
\text { ExoMars }\end{array}$ & $\begin{array}{c}\text { In progress } \\
\text { Planned }\end{array}$ & $\begin{array}{c}\text { SAM } \\
\text { MOMA }\end{array}$ & 6 & $\begin{array}{c}\text { Chirasil- } \beta \text { Dex CB } \\
\text { CP Chirasil Dex }\end{array}$ \\
\hline
\end{tabular}

\subsubsection{SAM on MSL's Curiosity Rover}

The Martian surface and subsurface has long been considered a prime astrobiological life detection target [48,488-490]. Currently, information about the organic inventory and geological context of Mars is sourced from the study of Martian meteorites [491-493] as well as landed spacecraft that have or are currently exploring the Martian surface [494,495]. NASA's Mars Science Laboratory (MSL) Curiosity rover landed in Gale crater in August 2012. The instrument payload suite includes the Sample Analysis at Mars (SAM) instrument.

The SAM instrument's primary scientific goals include characterization of the composition of Martian atmosphere and the composition of organics within surface and subsurface sediments [363]. SAM consists of a tunable laser spectrometer (TLS), GC, and a quadrupole mass spectrometer (QMS). The GC has six chemically different $30 \mathrm{~m}$ columns for the separation of polar and non-polar organic compounds, one of which is a chiral column intended to separate volatile organic compound enantiomers (Table 7; 363). In a laboratory experiment designed to simulate the flight conditions of the chiral column on the SAM GC, Chirasil- $\beta$ Dex was used to separate out chlorohydrocarbon compounds at low $\left(35^{\circ} \mathrm{C}\right)$ and high $\left(185^{\circ} \mathrm{C}\right)$ temperatures. The temperatures were chosen to approximate the dynamic range of temperatures that would be experienced in flight $\left(30^{\circ} \mathrm{C}\right.$ and $200{ }^{\circ} \mathrm{C}$ are the minimum and maximum GC operating temperatures on SAM, respectively). The results of the experiment demonstrated that 1,2-dichloropropane enantiomers were partially separated at the low temperature; however, at the higher temperature experiment, the enantiomers coeluted [496].

\subsubsection{MOMA on ExoMars' Rosalind Franklin Rover}

ESA's and Roscosmos's Rosalind Franklin rover, part of the ExoMars mission, is scheduled for launch in September 2022 to land in Oxia Planum, Mars, in June 2023 [497]. The goal of the ExoMars mission is to look for signs of past or present life using an instrument suite that will characterize the geochemical environment contained in the surface and subsurface. With a drill capable of reaching $2 \mathrm{~m}$ into the subsurface, samples taken by Rosalind Franklin have a higher likelihood of containing sediments that are less affected by radiation and surface oxidation [498].

The Mars Organic Molecule Analyzer (MOMA) consists of a pyrolysis GC-MS and a laser desorption ionization MS (LDI-MS). These two techniques, which ionize samples thermolytically through pyrolysis and are induced by laser ionization, ensure that a wide range of small organic compounds, as well as larger refractory phases, will volatilize for spectral analysis. The GC portion of MOMA contains four chemically distinct GC columns, one of which is a chiral column (Table 7) capable of separating enantiomers. Portions of the MOMA payload contain hardware heritage that is similar to the COSAC experiment aboard Rosetta and SAM aboard Curiosity [364]. 
Along with the flight models of the instruments discussed above, there exist many brassboard instruments in laboratories that can be used to enhance our knowledge and extend the capabilities of flight technology but with the full range of resources accessible to ground laboratories on Earth (e.g., [499]). We recommend continued testing of analog instruments that are in flight as well as proposed flight-ready instruments at all technology readiness levels (TRLs), along with the traditional techniques used for chiral detection. The generation of extensive datasets from analog and brassboard instruments will help to calibrate and interpret results returned from missions, as well as optimize parameters to be used in new instrument technologies.

\subsection{Next Generation Instrumentation}

In addition to existing instruments, the development of new instruments or instrument capabilities to detect chirality in spaceflight is a necessary component in the search for signs of past life. Advancements in the fields of organic separation (e.g., [500-504]) and detection through mass spectrometry $[505,506]$ are needed to enhance the field of chiral separation on spaceflight missions. Refinement of traditional chiral separation and detection methods as well as the development of new analytical strategies to investigate chiral organics [407,420,507-509] and minerals [510] should be prioritized. Analytical advancements, coupled with progress in spaceflight technology, represent an exciting step forward in the study of prebiotic chemistry and the detection of chirality on Earth and other planetary bodies.

\subsection{Contamination Control}

Habitability and life detection missions commonly need to address issues related to contamination and outgassing in accordance with guidelines suggested by the International Committee on Space Research (COSPAR) for planetary protection (e.g., [48,511,512]). Missions and proposed mission concepts that address contamination control issues are typically or wholly concerned with adhering to the requirements set out by planetary protection (PP) guidelines, through verification and quantification of bioburden on instrument and spacecraft surfaces. Bioburden, a quantitative measure of the number of viable microorganisms on any given surface, is not only important to verify from the perspective of PP (so as not to contaminate a planetary body with Earth microorganisms and vice versa), but to ensure that the in situ measurements being made in low biomass environments are genuine, and not a false positive as a result of cross-contamination [513].

Organic contamination in in situ chemical analysis during spaceflight is always a prime concern, particularly given the low threshold of background organic material, which would amplify any detection of trace organic contaminants. Missions focused on life detection and biosignature preservation that target sensitive parameters, such as amino acid ee, need to prioritize contamination control not only during spacecraft assembly and testing but also instrument operations and data returned for analysis [514]. When determining chirality in organic compounds during life detection missions, contamination could arise from malfunctioning instrumentation [515], sampling [365], or terrestrial contamination [516]. Strategies employed for dealing with contamination include the use of sterilization procedures, e.g., decontamination heaters, UV radiation, chemical, and low-heat plasma ([517] and references therein) and limiting the use of solvents and/or derivatization agents [500].

\subsection{Future Directions}

There are many fields that are interested in and actively researching the chirality of organic and mineral systems, as evidenced by the extensive and growing number of enantioselective techniques (reactions and analytical applications) being developed (Tables 1 and 6). While research in chirality has been dominated by organic synthesis of natural products and bioactive compounds of interest to the pharmaceutical industry, its relevance and importance continues to grow in the field of life detection and origins of life. Research in combining state-of-the-art separation and detection techniques with analog and laboratory studies to constrain conditions in which asymmetric prebiotic reactions are 
favored. This would increase our understanding of what life requires, or what conditions should be present for life to be established and to thrive, regardless of whether it is life that is familiar to us or not. In order to address the use of chiral asymmetry as a biosignature, multidisciplinary collaboration is key to facilitating the development of new technology, which could lead to new field-defining instrumentation in the field $[124,422,518]$ and references therein.

\section{Conclusions}

Homochirality is of great interest and importance to prebiotic chemistry as well as those researching the origins of life. Chirality is an important property observed in both organic materials and mineral structures and these structural properties have implications for reactivity and analysis. Understanding both organic and mineral chiral systems is relevant for prebiotic chemistry, as the origins of life had to occur in a geologic context of some kind. We have described asymmetric organic reactions as well as mineral alterations that involve chiral systems to emphasize their relevance to geological processes and highlight the diversity in their applications. Lastly, we recommended some future research directions in the field of chiral organic and mineral systems, in particular, technological and scientific advancements that include: (1) Identifying additional chiral organics and chiral minerals that could be used as biosignatures; (2) focusing on geologically and astrobiologically relevant reactions and systems; and (3) designing instruments that can be modified for spaceflight and remote operation to further the search for life on other worlds.

Supplementary Materials: The following supporting information can be downloaded at: https: / / www.mdpi.com/article/10.3390/sym14030460/s1; Table S1: List of chiral minerals identified by their space group.

Author Contributions: C.L., J.M.W., L.E.R., R.Y.S., L.M.B., E.L.B. and A.S.B. contributed to the writing-review and editing of the manuscript. All authors have read and agreed to the published version of the manuscript.

Funding: J.M.W. and L.M.B. were supported by NASA/NSF Ideas Lab for the Origins of Life, "Becoming Biotic: Recapitulating Ancient Cofactor-Mediated Metabolic Pathways on the Early Earth". J.M.W., L.M.B., and L.E.R. were supported by JPL Strategic Research and Technology Development (R\&TD), "Fate of Organics on Ocean Worlds". R.Y.S. was supported by a JPL Strategic Research and Technology Development (R\&TD), "Experimental Constraints on Groundwater Driven Redox Gradients on Mars." A.S.B. was supported by the Planetary Science Division at NASA Headquarters.

Institutional Review Board Statement: Not applicable.

Informed Consent Statement: Not applicable.

Data Availability Statement: Not applicable.

Acknowledgments: The authors acknowledge three anonymous reviewers for providing constructive comments that improved the manuscript's final version. Work by J.M.W., L.E.R., R.Y.S., and L.M.B. was carried out at the Jet Propulsion Laboratory, California Institute of Technology, under a contract with the National Aeronautics and Space Administration (80NM0018D0004).

Conflicts of Interest: The authors declare no conflict of interest.

\section{References}

1. Cafferty, B.J.; Gállego, I.; Chen, M.C.; Farley, K.I.; Eritja, R.; Hud, N.V. Efficient self-assembly in water of long noncovalent polymers by nucleobase analogues. J. Am. Chem. Soc. 2013, 135, 2447-2450. [CrossRef]

2. Novikov, Y.; Copley, S.D. Reactivity landscape of pyruvate under simulated hydrothermal vent conditions. Proc. Natl. Acad. Sci. USA 2013, 110, 13283-13288. [CrossRef]

3. Muchowska, K.B.; Varma, S.J.; Chevallot-Beroux, E.; Lethuillier-Karl, L.; Li, G.; Moran, J. Metals promote sequences of the reverse Krebs cycle. Nat. Ecol. Evol. 2017, 1, 1716-1721. [CrossRef]

4. Muchowska, K.B.; Varma, S.J.; Moran, J. Synthesis and breakdown of universal metabolic precursors promoted by iron. Nature 2019, 569, 104-107. [CrossRef] 
5. $\quad$ Barge, L.M.; Flores, E.; Baum, M.M.; VanderVelde, D.G.; Russell, M.J. Redox and pH gradients drive amino acid synthesis in iron oxyhydroxide mineral systems. Proc. Natl. Acad. Sci. USA 2019, 116, 4828-4833. [CrossRef] [PubMed]

6. Barge, L.M.; Flores, E.; VanderVelde, D.G.; Weber, J.M.; Baum, M.M.; Castonguay, A. Effects of geochemical and environmental parameters on abiotic organic chemistry driven by iron hydroxide minerals. JGR Planets 2020, 125, e2020JE006423. [CrossRef]

7. Kitadai, N.; Nakamura, R.; Yamamoto, M.; Takai, K.; Yoshida, N.; Oono, Y. Metals likely promoted protometabolism in early ocean alkaline hydrothermal systems. Sci. Adv. 2019, 5, eaav7848. [CrossRef] [PubMed]

8. Fani, R. The origin and evolution of metabolic pathways: Why and how did primordial cells construct metabolic routes? Evol. Educ. Outreach 2012, 5, 367-381. [CrossRef]

9. Preiner, M.; Xavier, J.C.; do Nascimento Vieria, A.; Kleinermanns, K.; Allen, J.F.; Martin, W.F. Catalysts, autocatalysis and the origin of metabolism. Interface Focus 2019, 9, 20190027. [CrossRef]

10. Vogt, P.F.; Miller, M.J. Development and applications of amino acid-derived chiral acylnitroso hetero Diels-Alder reactions. Tetrahedron 1998, 54, 1317-1348. [CrossRef]

11. Zhou, J.; Tang, Y. The development and application of chiral trisoxazolines in asymmetric catalysis and molecular recognition. Chem. Soc. Rev. 2005, 34, 664-676. [CrossRef]

12. Smith, D.K. Lost in translation? Chirality effects in the self-assembly of nanostructured gel-phase materials. Chem. Soc. Rev. 2009, 38, 684-694. [CrossRef]

13. Li, Y.; Pan, B.; He, X.; Xia, W.; Zhang, Y.; Liang, H.; Subba Reddy, C.V.; Cao, R.; Qiu, L. Pd-catalyzed asymmetric Suzuki-Miyaura coupling reactions for the synthesis of chiral biaryl compounds with a large steric substituent at the 2-position. Beilstein J. Org. Chem. 2020, 16, 966-973. [CrossRef]

14. Burton, A.S.; Berger, E.L. Insights into abiotically-generated amino acid enantiomeric excesses found in meteorites. Life 2018, 8, 14 . [CrossRef]

15. Blackmond, D.G. The origin of biological homochirality. Cold Spring Harb. Perspect. Biol. 2019, 11, a032540. [CrossRef]

16. Sczepanski, J.T.; Joyce, G.F. A cross-chiral RNA polymerase ribozyme. Nature 2014, 515, 440-442. [CrossRef]

17. Glavin, D.P.; Burton, A.S.; Elsila, J.E.; Aponte, J.C.; Dworkin, J.P. The search for chiral asymmetry as a potential biosignature in our Solar System. Chem. Rev. 2020, 120, 4660-4689. [CrossRef]

18. Ehrenfreund, P.; Irvine, W.; Becker, L.; Blank, J.; Brucato, J.R.; Colangeli, L.; Derenne, S.; Despois, D.; Dutrey, A.; Fraaije, H. Astrophysical and astrochemical insights into the origin of life. Rep. Prog. Phys. 2002, 65, 1427. [CrossRef]

19. Kwok, S. The synthesis of organic and inorganic compounds in evolved stars. Nature 2004, 430, 985-991. [CrossRef]

20. Kwok, S. Organic matter in space: From star dust to the Solar System. Astrophys. Space Sci. 2008, 319, 5-21. [CrossRef]

21. Kwok, S. Complex organics in space from Solar System to distant galaxies. Astron. Astrophys. Rev. 2016, 24, 8. [CrossRef]

22. Ehrenfreund, P.; Cami, J. Cosmic carbon chemistry: From the interstellar medium to the early Earth. Cold Spring Harb. Perspect. Biol. 2010, 2, a002097. [CrossRef]

23. Ehrenfreund, P.; Charnley, S.B. Organic molecules in the interstellar medium, comets, and meteorites: A voyage from dark clouds to the Early Earth. Annu. Rev. Astron. Astrophys. 2000, 38, 427-483. [CrossRef]

24. Brandenburg, A. Homochirality: A prerequisite or consequence of life? In Prebiotic Chemistry and the Origin of Life. Advances in Astrobiology and Biogeophysics; Neubeck, A., McMahon, S., Eds.; Springer: Cham, Switzerland, 2021. [CrossRef]

25. Frank, F.C. 1953. On spontaneous asymmetric synthesis. Biochim. Biophys. Acta 1953, 11, 459-463. [CrossRef]

26. Soai, K.; Shibata, T.; Morioka, H.; Choji, K. Asymmetric autocatalysis and amplification of enantiomeric excess of a chiral molecule. Nature 1995, 378, 767-768. [CrossRef]

27. Soai, K.; Osanai, S.; Kadowaki, K.; Yonekubo, S.; Shibata, T.; Sato, I. d- and l-quartz-promoted highly enantioselective synthesis of a chiral organic compound. J. Am. Chem. Soc. 1999, 121, 11235-11236. [CrossRef]

28. Orme, C.A.; Noy, A.; Wierzbicki, A.; McBride, M.T.; Grantham, M.; Teng, H.H.; Dove, P.M.; DeYoreo, J.J. Formation of chiral morphologies through selective binding of amino acids to calcite surface steps. Nature 2001, 411, 775-779. [CrossRef]

29. Wagner, A.J.; Zubarev, D.Y.; Aspuru-Guzik, A.; Blackmond, D.G. Chiral sugars drive enantioenrichment in prebiotic amino acid synthesis. ACS Cent. Sci. 2017, 3, 322-328. [CrossRef]

30. Flores, J.J.; Bonner, W.A.; Massey, G.A. Asymmetric photolysis of (RS)-leucine with circularly polarized ultraviolet light. J. Am. Chem. Soc. 1977, 99, 3622-3625. [CrossRef]

31. Takano, Y.; Takahashi, J.; Kaneko, T.; Marumo, K.; Kobayashi, K. Asymmetric synthesis of amino acid precursors in interstellar complex organics by circularly polarized light. Earth Planet. Sci. Lett. 2007, 254, 106-114. [CrossRef]

32. Modica, P.; Meinert, C.; de Marcellus, P.; Nahon, L.; Meierhenrich, U.J.; Le Sargent d'Hendecourt, L. Enantiomeric excesses induced in amino acids by ultraviolet circularly polarized light irradiation of extraterrestrial ice analogs: A possible source of asymmetry for prebiotic chemistry. Astrophys. J. 2014, 788, 79. [CrossRef]

33. Pizzarello, S.; Wang, Y.; Chaban, G.M. A comparative study of the hydroxy acids from the Murchison, GRA 95229 and LAP 02342 meteorites. Geochim. Cosmochim. Acta 2010, 74, 6206-6217. [CrossRef]

34. Aponte, J.C.; Elsila, J.E.; Hein, J.E.; Dworkin, J.P.; Glavin, D.P.; McLain, H.L.; Parker, E.T.; Cao, T.; Berger, E.L.; Burton, A.S. Analysis of amino acids, hydroxy acids, and amines in CR chondrites. Meteorit Planet Sci. 2020, 55, 2422-2439. [CrossRef]

35. Cronin, J.R.; Pizzarello, S. Enantiomeric excesses in meteoritic amino acids. Science 1997, 275, 951-959. [CrossRef]

36. Engel, M.H.; Macko, S.A. Isotopic evidence for extraterrestrial non- racemic amino acids in the Murchison meteorite. Nature 1997, 389, 265-268. [CrossRef] 
37. Pizzarello, S.; Cronin, J.R. Alanine enantiomers in the Murchison meteorite. Nature 1998, 394, 236. [CrossRef]

38. Pizzarello, S.; Cronin, J.R. Non-racemic amino acids in the Murray and Murchison meteorites. Geochim. Cosmochim. Acta 2000, 64, 329-338. [CrossRef]

39. Pizzarello, S.; Zolensky, M.; Turk, K.A. Nonracemic isovaline in the Murchison meteorite: Chiral distribution and mineral association. Geochim. Cosmochim. Acta 2003, 67, 1589-1595. [CrossRef]

40. Glavin, D.P.; Dworkin, J.P. Enrichment of the amino acid l-isovaline by aqueous alteration on CI and CM meteorite parent bodies. Proc. Natl. Acad. Sci. USA 2009, 106, 5487-5492. [CrossRef]

41. Herd, C.D.K.; Blinova, A.; Simkus, D.N.; Huang, Y.; Tarozo, R.; O’D Alexander, C.M.; Gyngard, F.; Nittler, L.R.; Cody, G.D.; Fogel, M.L.; et al. Origin and evolution of prebiotic organic matter as inferred from the Tagish Lake meteorite. Science 2011, 332, 1304-1307. [CrossRef]

42. Glavin, D.P.; Callahan, M.P.; Dworkin, J.P.; Elsila, J.E. The effects of parent body processes on amino acids in carbonaceous chondrites. Meteorit. Planet. Sci. 2010, 45, 1948-1972. [CrossRef]

43. Glavin, D.P.; Elsila, J.E.; Burton, A.S.; Callahan, M.P.; Dworkin, J.P.; Hilts, R.W.; Herd, C.K. Unusual nonterrestrial L-proteinogenic amino acid excesses in the Tagish Lake meteorite. Meteorit. Planet. Sci. 2012, 47, 1347-1364. [CrossRef]

44. Pizzarello, S.; Schrader, D.L.; Monroe, A.A.; Lauretta, D.S. Large enantiomeric excesses in primitive meteorites and the diverse effects of water in cosmochemical evolution. Proc. Natl. Acad. Sci. USA 2012, 109, 11945-11954. [CrossRef]

45. Burton, A.S.; Elsila, J.E.; Hein, J.E.; Glavin, D.P.; Dworkin, J.P. Extraterrestrial amino acids identified in metal-rich CH and CB carbonaceous chondrites from Antarctica. Meteorit. Planet. Sci. 2013, 48, 390-402. [CrossRef]

46. Cooper, G.; Rios, A.C. Enantiomer excesses of rare and common sugar derivatives in carbonaceous meteorites. Proc. Natl. Acad. Sci. USA 2016, 113, E3322-E3331. [CrossRef]

47. Thiemann, W. Life and chirality beyond the earth. Orig. Life Evol. Biosph. 1975, 6, 475-481. [CrossRef] [PubMed]

48. Neveu, M.; Hays, L.E.; Voytek, M.A.; New, M.H.; Schulte, M.D. The ladder of life detection. Astrobiology 2018, 18, 1375-1402. [CrossRef] [PubMed]

49. Avnir, D. Critical review of chirality indicators of extraterrestrial life. New Astron. Rev. 2021, 92, 101596. [CrossRef]

50. Aliashkevich, A.; Alvarez, L.; Cava, F. New insights into the mechanisms and biological roles of D-amino acids in complex ecosystems. Front. Microbiol. 2018, 9, 683. [CrossRef] [PubMed]

51. Sasabe, J.; Suzuki, M. Emerging role of D-amino acid metabolism in the innate defense. Front. Microbiol. 2018, 9, 933. [CrossRef] [PubMed]

52. Hu, Y.; Zheng, Q.; Zhang, S.; Noll, L.; Wanek, W. Significant release and microbial utilization of amino sugars and D-amino acid enantiomers from microbial cell wall decomposition in soils. Soil Biol. Biochem. 2018, 23, 115-125. [CrossRef]

53. Pikuta, E.V.; Hoover, R.B.; Klyce, B.; Davies, P.C.W.; Davies, P. Bacterial utilization of L-sugars and D-amino acids. Proc. SPIE 2006, 6309, 63090A. [CrossRef]

54. Clayden, J.; Geeves, N.; Warren, S. Organic Chemistry, 2nd ed.; Oxford University Press: Oxford, UK, 2012.

55. Cross, L.C.; Klyne, W. Rules for the nomenclature of organic chemistry. Section E: Stereochemistry. Pure Appl. Chem. 1974, 45, 11-30. [CrossRef]

56. Gualtieri, G.; Geib, S.J.; Curran, D.P. A new class of chiral organogermanes derived from C2-symmetric dithiols: Synthesis, characterization and stereoselective free radical reactions. J. Org. Chem. 2003, 68, 5013-5019. [CrossRef]

57. Böhme, U.; Wiesner, S.; Günther, B. Easy access to chiral penta- and hexacoordinate silicon compounds. Inorg. Chem. Commun. 2006, 9, 806-809. [CrossRef]

58. Koga, S.; Ueki, S.; Shimada, M.; Ishii, R.; Kurihara, Y.; Yamanoi, Y.; Yuasa, J.; Kawai, T.; Uchida, T.; Iwamura, M.; et al. Access to chiral silicon centers for application to circularly polarized luminescence materials. J. Org. Chem 2017, 82, 6108-6117. [CrossRef]

59. Xu, L.-W. Chapter 4-Chiral organosilicon compounds. Organosilicon Compd. Theory Exp. 2017, 145-194. [CrossRef]

60. Montgomery, C.D. Factors affecting energy barriers for pyramidal inversion in amines and phosphines: A computational chemistry lab exercise. J. Chem. Educ. 2013, 90, 661-664. [CrossRef]

61. Mandal, N.; Pal, A.K.; Gain, P.; Zohaib, A.; Datta, A. Transition-state-like planar structures for amine inversion with ultralong $\mathrm{C}-\mathrm{C}$ bonds in diamino-o-carborane and diamino-o-dodecahedron. J. Am. Chem. Soc 2020, 142, 5331-5337. [CrossRef]

62. Kölmel, C.; Ochsenfeld, C.; Ahlrichs, R. An ab initio investigation of structure and inversion barrier of triisopropylamine and related amines and phosphines. Theor. Chim. Acta 1992, 82, 271-284. [CrossRef]

63. Marom, H.; Biedermann, U.; Agranat, I. Pyramidal inversion mechanism of simple chiral and achiral sulfoxides: A theoretical study. Chirality 2007, 19, 559-569. [CrossRef] [PubMed]

64. Xiao, Y.; Sun, Z.; Guo, H.; Kwon, O. Chiral phosphines in nucleophilic organocatalysis. Beilstein J. Org. Chem. 2014, 10, 2089-2121. [CrossRef] [PubMed]

65. Scott, K.A.; Njardarson, J.T. Analysis of US FDA-approved drugs containing sulfur atoms. Top. Curr. Chem. 2018, 376, 5. [CrossRef] [PubMed]

66. Bentley, R. Role of sulfur chirality in the chemical processes of biology. Chem. Soc. Rev. 2005, 34, 609-624. [CrossRef] [PubMed]

67. Wang, W.; Xiang, S.; Zhou, X.; Ji, Y.; Xiang, B. Enantiomeric separation and determination of the enantiomeric impurity of armodafinil by capillary electrophoresis with sulfobutyl ether- $\beta$-]cyclodextrin as chiral selector. Molecules 2012, 17, 303-314. [CrossRef] 
68. Lemouzy, S.; Giordano, L.; Hérault, D.; Buono, G. Introducing chirality at phosphorus atoms: An update on the recent synthetic strategies for the preparation of optically pure P-stereogenic molecules. Eur. J. Org. Chem. 2020, 2020, 3351-3366. [CrossRef]

69. Feng, H.-X.; Tan, R.; Liu, Y.-K. An efficient one-pot approach to the construction of chiral nitrogen-containing heterocycles under mild conditions. Org. Lett. 2015, 17, 3794-3797. [CrossRef]

70. Walsh, M.P.; Phelps, J.M.; Lennon, M.E.; Yufit, D.S.; Kitching, M.O. Enantioselective synthesis of ammonium cations. Nature 2021, 597, 70-76. [CrossRef]

71. Rickhaus, M.; Mayor, M.; Juríček, M. Strain-induced helical chirality in polyaromatic systems. Chem. Soc. Rev. 2016, 45, 1542-1556. [CrossRef]

72. Hassan, Z.; Spuling, E.; Knoll, D.M.; Lahann, J.; Bräse, S. Planar chiral [2.2]paracyclophanes: From synthetic curiosity to applications in asymmetric synthesis and materials. Chem. Soc. Rev. 2018, 47, 6947-6963. [CrossRef]

73. Noyori, R.; Takaya, H. BINAP: An efficient chiral element for asymmetric catalysis. Acc. Chem. Res. 1990, 23, 345-350. [CrossRef]

74. Welch, C.J.; Biba, M.; Sajonz, P. Fast methods of enantiopurity determination for the Soai reaction: Towards a general enantioenrichment detector? Chirality 2007, 19, 34-43. [CrossRef]

75. Wang, J.; Liu, X.; Feng, X. Asymmetric Strecker reactions. Chem. Rev. 2011, 111, 6947-6983. [CrossRef]

76. Ma, D.; Tian, H.; Zou, G. Asymmetric Strecker-type reaction of $\alpha$-aryl ketones. Synthesis of (S)- $\alpha$ M4CPG, (S)-MPPG, (S)-AIDA, and (S)-APICA, the antagonists of metabotropic glutamate receptors. J. Org. Chem. 1999, 64, 120-125. [CrossRef]

77. Wang, C.; Xiao, J. Asymmetric reductive amination. Top. Curr. Chem. 2014, 343, 261-282. [CrossRef]

78. Tian, Y.; Hu, L.; Wang, Y.-Z.; Zhang, X.; Yin, Q. Recent advances on transition-metal-catalysed asymmetric reductive amination. Org. Chem. Front. 2021, 8, 2328-2342. [CrossRef]

79. Ritson, D.; Sutherland, J. Prebiotic synthesis of simple sugars by photoredox systems chemistry. Nat. Chem. 2012, 4, 895-899. [CrossRef]

80. Stick, R.V.; Williams, S.J. The reactions of monosaccharides. In Carbohydrates: The Essential Molecules of Life, 2nd ed.; Elsevier Science: Amsterdam, The Netherlands, 2009; pp. 75-131. [CrossRef]

81. Katsuki, T.; Sharpless, K.B. The first practical method for asymmetric epoxidation. J. Am. Chem. Soc. 1980, $102,5974-5976$. [CrossRef]

82. Jacobsen, E.N.; Marko, I.; Mungall, W.S.; Schroeder, G.; Sharpless, K.B. Asymmetric dihydroxylation via ligand-accelerated catalysis. J. Am. Chem. Soc. 1988, 110, 1968-1970. [CrossRef]

83. Sharpless, K.B.; Patrick, D.W.; Truesdale, L.K.; Biller, S.A. New reaction. Stereospecific vicinal oxyamination of olefins by alkyl imido osmium compounds. J. Am. Chem. Soc. 1975, 97, 2305-2307. [CrossRef]

84. Midland, M.M.; Lee, P.E. Efficient asymmetric reduction of acyl cyanides with B-3-pinanyl 9-BBN (Alpine-borane). J. Org. Chem. 1985, 50, 3237-3239. [CrossRef]

85. Noyori, R.; Takaya, H.; Sayo, N.; Kumobayashi, H.; Akutagawa, S. Asymmetric hydrogenation of $\beta$-keto carboxylic esters. A practical, purely chemical access to $\beta$-hydroxy esters in high enantiomeric purity. J. Am. Chem. Soc. 1987, 109, 5856-5858. [CrossRef]

86. Hirao, A.; Itsuno, S.; Nakahama, S.; Yamazaki, N. Asymmetric reduction of aromatic ketones with chiral alkoxy-amineborane complexes. J. Chem.Soc. Chem. Commun. 1981, 7, 315-317. [CrossRef]

87. Corey, E.J.; Bakshi, R.K.; Shibata, S. Highly enantioselective borane reduction of ketones catalyzed by chiral oxazaborolidines. Mechanism and synthetic implications. J. Am. Chem. Soc. 1987, 109, 5551-5553. [CrossRef]

88. Corey, E.J. Catalytic enantioselective Diels-Alder reactions: Methods, mechanistic fundamentals, pathways, and applications. Angew. Chem. Int. Ed. 2002, 41, 1650-1667. [CrossRef]

89. Evans, D.A.; Chapman, K.T.; Bisaha, J. New asymmetric Diels-Alder cycloaddition reactions. Chiral.alpha.,.beta.-unsaturated carboximides as practical chiral acrylate and crotonate dienophile synthons. J. Am. Chem. Soc. 1984, 106, 4261-4263. [CrossRef]

90. Kozmin, S.A.; Rawal, V.H. Chiral amino siloxy dienes in the Diels-Alder reaction: Applications to the asymmetric synthesis of 4-substituted and 4,5-disubstituted cyclohexenones and the total synthesis of (-)- $\alpha$-elemene. J. Am. Chem. Soc. 1999, 121, 9562-9573. [CrossRef]

91. Hashimoto, S.; Komeshima, N.; Koga, K. Asymmetric Diels-Alder reaction catalysed by chiral alkoxyaluminium dichloride. J. Chem. Soc., Chem. Commun. 1979, 10, 437-438. [CrossRef]

92. Corey, E.J.; Imwinkelried, R.; Pikul, S.; Xiang, Y. Practical enantioselective Diels-Alder and aldol reactions using a new chiral controller system. J. Am. Chem. Soc. 1989, 111, 5493-5495. [CrossRef]

93. Kagan, H.B.; Riant, O. Catalytic asymmetric Diels Alder reactions. Chem. Rev. 1992, 92, 1007-1019. [CrossRef]

94. Cammidge, A.N.; Crépy, K.V.L. The first asymmetric Suzuki cross-coupling reaction. Chem. Commun. 2000, 18, 1723-1724. [CrossRef]

95. Schäfer, P.; Palacin, T.; Sidera, M.; Fletcher, S.P. Asymmetric Suzuki-Miyaura coupling of heterocycles via rhodium-catalysed allylic arylation of racemates. Nat. Commun. 2017, 8, 15762. [CrossRef]

96. Yuan, Y.; Yang, J.; Lei, A. Recent advances in electrochemical oxidative cross-coupling with hydrogen evolution involving radicals. Chem. Soc. Rev. 2021, 50, 10058-10086. [CrossRef]

97. Zheng, P.; Zhou, P.; Wang, D.; Xu, W.; Wang, H.; Xu, T. Dual Ni/photoredox-catalyzed asymmetric cross-coupling to access chiral benzylic boronic esters. Nat. Commun. 2021, 12, 1646. [CrossRef] 
98. Lautens, M.; Loup, J. Asymmetric reductive cross-coupling of aryl iodides with $\alpha$-chloroboranes by nickel/photoredox catalysis. Synfacts 2021, 17, 0657. [CrossRef]

99. Yuan, M.; Gutierrez, O. Mechanisms, challenges, and opportunities of dual Ni/photoredox-catalyzed C (sp2)-C (sp3) crosscouplings. Wiley Interdiscip. Rev. Comput. Mol. Sci. 2021, e1573. [CrossRef]

100. Cosgrove, S.C.; Thompson, M.P.; Ahmed, S.T.; Parmeggiani, F.; Turner, N.J. One-pot synthesis of chiral N-arylamines by combining biocatalytic aminations with Buchwald-Hartwig N-arylation. Angew. Chem. Int. Ed. 2020, 59, 18156-18160. [CrossRef]

101. Zhang, P.; Wang, X.-M.; Xu, Q.; Guo, C.-Q.; Wang, P.; Lu, C.-J. Enantioselective synthesis of atropisomeric biaryls by Pd-catalyzed asymmetric Buchwald-Hartwig amination. Angew. Chem. Int. Ed. 2021, 60, 21718-21722. [CrossRef]

102. Brooks, W.H.; Guida, W.C.; Daniel, K.G. The significance of chirality in drug design and development. Curr. Top. Med. Chem. 2011, 11, 760-770. [CrossRef]

103. Wang, Z. Advances in the asymmetric total synthesis of natural products ssing chiral secondary amine catalyzed reactions of $\alpha, \beta$-unsaturated aldehydes. Molecules 2019, 24, 3412. [CrossRef]

104. MacMillan, D.W.C. Facts-2021. NobelPrize.org. Nobel Prize Outreach AB. 2021. Available online: https://www.nobelprize.org/ prizes/chemistry/2021/macmillan/facts/ (accessed on 30 November 2021).

105. Ahrendt, K.A.; Borths, C.J.; MacMillan, D.W.C. New strategies for organic catalysis: The first highly enantioselective organocatalytic Diels-Alder reaction. J. Am. Chem. Soc. 2000, 122, 4243-4244. [CrossRef]

106. List, B.; Lerner, R.A.; Barbas, C.F. Proline-catalyzed direct asymmetric Aldol reactions. J. Am. Chem. Soc. 2000, 122, 2395-2396. [CrossRef]

107. Jacobsen, E.N.; MacMillan, D.W.C. Organocatalysis. Proc. Natl. Acad. Sci. USA 2010, 107, 20618-20619. [CrossRef]

108. Zhou, Q.-L. Privileged Chiral Ligands and Catalysts; Wiley-VCH Verlag GmbH \& Co., KGaA: Weinheim, Germany, 2011. [CrossRef]

109. Reetz, M.T.; Sell, T.; Meiswinkel, A.; Mehler, G. A new principle in combinatorial asymmetric transition-metal catalysis: Mixtures of chiral monodentate P ligands. Angew. Chem. Int. Ed. 2003, 42, 790-793. [CrossRef]

110. Yang, H.; Tang, W. Efficient enantioselective syntheses of chiral natural products facilitated by ligand design. Chem. Rec. 2020, 20, 23-40. [CrossRef]

111. Hamilton, G.L.; Kang, E.J.; Mba, M.; Toste, F.D. A powerful chiral counterion strategy for asymmetric transition metal catalysis. Science 2017, 317, 496-499. [CrossRef] [PubMed]

112. Herdeis, C.; Hubmann, H.P.; Lotter, H. Chiral pool synthesis of trans-(2S3S)-3-hydroxyproline and castanodiol from S-pyroglutamic acid. Tetrahedron Asymmetry 1994, 5, 119-128. [CrossRef]

113. Brill, Z.G.; Condakes, M.L.; Ting, C.P.; Maimone, T.J. Navigating the chiral pool in the total synthesis of complex terpene natural products. Chem. Rev. 2017, 117, 11753-11795. [CrossRef] [PubMed]

114. Cherney, A.H.; Kadunce, N.T.; Reisman, S.E. Enantioselective and enantiospecific transition-metal-catalyzed cross-coupling reactions of organometallic reagents to construct C-C bonds. Chem. Rev. 2015, 115, 9587-9652. [CrossRef]

115. Toste, F.D.; You, S.-L. Asymmetric synthesis enabled by organometallic complexes. Organometallics 2019, 38, 3899-3901. [CrossRef]

116. Parshall, G.W. Trends and opportunities for organometallic chemistry in industry. Organometallics 1987, 6, 687-692. [CrossRef]

117. Tang, J.; Redl, F.; Zhu, Y.; Siegrist, T.; Brus, L.E.; Steigerwald, M.L. An organometallic synthesis of TiO 2 nanoparticles. Nano Lett. 2005, 5, 543-548. [CrossRef]

118. Amiens, C.; Chaudret, B.; Ciuculescu-Pradines, D.; Collière, V.; Fajerwerg, K.; Fau, P.; Kahn, M.; Maisonnat, A.; Soulantica, K.; Phillipot, K. Organometallic approach for the synthesis of nanostructures. New J. Chem. 2013, 37, 3374-3401. [CrossRef]

119. Martins, P.; Marques, M.; Coito, L.; Pombeiro, A.J.L.; Baptista, P.V.; Fernandes, A.R. Organometallic compounds in cancer therapy: Past lessons and future directions. Anticancer Agents Med. Chem. 2014, 14, 1199-1212. [CrossRef]

120. Campeau, L.-C.; Fogg, D.E. The roles of organometallic chemistry in pharmaceutical research and development. Organometallics 2019, 38, 1-2. [CrossRef]

121. Kumar, A.; Sharma, R.; Kamaluddin, M.R. Formamide-based synthesis of nucleobases by metal(II) octacyanomolybdate(IV): Implication in prebiotic chemistry. Astrobiology 2014, 14, 769-779. [CrossRef]

122. Fioroni, M. Transition metal organometallic/metallorganic chemistry: Its role in prebiotic chemistry and life's origin. In Prebiotic Chemistry and the Origin of Life. Advances in Astrobiology and Biogeophysics; Neubeck, A., McMahon, S., Eds.; Springer: Cham, Switzerland, 2021; pp. 1-41. [CrossRef]

123. Frenkel-Pinter, M.; Sargon, A.B.; Glass, J.B.; Hud, N.V.; Williams, L.D. Transition metals enhance prebiotic depsipeptide oligomerization reactions involving histidine. RSC Adv. 2021, 11, 3534-3538. [CrossRef]

124. Barge, L.M.; Rodriguez, L.E.; Weber, J.M.; Theiling, B. Determining the "biosignature threshold" for life detection on biotic, abiotic, or prebiotic worlds. Astrobiology 2021. [CrossRef]

125. Kharasch, M.S.; Reynolds, W.B. Factors determining the course and mechanisms of Grignard reactions. X. The oxidation of Grignard reagents-Effect of metallic catalysts. J. Am. Chem. Soc. 1943, 65, 501-504. [CrossRef]

126. Bäckvall, J.E.; Sellen, M.; Grant, B. Regiocontrol in copper-catalyzed Grignard reactions with allylic substrates. J. Am. Chem. Soc. 1990, 112, 6615-6621. [CrossRef]

127. Herrmann, W.A.; Brossmer, C.; Reisinger, C.-P.; Riermeier, T.H.; Öfele, K.; Beller, M. Palladacycles: Efficient new catalysts for the Heck vinylation of aryl halides. Chem. A Eur. J. 1997, 3, 1357-1364. [CrossRef]

128. Martin, W.B.; Kateley, L.J. The Heck reaction: A microscale synthesis using a palladium catalyst. J. Chem. Educ. 2000, 77, 757. [CrossRef] 
129. Bhakta, S.; Ghosh, T. Emerging nickel catalysis in Heck reactions: Recent developments. Adv. Catal. Synth. 2020, 362, 5257-5274. [CrossRef]

130. Phan, N.T.S.; Van Der Sluys, M.; Jones, C.W. On the nature of the active species in palladium catalyzed Mizoroki-Heck and Suzuki-Miyaura couplings-homogeneous or heterogeneous catalysis, a critical review. Adv. Synth. Catal. 2006, 348, 609-679. [CrossRef]

131. Martin, R.; Buchwald, S.L. Palladium-catalyzed Suzuki-Miyaura cross-coupling reactions employing dialkylbiaryl phosphine ligands. Acc. Chem. Res. 2008, 41, 1461-1473. [CrossRef]

132. Percival, W.C.; Wagner, R.B.; Cook, N.C. Grignard reactions. XXI. The synthesis of aliphatic ketones. J. Am. Chem. Soc. 1953, 75, 3731-3734. [CrossRef]

133. Hazari, N.; Melvin, P.R.; Beromi, M.M. Well-defined nickel and palladium precatalysts for cross-coupling. Nat. Rev. Chem. 2017, 1, 0025. [CrossRef]

134. Weber, J.M.; Longstreet, A.R.; Jamison, T.F. Bench-stable nickel precatalysts with Heck-type activation. Organometallics 2018, 37, 2716-2722. [CrossRef]

135. Patel, B.H.; Percivalle, C.; Ritson, D.J.; Duffy, C.D.; Sutherland, J.D. Common origins of RNA, protein and lipid precursors in a cyanosulfidic protometabolism. Nat. Chem. 2015, 7, 301-307. [CrossRef]

136. Bartnikas, T.B.; Gitlin, J.D. How to make a metalloprotein. Nat. Struct. Mol. Biol. 2001, 8, 733-734. [CrossRef]

137. Messina, M.S.; Stauber, J.M.; Waddington, M.A.; Rheingold, A.L.; Maynard, H.D.; Spokoyny, A.M. Organometallic gold(III) reagents for cysteine arylation. J. Am. Chem. Soc. 2018, 140, 7065-7069. [CrossRef]

138. Kamo, N.; Kujirai, T.; Kurumizaka, H.; Murakami, H.; Hayashi, G.; Okamoto, A. Organoruthenium-catalyzed chemical protein synthesis to elucidate the functions of epigenetic modifications on heterochromatin factors. Chem Sci. 2021, 12, 5926-5937. [CrossRef]

139. Isied, S.; Lyon, J.; Vassilian, A. Peptide formation in the presence of metal ion protecting groups. II. Determination of the optical purity of amino acids and peptides bound to pentaamine cobalt (III). Int. J. Pept. Protein Res. 1982, 19, 354-360. [CrossRef]

140. Arbo, B.E.; Isied, S. Solid-phase synthesis of protected peptides using new cobalt(III) ammine linkers. Int. J. Pept. Protein Res. 1993, 42, 138-154. [CrossRef]

141. Ruf, A.; Kanawati, B.; Hertkorn, N.; Yin, Q.-Z.; Moritz, F.; Harir, M.; Lucio, M.; Michalke, B.; Wimpenny, J.; Shilobreeva, S.; et al. Previously unknown class of metalorganic compounds revealed in meteorites. Proc. Natl. Acad. Sci. USA 2017, 114, 2819-2824. [CrossRef]

142. Smith, K.E.; House, C.H.; Arevalo, R.D., Jr.; Dworking, J.P.; Callahan, M.P. Organometallic compounds as carriers of extraterrestrial cyanide in primitive meteorites. Nat. Commun. 2019, 10, 2777. [CrossRef]

143. Matzka, M.; Lucio, M.; Kanawati, B.; Quirico, E.; Bonal, L.; Loehle, S.; Schmitt-Kopplin, P. Thermal history of asteroid parent bodies is reflected in their metalorganic chemistry. ApJL 2021, 915, L7. [CrossRef]

144. Lunine, J.I. Origin of water ice in the Solar System. In Meteorites and the Early Solar System II; Lauretta, D.S., McSween, H.Y., Eds.; University of Arizona Press: Tucson, AZ, USA, 2006; pp. 309-319.

145. Slade, M.A.; Butler, B.J.; Muhleman, D.O. Mercury radar imaging: Evidence for polar ice. Science 1992, 258, 635-640. [CrossRef]

146. Ingersoll, A.P.; Svitek, T.; Murray, B.C. Stability of polar frosts in spherical bowl-shaped craters on the Moon, Mercury, and Mars. Icarus 1992, 100, 40-47. [CrossRef]

147. Paige, D.A.; Wood, S.E.; Vasavada, A.R. The thermal stability of water ice at the poles of Mercury. Science 1992, 258, 643-646. [CrossRef]

148. Namur, O.; Collinet, M.; Charlier, B.; Grove, T.L.; Holtz, F.; McCammon, C. Melting processes and mantle sources of lavas on Mercury. Earth Planet. Sci. Lett. 2016, 439, 117-128. [CrossRef]

149. Namur, O.; Charlier, B. Silicate mineralogy at the surface of Mercury. Nat. Geosci. 2017, 10, 9-13. [CrossRef]

150. Khodakovsky, I.L.; Volkov, V.P.; Sidorov, Y.I.; Borisov, M.V. Venus: Preliminary prediction of the mineral composition of surface rocks. Icarus 1979, 39, 352-363. [CrossRef]

151. Fegley, B.; Treiman, A.H.; Sharpton, V.L. Venus surface mineralogy: Observational and theoretical constraints. Proc. Lunar Planet. Sci. 1992, 22, 3-19.

152. Buffet, B.; Archer, D. Global inventory of methane clathrate: Sensitivity to changes in the deep ocean. Earth Planet Sci. Lett. 2004, 227, 185-199. [CrossRef]

153. Prockter, L.M. Ices in the Solar System. Johns Hopkins APL Tech. Dig. 2005, 26, 175-188.

154. Reimold, W.U.; Gibson, R.L. Processes on the early Earth. Geol. Soc. Am. 2006, 405. [CrossRef]

155. Westall, F.; Brack, A. The importance of water for life. Space Sci. Rev. 2018, 214, 50. [CrossRef]

156. Taylor, S.R.; Jakes, P. The geochemical evolution of the Moon. Proc. Lunar Sci. Conf. 1974, 5, 1287-1305.

157. Li, S.; Lucey, P.G.; Milliken, R.E.; Hayne, P.O.; Fisher, E.; Williams, J.-P.; Hurley, D.M.; Elphic, R.C. Direct evidence of surface exposed water ice in the lunar polar regions. Proc. Natl. Acad. Sci. USA 2018, 115, 8907-8912. [CrossRef]

158. Gendrin, A.; Mangold, N.; Bibring, J.-P.; Langevin, Y.; Gondet, B.; Poulet, F.; Bonello, G.; Quantin, C.; Mustard, J.; Arvidson, R.; et al. Sulfates in martian layered terrains: The OMEGA/Mars Express view. Science 2005, 307, 1587-1591. [CrossRef]

159. Bibring, J.-P.; Langevin, Y.; Mustard, J.F.; Poulet, F.; Arvidson, R.; Gendrin, A.; Gondet, B.; Mangold, N.; Pinet, P.; Forget, F.; et al. Global mineralogical and aqueous Mars history derived from OMEGA/Mars Express data. Science 2006, 312, 400-404. [CrossRef] 
160. Lasue, J.; Mangold, N.; Hauber, E.; Clifford, S.; Feldmann, W.; Gasnault, O.; Grima, C.; Maurice, S.; Mousis, O. Quantitative assessments of the Martian hydrosphere. Space Sci. Rev. 2013, 174, 155-212. [CrossRef]

161. Mousis, O.; Chassefière, E.; Holm, N.G.; Bouquet, A.; Hunter Waite, J.; Geppert, W.D.; Picaud, S.; Aikawa, Y.; Ali-Dib, M.; Charlou, J.-L.; et al. Methane clathrates in the Solar System. Astrobiology 2015, 15, 308-326. [CrossRef]

162. Owen, T.C.; Roush, T.L.; Cruikshank, D.P.; Elliot, J.L.; Young, L.A.; de Bergh, C.; Schmitt, B.; Geballe, T.R.; Brown, R.H.; Bartholomew, M.J. Surface ices and the atmospheric composition of Pluto. Science 1993, 261, 745-748. [CrossRef]

163. Mousis, O.; Gautier, D.; Coustenis, A. The D/H ratio in methane in Titan: Origin and history. Icarus 2002, 159, 156-165. [CrossRef]

164. Rivkin, A.S.; Howell, E.S.; Vilas, F.; Lebofsky, L.A. Hydrated minerals on asteroids: The astronomical record. In Asteroids III; Bottke, W.F., Jr., Cellino, A., Paolicchi, P., Binzel, P., Eds.; University of Arizona Press: Tucson, AZ, USA, 2002 ; pp. $235-253$.

165. Fujiwara, A.; Kawaguchi, J.; Yeomans, D.K.; Abe, M.; Okada, T.; Saito, J.; Yano, H.; Yoshikawa, M.; Scheeres, D.J.; Barnouin-Jha, O.; et al. The rubble-pile asteroid Itokawa as observed by Hayabusa. Science 2006, 312, 1330-1334. [CrossRef]

166. Waite, J.H., Jr.; Lewis, W.S.; Magee, B.A.; Lunine, J.I.; McKinnon, W.B.; Glein, C.R.; Mousis, O.; Young, D.T.; Brockwell, T.; Westlake, J.; et al. Liquid water on Enceladus from observations of ammonia and ${ }^{40} \mathrm{Ar}$ in the plume. Nature 2009, 460, 487-490. [CrossRef]

167. Schwartz, A.W. Did minerals perform prebiotic combinatorial chemistry? Chem. Biol. 1996, 3, 515-518. [CrossRef]

168. Walton, C.R.; Shorttle, O.; Jenner, F.E.; Williams, H.M.; Golden, J.; Morrison, S.M.; Downs, R.T.; Zerkle, A.; Hazen, R.M.; Pasek, M. Phosphorus mineral evolution and prebiotic chemistry: From minerals to microbes. Earth-Sci. Rev. 2021, 221, 103806. [CrossRef]

169. Bass, M.N. Montmorillonite and serpentine in Orgueil meteorite. Geochim. Cosmochim. Acta 1971, 35, 139-147. [CrossRef]

170. Tomeoka, K.; Buseck, P.R. Intergrown mica and montmorillonite in the Allende carbonaceous chondrite. Nature 1982, $299,326-327$. [CrossRef]

171. Pinnavaia, T.J. Intercalated clay catalysts. Science 1983, 220, 365-371. [CrossRef]

172. Herschy, B.; Whicher, A.; Camprubí, E.; Watson, C.; Dartnell, L.; Ward, J.; Evans, J.R.G.; Lane, N. An origin-of-life reactor to simulate alkaline hydrothermal vents. J. Mol. Evol. 2014, 79, 213-227. [CrossRef] [PubMed]

173. Sojo, V.; Herschy, B.; Whicher, A.; Camprubí, E.; Lane, N. The origin of life in alkaline hydrothermal vents. Astrobiology 2016, 16, 181-197. [CrossRef] [PubMed]

174. Kitadai, N.; Maruyama, S. Origins of building blocks of life: A review. Geosci. Front. 2018, 9, 1117-1153. [CrossRef]

175. Mompeán, C.; Marín-Yaseli, M.R.; Espigares, P.; González-Toril, E.; Zorzano, M.-P.; Ruiz-Bermejo, M. Prebiotic chemistry in neutral/reduced-alkaline gas-liquid interfaces. Sci. Rep. 2019, 9, 1916. [CrossRef] [PubMed]

176. Kadoya, S.; Krissansen-Totton, J.; Catling, D.C. Probable cold and alkaline surface environment of the Hadean Earth caused by impact ejecta weathering. Geochem. Geophys. Geosyst. 2020, 21, e2019GC008734. [CrossRef]

177. Hazen, R.M.; Sverjensky, D.A. Mineral surfaces, geochemical complexities, and the origins of life. Cold Spring Harb. Perspect. Biol. 2010, 2, A002162. [CrossRef]

178. Bernal, J.D. The physical basis of life. Proc. Phys. Soc. Sect. B 1951, 62, 597. [CrossRef]

179. Paecht-Horowitz, M.; Eirich, F.R. The polymerization of amino-acid adenylates on sodium montmorillonite with preadsorbed polypeptides. Orig. Life Evol. Biosph. 1988, 18, 359-387. [CrossRef]

180. Ferris, J.P.; Ertem, G. Oligomerization of ribonucleosides on montmorillonite: Reaction of the $5^{\prime}$-phosphoimidazolide of adenosine. Science 1992, 257, 1387-1389. [CrossRef]

181. Pitsch, S.; Eschenmoser, A.; Gedulin, B.; Hui, S.; Arrhenius, G. Mineral-induced formation of sugar phosphates. Orig. Life Evol. Biosph. 1995, 25, 297-334. [CrossRef]

182. Jiang, W.; Pacella, M.S.; Athanasiadou, D.; Nelea, V.; Vali, H.; Hazen, R.M.; Gray, J.J.; McKee, M.D. Chiral acidic amino acids induce chiral hierarchical structure in calcium carbonate. Nat. Commun. 2017, 8, 15066. [CrossRef]

183. Addadi, L.; Weiner, S. Crystals, asymmetry and life. Nature 2001, 411, 753-755. [CrossRef]

184. Grande, C.; Patel, N.H. Nodal signalling is involved in left-right asymmetry in snails. Nature 2009, 457, 1007-1011. [CrossRef]

185. Hazen, R.M. Chiral crystal faces of common rock-forming minerals. In Progress in Biological Chirality; Palyi, G., Zucchi, C., Caglioti, L., Eds.; Elsevier: Oxford, UK, 2004; pp. 137-151.

186. Hazen, R.M.; Filley, T.R.; Goodfriend, G.A. Selective adsorption of L- and D-amino acids on calcite: Implications for biochemical homochirality. Proc. Natl. Acad. Sci. USA 2001, 98, 5487-5490. [CrossRef]

187. Hazen, R.M.; Sholl, D.S. Chiral selection on inorganic crystalline surfaces. Nat. Mater. 2003, 2, 367-374. [CrossRef]

188. Hazen, R.M. Mineral surfaces and the prebiotic selection and organization of biomolecules. Am. Mineral. 2006, 91, 1715-1729. [CrossRef]

189. Cody, A.M.; Cody, R.D. Chiral habit modifications of gypsum from epitaxial-like adsorption of stereospecific growth inhibitors. J. Cryst. Growth 1991, 113, 508-519. [CrossRef]

190. Bortnovsky, O.; Sobafik, Z.; Wichterlová, B.; Bastl, Z. Structure of Al-Lewis site in beta zeolite active in the Meerwein-PonndorfVerley reduction of ketone to alcohol. J. Catal. 2002, 210, 171-182. [CrossRef]

191. Ponnamperuma, C.; Shimoyama, A.; Friebele, E. Clay and the origin of life. Orig. Life 1982, 12, 9-40. [CrossRef]

192. Siffert, B.; Naidja, A. Stereoselectivity of montmorillonite in the adsorption and deamination of some amino acids. Clay Miner. 1992, 27, 109-118. [CrossRef]

193. Ikeda, T.; Amoh, H.; Yasunaga, T. Stereoselective exchange kinetics of L- and D-histidines for chloride in the interlayer of a hydrotalcite-like compound by the chemical relaxation method. J. Am. Chem. Soc. 1984, 106, 5772-5775. [CrossRef] 
194. Fraser, D.G.; Fitz, D.; Jakschitz, T.; Rode, B.M. Selective adsorption and chiral amplification of amino acids in vermiculite clay-implications for the origin of biochirality. Phys. Chem. Chem. Phys. 2011, 13, 831-838. [CrossRef]

195. Fraser, D.G.; Greenwell, H.C.; Skipper, N.T.; Smalley, M.V.; Wilkinson, M.A.; Deme, B.; Heenan, R.K. Chiral interactions of histidine in a hydrated vermiculite clay. Phys. Chem. Chem. Phys. 2011, 13, 825-830. [CrossRef] [PubMed]

196. Downs, R.T.; Hazen, R.M. Chiral indices of crystalline surfaces as a measure of enantioselective potential. J. Mol. Catal. A Chem. 2004, 216, 273-285. [CrossRef]

197. Garcia, A.D.; Meinert, C.; Finger, F.; Meierheinrich, U.J.; Hejl, E. Racemate resolution of alanine and leucine on homochiral quartz, and its alteration by strong radiation damage. Life 2021, 11, 1222. [CrossRef]

198. Thompson, R.M.; Downs, R.T. Quantifying distortion from ideal closest-packing in a crystal structure with analysis and application. Acta Crystallogr. Sect. B 2001, 57, 119-127. [CrossRef] [PubMed]

199. Amariglio, A.; Amariglio, H.; Duval, X. Asymmetric reactions on optically active quartz. Helv. Chim. Acta 1968, 51, $2110-2115$. [CrossRef]

200. Bonner, W.A.; Kavasmaneck, P.R.; Martin, F.S.; Flores, J.J. Asymmetric adsorption of alanine by quartz. Science 1974, 186, 143-144. [CrossRef]

201. Bonner, W.A.; Kavasmaneck, P.R.; Martin, F.S.; Flores, J.J. Asymmetric adsorption by quartz: A model for the prebiotic origin of optical activity. Orig. Life 1975, 6, 367-376. [CrossRef]

202. Kahr, B.; Chittenden, B.; Rohl, A. Robert Boyle's chiral crystal chemistry: Computational re-evaluation of enantioselective adsorption on quartz. Chirality 2006, 18, 127-133. [CrossRef]

203. Easson, L.H.; Stedman, E. Molecular dissymmetry and physiological activity. J. Chem. Soc. 1933, 261, 1094-1098. [CrossRef]

204. Ogston, A.G. Interpretation of experiments on metabolic processes, using isotopic tracer elements. Nature 1984, $162,963$. [CrossRef]

205. Davankov, V.A. The nature of chiral recognition: Is it a three-point interaction? Chirality 1997, 9, 99-102. [CrossRef]

206. Asthagiri, A.; Hazen, R.M. An ab initio study of adsorption of alanine on the chiral calcite (213) surface. Mol. Simul. 2007, 33, 343-351. [CrossRef]

207. Booth, T.D.; Wahnon, D.; Wainer, I.W. Is chiral recognition a three-point process? Chirality 1997, 9, 96-98. [CrossRef]

208. Mesecar, A.D.; Koshland, D.E., Jr. A new model for protein stereospecificity. Nature 2000, 403, 614-615. [CrossRef]

209. Berthod, A. Chiral recognition mechanisms. Anal. Chem. 2006, 78, 2093-2099. [CrossRef]

210. Goldberg, S.I. Enantiomeric enrichment on the prebiotic earth. Orig. Life Evol. Biosph. 2007, 37, 55-60. [CrossRef] [PubMed]

211. Bada, J.L. Racemization of amino acids. In Chemistry and Biochemistry of the Amino Acids; Barrett, G.C., Ed.; Springer: Dordrecht, The Netherlands, 1985; pp. 399-414. [CrossRef]

212. Soai, K.; Matsumoto, A.; Kawasaki, T. Asymmetric autocatalysis as a link between crystal chirality and highly enantioenriched organic compounds. Isr. J. Chem. 2021, 61, 507-516. [CrossRef]

213. Sato, I.; Kadowaki, K.; Soai, K. Asymmetric synthesis of an organic compound with high enantiomeric excess induced by inorganic ionic sodium chlorate. Angew. Chem. Int. Ed. Engl. 2000, 39, 1510-1512. [CrossRef]

214. Sato, I.; Kadowaki, K.; Ohgo, Y.; Soai, K. Highly enantioselective asymmetric autocatalysis induced by chiral ionic crystals of sodium chlorate and sodium bromate. J. Mol. Catal. A Chem. 2004, 216, 209-214. [CrossRef]

215. Shindo, H.; Shirota, Y.; Niki, K.; Kawasaki, T.; Suzuki, K.; Araki, Y.; Matsumoto, A.; Soai, K. Asymmetric autocatalysis induced by cinnabar: Observation of the enantioselective adsorption of a 5-pyrimidyl alkanol on the crystal surface. Angew. Chem. Int. Ed. 2013, 52, 9135-9138. [CrossRef]

216. Matsumoto, A.; Ozawa, H.; Inumaru, A.; Soai, K. Asymmetric induction by retgersite, nickel sulfate hexahydrate, in conjunction with asymmetric autocatalysis. New J. Chem. 2015, 39, 6742-6745. [CrossRef]

217. Matsumoto, A.; Kaimori, Y.; Uchida, M.; Omori, H.; Kawasaki, T.; Soai, K. Achiral inorganic gypsum acts as an origin of chirality through Its enantiotopic surface in conjunction with asymmetric autocatalysis. Angew. Chem. Int. Ed. 2017, 56, 545-548. [CrossRef]

218. Kondepudi, D.K.; Kaufman, R.J.; Singh, N. Chiral symmetry breaking in sodium chlorate crystallization. Science 1990, 16, 975-976. [CrossRef]

219. McBride, J.M.; Carter, R.L. Spontaneous resolution by stirred crystallization. Angew. Chem. Intl. Ed. 1991, 30, 293-295. [CrossRef]

220. Shinitzky, M.; Nudelman, F.; Barda, Y.; Haimovitz, R.; Chen, E.; Deamer, D.W. Unexpected differences between D- and L-tyrosine lead to chiral enhancement in racemic mixtures. Orig. Life Evol. Biosph. 2002, 32, 285-297. [CrossRef]

221. Lahav, M.; Weissbuch, I.; Shavit, E.; Reiner, C.; Nicholson, G.J.; Schurig, V. Parity violating energetic difference and enantiomorphous crystals-Caveats; reinvestigation of tyrosine crystallization. Orig. Life Evol. Biosph. 2006, 36, 151-170. [CrossRef]

222. Goldberg, S.I. Experimental evidence leading to an alternative explanation of why D-tyrosine sometimes crystallizes faster than its L-enantiomer. Orig Life Evol. Biosph. 2008, 38, 149-153. [CrossRef]

223. Shinitzky, M.; Deamer, D. Comments in a discussion: Differential rates of D- and L-tyrosine crystallization. Orig. Life Evol. Biosph. 2008, 38, 271-275. [CrossRef]

224. Wu, C.; Wang, X.; Zhao, K.; Cao, M.; Xu, H.; Xia, D.; Lu, J.R. Molecular modulation of calcite dissolution by organic acids. Cryst. Growth Des. 2011, 11, 3153-3162. [CrossRef]

225. Frondel, C. Characters of quartz fibers. Am. Miner. 1978, 63, 17-27.

226. Evgenii, K.; Wolfram, T. The role of quartz in the origin of optical activity on Earth. Orig. Life Evol. Biosph. 2000, 30, 431-434. [CrossRef] 
227. Ulbricht, T.L.V. Asymmetry: The non-conservation of parity and optical activity. Q. Rev. Chem. Soc. 1959, 13, 48-60. [CrossRef]

228. Ulbricht, T.; Vester, F. Attempts to induce optical activity with polarized $\beta$-radiation. Tetrahedron. 1962, 18, 629-637. [CrossRef]

229. Myrgorodska, I.; Meinert, C.; Hoffmann, S.; Jones, N.; Nahon, L.; Meierhenrich, U. Light on chirality: Absolute asymmetric formation of chiral molecules relevant in prebiotic evolution. ChemPlusChem 2017, 82, 74-87. [CrossRef]

230. Nair, N.N.; Schreiner, E.; Marx, D. Glycine at the pyrite-water interface: The role of surface defects. J. Am. Chem. Soc. 2006, 128, 13815-13826. [CrossRef]

231. Xue, N.; Chen, X.; Nie, L.; Guo, X.; Ding, W.; Chen, Y.; Gu, M.; Xie, Z. Understanding the enhancement of catalytic performance for olefin cracking: Hydrothermally stable acids in P/HZSM-5. J. Catal. 2007, 248, 20-28. [CrossRef]

232. Fleming, G.J.; Adib, K.; Rodriguez, J.A.; Barteau, M.; White, J.; Idriss, H. The adsorption and reactions of the amino acid proline on rutile TiO2(1 10$)$ surfaces. Surf. Sci. 2008, 602, 2029-2038. [CrossRef]

233. $\mathrm{Wu}, \mathrm{J} . ;$

234. Yang, G.; Zhou, L. Zwitterionic versus canonical amino acids over the various defects in zeolites: A two-layer ONIOM calculation. Sci. Rep. 2014, 4, 6594. [CrossRef] [PubMed]

235. Li, X.; Li, H.; Yang, G. Promoting the adsorption of metal ions on kaolinite by defect sites: A molecular dynamics study. Sci. Rep. 2015, 5, 14377. [CrossRef]

236. Zaia, D.A.M.; Zaia, C.T.B.V. A few experimental suggestions using minerals to obtain peptides with a high concentration of L-amino acids and protein amino acids. Symmetry 2020, 12, 2046. [CrossRef]

237. Tosca, N.J.; McLennan, S.M. Chemical divides and evaporite assemblages on Mars. Earth Planet. Sci. Lett. 2006, $241,21-31$. [CrossRef]

238. Vaniman, D.T.; Martinez, G.M.; Rampe, E.B.; Bristow, T.F.; Blake, D.F.; Yen, A.S.; Ming, D.W.; Rapin, W.; Meslin, P.-Y.; Morookian, J.M.; et al. Gypsum, bassanite, and anhydrite at Gale crater, Mars. Am. Miner. 2018, 103, 1011-1020. [CrossRef]

239. Samotoin, N.D. Enantiomorphism of kaolinite: Manifestation at the levels of elementary layer and microcrystals. Crystallogr. Rep. 2011, 56, 327-334. [CrossRef]

240. Wray, J.J.; Milliken, R.E.; Dundas, C.M.; Swayze, G.A.; Andrews-Hanna, J.C.; Baldridge, A.M.; Chojnacki, M.; Bishop, J.L.; Ehlmann, B.L.; Murchie, S.L.; et al. Columbus crater and other possible groundwater-fed paleolakes of Terra Sirenum, Mars. JGR Planets 2011, 116, E01001. [CrossRef]

241. Cuadros, J.; Michalski, J.R. Investigation of Al-rich clays on Mars: Evidence for kaolinite-smectite mixed-layer versus mixture of end-member phases. Icarus 2013, 222, 296-306. [CrossRef]

242. Cairns-Smith, A.G.; Hall, A.J.; Russell, M.J. Mineral theories of the origin of life and an iron sulfide example. In Marine Hydrothermal Systems and the Origin of Life; Holm, N.G., Ed.; Springer: Dordrecht, The Netherlands, 1992; pp. 161-180. [CrossRef]

243. Zamaraev, K.I.; Romannikov, V.N.; Salganik, R.I.; Wlassoff, W.A.; Khramtsov, V.V. Modelling of the prebiotic synthesis of oligopeptides: Silicate catalysts help to overcome the critical stage. Orig. Life Evol. Biosph. 1997, 27, 325-337. [CrossRef]

244. Ruff, S.W. Spectral evidence for zeolite in the dust on Mars. Icarus 2004, 168, 131-143. [CrossRef]

245. Carter, J.; Poulet, F.; Bibring, J.P.; Mangold, N.; Murchie, S. Hydrous minerals on Mars as seen by the CRISM and OMEGA imaging spectrometers: Updated global view. J. Geophys. Res. Planets 2013, 118, 831-858. [CrossRef]

246. Christensen, P.R.; Wyatt, M.B.; Glotch, T.D.; Rogers, A.D.; Anwar, S.; Arvidson, R.E.; Banfield, J.L.; Blaney, D.L.; Budney, C.; Calvin, W.M.; et al. Mineralogy at Meridiani Planum from the mini-TES experiment on the Opportunity rover. Science 2004, 306, 1733-1739. [CrossRef]

247. Stromberg, J.M.; Applin, D.M.; Cloutis, E.A.; Rice, M.; Berard, G.; Mann, P. The persistence of a chlorophyll spectral biosignature from Martian evaporite and spring analogues under Mars-like conditions. Int. J. Astrobiol. 2013, 13, 203-223. [CrossRef]

248. Cockell, C.S.; Wilhelm, M.B.; Perl, S.; Wadsworth, J.; Payler, S.; McMahon, S.; Paling, S.; Edwards, T. 0.25 Ga salt deposits preserve signatures of habitable conditions and ancient lipids. Astrobiology 2020, 20, 864-877. [CrossRef]

249. De Sanctis, M.C.; Raponi, A.; Ammannito, E.; Ciarniello, M.; Toplis, M.J.; McSween, H.Y.; Castillo-Rogez, J.C.; Ehlmann, B.L.; Carrozzo, F.G.; Marchi, S.; et al. Bright carbonate deposits as evidence of aqueous alteration on (1) Ceres. Nature 2016, $536,54-57$. [CrossRef]

250. Raponi, A.; De Sanctis, M.C.; Carrozzo, F.G.; Ciarniello, M.; Castillo-Rogez, J.C.; Ammannito, E.; Frigeri, A.; Longobardo, A.; Palomba, E.; Tosi, F.; et al. Mineralogy of Occator crater on Ceres and insight into its evolution from the properties of carbonates, phyllosilicates, and chlorides. Icarus 2019, 320, 83-96. [CrossRef]

251. Banin, A.; Ben-Shlomo, T.; Margulies, L.; Blake, D.F.; Mancinelli, R.L.; Gehring, A.U. The nanophase iron mineral(s) in Mars soil. J. Geophys. Res. 1993, 98, 20831-20853. [CrossRef]

252. Madsen, M.B.; Hviid, S.F.; Gunnlaugsson, H.P.; Knudsen, J.M.; Goetz, W.; Pedersen, C.T.; Dinesen, A.R.; Mogensen, C.T.; Olsen, M.; Hargraves, R.B. The magnetic properties experiments on Mars Pathfinder. J. Geophys. Res. 1999, 104, 8761-8779. [CrossRef]

253. Morris, R.V.; Golden, D.C.; Bell, J.F., III; Shelfer, T.D.; Scheinost, A.C.; Hinman, N.W.; Furniss, G.; Mertzman, S.A.; Bishop, J.L.; Ming, D.W.; et al. Mineralogy, composition, and alteration of Mars Pathfinder rocks and soils: Evidence from multispectral, elemental, and magnetic data on terrestrial analogue, SNC meteorite, and Pathfinder samples. J. Geophys. Res. 2000, 105, 1757-1817. [CrossRef]

254. Barrn, V.; Torrent, J. Evidence for a simple pathway to maghemite in Earth and Mars soils. Geochim. Cosmochim. Acta 2002, 66, 2801-2806. [CrossRef]

255. Ricardo, A.; Carrigan, M.A.; Olcott, A.; Benner, S.A. Borate minerals stabilize ribose. Science 2004, 303, 196. [CrossRef] 
256. Scorei, R.; Cimpoiaşu, V.M. Boron enhances the thermostability of carbohydrates. Orig. Life Evol. Biosph. 2006, 36, 1-11. [CrossRef]

257. Furukawa, Y.; Horiuchi, M.; Kakegawa, T. Selective stabilization of ribose by borate. Orig. Life Evol. Biosph. 2013, 43, 353-361. [CrossRef]

258. Gasda, P.J.; Haldeman, E.B.; Wiens, R.C.; Rapin, W.; Bristow, T.F.; Bridges, J.C.; Schwenzer, S.P.; Clark, B.; Herkenhoff, K.; Frydenvang, J.; et al. In situ detection of boron by ChemCam on Mars. Geophys. Res. Lett. 2017, 44, 8739-9748. [CrossRef]

259. Stephenson, J.D.; Hallis, L.J.; Nagashima, K.; Freeland, S.J. Boron enrichment in Martian clay. PLoS ONE 2013, 8, e64624. [CrossRef]

260. Das, D.; Gasda, P.J.; Wiens, R.C.; Berlo, K.; Leveille, R.J.; Frydenvang, J.; Mangold, N.; Kronyak, R.E.; Schwenzer, S.P.; Forni, O.; et al. Boron and lithium in calcium sulfate veins: Tracking precipitation of diagenetic materials in Vera Rubin ridge, Gale crater. JGR Planets 2020, 125, e2019JE006301. [CrossRef]

261. Eglinton, G.; Logan, G.A.; Ambler, R.P.; Boon, J.J.; Perizonius, W.R.K. Molecular preservation [and discussion]. Philos. Trans. Biol. Sci. 1991, 333, 315-328.

262. Castañeda, I.S.; Schouten, S. A review of molecular organic proxies for examining modern and ancient lacustrine environments. Quat. Sci. Rev. 2011, 30, 2851-2891. [CrossRef]

263. Sollai, M.; Villanueva, L.; Hopmans, E.C.; Keil, R.G.; Sinninghe Damsté, J.S. Archaeal sources of intact membrane lipid biomarkers in the oxygen deficient zone of the Eastern Tropical South Pacific. Front. Microbiol. 2019, 10, 765. [CrossRef]

264. Lee, C.; Brocks, J.J. Identification of carotane breakdown products in the 1.64 billion year old Barney Creek Formation, McArthur Basin, northern Australia. Org. Geochem. 2011, 42, 425-430. [CrossRef]

265. Summons, R.E.; Welander, P.V.; Gold, D.A. Lipid biomarkers: Molecular tools for illuminating the history of microbial life. Nat. Rev. Microbiol. 2021, 20, 174-185. [CrossRef]

266. Burgos, C.; Ayer, D.; Johnson, R.A. A new, asymmetric synthesis of lipids and phospholipids. J. Org. Chem. 1987, 52, 4973-4977. [CrossRef]

267. Listunov, D.; Fabing, I.; Saffon-Merceron, N.; Gaspard, H.; Volovenko, Y.; Maraval, V.; Chauvin, R.; Génnison, Y. Asymmetric synthesis and biological evaluation of natural or bioinspired cytotoxic C2-symmetrical lipids with two terminal chiral alkynylcarbinol pharmacophores. J. Org. Chem. 2015, 80, 5386-5394. [CrossRef]

268. Mountanea, O.G.; Limnios, D.; Kokotou, M.G.; Bourboula, A.; Kokotos, G. Asymmetric synthesis of saturated hydroxy fatty acids and fatty acid esters of hydroxy fatty acids. Eur. J. Org. Chem. 2019, 2019, 2010-2019. [CrossRef]

269. Altamura, E.; Comte, A.; D’Onofrio, A.D.; Roussillon, C.; Fayolle, D.; Buchet, R.; Mavelli, F.; Stano, P.; Fiore, M.; Strazewski, P. Racemic phospholipids for origin of life studies. Symmetry 2020, 12, 1108. [CrossRef]

270. Des Marais, D.J. Isotopic evolution of the biogeochemical carbon cycle during the Precambrian. Rev. Mineral. Geochem. 2001, 43, 555-578. [CrossRef]

271. Tegelaar, E.W.; Derenne, S.; Largeau, C.; de Leeuw, J.W. A reappraisal of kerogen formation. Geochim. Cosmochim. Acta 1989, 3 , 3103-3107. [CrossRef]

272. Burdige, D. Preservation of organic matter in marine sediments: Controls, mechanisms, and an imbalance in sediment organic carbon budgets? Chem. Rev. 2007, 107, 467-485. [CrossRef]

273. Brocks, J.J.; Summons, R.E. Sedimentary hydrocarbons, biomarkers for early life. In Treatise on Geochemistry, 2nd ed.; Holland, D.H., Turekian, K.K., Eds.; Elsevier: Amsterdam, The Netherlands, 2003; Volume 8, pp. 61-103.

274. Lee, C.; Love, G.D.; Jahnke, L.L.; Kubo, M.D.; Des Marais, D.J. Early diagenetic sequestration of microbial mat lipid biomarkers through covalent binding into insoluble macromolecular organic matter (IMOM) as revealed by sequential chemolysis and catalytic hydropyrolysis. Org. Geochem. 2019, 132, 11-22. [CrossRef]

275. Lee, C.; Love, G.D.; Jahnke, L.L.; Kubo, M.D.; Des Marais, D.J. Diagenetic transformations and preservation of free and bound lipids in a hypersaline microbial mat from Guerrero Negro, Baja California Sur, Mexico. Org. Geochem. 2021, $153,104196$. [CrossRef]

276. Bishop, A.N.; Love, G.D.; McAulay, A.D.; Snape, C.E.; Farrimond, P. Release of kerogen bound hopanoids by hydropyrolysis. Org. Geochem. 1998, 29, 989-1001. [CrossRef]

277. Farrimond, P.; Love, G.D.; Bishop, A.N.; Innes, H.E.; Watson, D.F.; Snape, C.E. Evidence for rapid incorporation of hopanoids into kerogen. Geochim. Cosmochim. Acta 2003, 67, 1383-1394. [CrossRef]

278. Peters, K.E.; Walters, C.C.; Moldowan, J.M. The Biomarker Guide: Biomarkers and Isotopes in Petroleum Exploration and Earth History, 2nd ed.; Cambridge University Press: Cambridge, UK, 2005; Volume 2.

279. Horsfield, B.; Rullkötter, J. Diagenesis, catagenesis, and metagenesis of organic matter. In The Petroleum System-From Source to Trap; Magoon, L.B., Dow, W.G., Eds.; American Association of Petroleum Geologists: Tulsa, OK, USA, 1994; Volume 60. [CrossRef]

280. Durand, B. Sedimentary organic matter and kerogen: Definition and quantitative importance of kerogen. In Kerogen: Insoluble Organic Matter from Sedimentary Rocks; Durand, B., Ed.; Editions Technip: Paris, France, 1980; pp. 13-33.

281. Tissot, B.P.; Welte, D.H. Petroleum Formation and Occurrence, 1st ed.; Springer: Berlin/Heidelberg, Germany, 1984. [CrossRef]

282. Vandenbroucke, M.; Largeau, C. Kerogen origin, evolution and structure. Org. Geochem. 2007, 38, 719-833. [CrossRef]

283. Keil, R.G.; Montluçon, D.B.; Prahl, F.G.; Hedges, J.I. Sorptive preservation of labile organic matter in marine sediments. Nature 1994, 370, 549-552. [CrossRef]

284. Keil, R.G.; Mayer, L.M. Mineral matrices and organic matter. In Treatise on Geochemistry, 2nd ed.; Holland, D.H., Turekian, K.K., Eds.; Elsevier: Amsterdam, The Netherlands, 2014; Volume 12, pp. 337-359. [CrossRef] 
285. Fox, A.C.; Eigenbrode, J.L.; Freeman, K.H. Radiolysis of macromolecular organic material in Mars-relevant mineral matrices. JGR Planets 2019, 124, 3257-3266. [CrossRef]

286. Salmon, V.; Derenne, S.; Lallier-Vergès, E.; Largeau, C.; Beaudoin, B. Protection of organic matter by mineral matrix in a Cenomanian black shale. Org. Geochem. 2000, 31, 463-474. [CrossRef]

287. Love, G.D.; Stalvies, C.; Grosjean, E.; Meredith, W.; Snape, C.E. Analysis of molecular biomarkers covalently bound within Neoproterozoic sedimentary kerogen. In From Evolution to Geobiology: Research Questions Driving Paleontology at the Start of a New Century, Paleontological Society Short Course, Paleontological Society Papers; Kelley, P.H., Bambach, R.K., Eds.; Cambridge University Press: Cambridge, UK, 2008; Volume 14, pp. 67-83. [CrossRef]

288. Kerogen, P.S. Encyclopedia of Geochemistry. Encyclopedia of Earth Sciences Series; White, W.M., Ed.; Springer: Cham, Switzerland, 2018. [CrossRef]

289. Kerridge, J.F. Formation and processing of organics in the early Solar System. Space Sci. Rev. 1999, 290, 275-288. [CrossRef]

290. Tsuchiya, H.; Mizogami, M. Discrimination of stereoisomers by their enantioselective interactions with chiral cholesterolcontaining membranes. Molecules 2018, 23, 49. [CrossRef] [PubMed]

291. Gerst, N.; Ruan, B.; Pang, J.; Wilson, W.K.; Schroepfer, G.J., Jr. An updated look at the analysis of unsaturated C27 sterols by gas chromatography and mass spectrometry. J. Lipid Res. 1997, 38, 1685-1701. [CrossRef]

292. Maxwell, J.R.; Mackenzie, A.S.; Volkman, J.K. Configuration at C-24 in steranes and sterols. Nature 1980, 286, 694-697. [CrossRef]

293. vaan Kaam-Peters, H.M.E.; Köster, J.; van der Gaast, S.J.; Dekker, M.; de Leeuw, J.W.; Sinninghe Damsté, J.S. The effect of clay minerals on diasterane/sterane ratios. Geochim. Cosmochim. Acta 1998, 62, 2923-2929. [CrossRef]

294. Elie, M.; Nogueira, A.C.R.; Nedlec, A.; Trindale, R.I.F.; Kenig, F. A red algal bloom in the aftermath of the Marinoan Snowball Earth. Terra Nova 2007, 19, 303-308. [CrossRef]

295. Tannenbaum, E.; Huizinga, B.J.; Kaplan, I.R. Role of minerals in thermal alteration of organic matter-II: A material balance. Amer. Assoc. Petrol. Geol. Bull. 1986, 70, 1156-1165. [CrossRef]

296. Soldan, A.L.; Cerqueira, J.R. Effects of thermal maturation on geochemical parameters obtained by simulated generation of hydrocarbons. Org. Geochem. 1986, 10, 339-345. [CrossRef]

297. Love, G.D.; Snape, C.E.; Carr, A.D.; Houghton, R.C. Release of covalently-bound alkane biomarkers in high yields from kerogen via catalytic hydropyrolysis. Org. Geochem. 1995, 23, 981-986. [CrossRef]

298. Love, G.D.; Snape, C.E.; Carr, A.D.; Houghton, R.C. Changes in molecular biomarker and bulk carbon skeletal parameters of vitrinite concentrates as a function of rank. Energy Fuels 1996, 10, 149-157. [CrossRef]

299. Love, G.D.; McAulay, A.; Snape, C.E.; Bishop, A.N. Effect of process variables in catalytic hydropyrolysis on the release of Covalently bound aliphatic hydrocarbons from sedimentary organic matter. Energy Fuels 1997, 11, 522-531. [CrossRef]

300. Love, G.D.; Snape, C.E.; Fallick, A.E. Differences in the mode of incorporation and biogenicity of the principal aliphatic constituents of a Type I oil shale. Org. Geochem. 1998, 28, 797-811. [CrossRef]

301. Love, G.D.; Bowden, S.A.; Summons, R.E.; Jahnke, L.L.; Snape, C.E.; Campbell, C.N.; Day, J.G. An optimised catalytic hydropyrolysis method for the rapid screening of microbial cultures for lipid biomarkers. Org. Geochem. 2005, 36, 63-82. [CrossRef]

302. Sudgen, M.A.; Abbott, G.D. The stereochemistry of bound and extractable pentacyclic triterpenoids during closed system pyrolysis. Org. Geochem. 2002, 33, 1515-1521. [CrossRef]

303. Krot, A.N.; Amelin, Y.; Bland, P.; Ciesla, F.J.; Connelly, J.; Davis, A.M.; Huss, G.R.; Hutcheon, I.D.; Makide, K.; Nagashima, K.; et al. Origin and chronology of chondritic components: A review. Geochim. Cosmochim. Acta 2009, 73, 4963-4997. [CrossRef]

304. Cloutis, E.A.; Izawa, M.R.M.; Beck, P. Chapter 4-Reflectance Spectroscopy of Chondrites. In Primitive Meteorites and Asteroids Physical, Chemical and Spectroscopic Observations Paving the Way to Exploration; Abreu, N., Ed.; Elsevier: Amsterdam, The Netherlands, 2018; pp. 273-343. [CrossRef]

305. Krot, A.N.; Keil, K.; Scott, E.R.D.; Goodrich, C.A.; Weisberg, M.K. Classification of meteorites and their genetic relationships. In Treatise on Geochemistry; Holland, D.H., Turekian, K.K., Eds.; Elsevier: Amsterdam, The Netherlands, 2014 ; Volume 1, pp. 1-63.

306. Maurel, C.; Bryson, J.F.J.; Lyons, R.J.; Ball, M.R.; Chopdekar, R.V.; Scholl, A.; Ciesla, F.J.; Bottke, W.F.; Wiess, B.P. Meteorite evidence for partial differentiation and protracted accretion of planetesimals. Sci. Adv. 2014, 6, eaba1303. [CrossRef]

307. Weisberg, M.K.; McCoy, T.J.; Krot, A.N. Systematics and evaluation of meteorite classification. In Meteorites and the early Solar System II; Lauretta, D.S., McSween, H.Y., Jr., Eds.; University of Arizona Press: Tucson, AZ, USA, 2006; pp. 19-52.

308. Wood, J.A. Chondritic meteorites and the solar nebula. Ann. Rev. Earth Planet. Sci. 1988, 16, 53-72. [CrossRef]

309. Braukmüller, N.; Wombacher, F.; Hezel, D.C.; Escoube, R.; Münker, C. The chemical composition of carbonaceous chondrites: Implications for volatile element depletion, complementarity and alteration. Geochim. Cosmochim. Acte 2018, 239, 17-48. [CrossRef]

310. Van Schmus, W.R.; Wood, J.A. A chemical-petrologic classification for the chondritic meteorites. Geochim. Cosmochim. Acta 1967, 31, 747-754. [CrossRef]

311. Grimm, R.E.; McSween, H.Y., Jr. Water and the thermal evolution of carbonaceous chondrite parent bodies. Icarus 1989, 82, 244-280. [CrossRef]

312. Brearley, A.J.; Jones, R.H. Chondritic meteorites. In Planetary Materials; Papike, J.J., Ed.; De Gruyter: Berlin, Germany, 1998; Volume 36, pp. 3.1-3.398. [CrossRef]

313. Scott, E.R.D.; Krot, A.N. Chondrites and their components. In Meteorites, Comets and Planets: Treatise on Geochemistry; Davis, A.M., Holland, H.D., Turekian, K.K., Eds.; Elsevier, B.V.: Amsterdam, The Netherlands, 2005; Volume 1, p. 143.

314. Scott, E.R. Chondrites and the protoplanetary disk. Annu. Rev. Earth Planet. Sci. 2007, 35, 577-620. [CrossRef] 
315. Hiroi, T.; Pieters, C.M.; Zolensky, M.; Lipschutz, M.E. Evidence of thermal metamorphism on the C, G, B, and F asteroids. Science 1993, 261, 1016-1018. [CrossRef] [PubMed]

316. Huss, G.R.; Rubin, A.E.; Grossman, J.N. Thermal metamorphism in chondrites. In Meteorites and the early Solar System II; Lauretta, D.S., McSween, H.Y., Jr., Eds.; University of Arizona Press: Tucson, AZ, USA, 2006; pp. 567-586.

317. Gyollai, I.; Bérczi, S.; Fintor, K.; Nagy, S.; Gucsik, A. Thermal metamorphism of the Mócs meteorite (L6) revealed by optical microscopy and BSE imaging. Cent. Eur. Geol. 2015, 58, 321-333. [CrossRef]

318. King, A.J.; Schofield, P.F.; Russell, S.S. Thermal alteration of CM carbonaceous chondrites: Mineralogical changes and metamorphic temperatures. Geochim. Cosmochim. Acta 2021, 298, 167-190. [CrossRef]

319. Yesiltas, M.; Young, J.; Glotch, T.D. Thermal metamorphic history of Antarctic CV3 and CO3 chondrites inferred from the firstand second-order Raman peaks of polyaromatic organic carbon. Am. Miner. 2021, 106, 506-517. [CrossRef]

320. Kallemeyn, G.W.; Rubin, A.E.; Wasson, J.T. The compositional classification of chondrites: VI. The CR carbonaceous chondrite group. Geochim. Cosmochim. Acta 1994, 58, 2873-2888. [CrossRef]

321. Amelin, Y.; Ghosh, A.; Rotenberg, E. Unraveling the evolution of chondrite parent asteroids by precise U-Pb dating and thermal modeling. Geochim. Cosmochim. Acta 2005, 69, 505-518. [CrossRef]

322. Goldstein, J.I.; Scott, E.R.D.; Chabot, N.L. Iron meteorites: Crystallization, thermal history, parent bodies, and origin. Chem. Der Erde 2009, 69, 293-325. [CrossRef]

323. Yang, J.; Goldstein, J.I.; Michael, J.R.; Kotula, P.G.; Scott, E.R.D. Thermal history and origin of the IVB iron meteorites and their parent body. Geochim. Cosmochim. Acta 2010, 74, 4493-4506. [CrossRef]

324. Henke, S.; Gail, H.-P.; Trieloff, M.; Schwarz, W.H.; Kleine, T. Thermal history modelling of the H chondrite parent body. Astron. Astrophys. 2012, 545, A135. [CrossRef]

325. Gail, H.-P.; Trieloff, M. Thermal history modelling of the L chondrite parent body. Astron. Astrophys. 2019, 628, 1-21. [CrossRef]

326. Brearley, A.J. The action of water. In Meteorites and the early Solar System II; Lauretta, D.S., McSween, H.Y., Jr., Eds.; University of Arizona Press: Tucson, AZ, USA, 2006; pp. 587-624.

327. Doyle, P.M.; Jogo, K.; Nagashima, K.; Krot, A.N.; Wakita, S.; Ciesla, F.J. Early aqueous activity on the ordinary and carbonaceous chondrite parent bodies recorded by fayalite. Nat. Commun. 2015, 6, 7444. [CrossRef] [PubMed]

328. Endress, M.; Bischoff, A. Carbonates in CI chondrites: Clues to parent body evolution. Geochim. Cosmochim. Acta 1996, 60, 489-507. [CrossRef]

329. Endress, M.; Zinner, E.; Bischoff, A. Early aqueous activity on primitive meteorite parent bodies. Nature 1996, 379, 701-703. [CrossRef]

330. Berger, E.L.; Zega, T.L.; Keller, L.P.; Lauretta, D.S. Evidence for aqueous activity on comet 81 P/Wild 2 from sulfide mineral assemblages in Stardust samples and CI chondrites. Geochim. Cosmochim. Acta 2011, 75, 3501-3513. [CrossRef]

331. Berger, E.L.; Keller, L.P.; Lauretta, D.S. An experimental study of the formation of cubanite $\left(\mathrm{CuFe}_{2} \mathrm{~S}_{3}\right)$ in primitive meteorites. Meteorit. Planet. Sci. 2015, 50,1-14. [CrossRef]

332. Sarafian, A.R.; Nielsen, S.G.; Marshall, H.R.; Gaetani, G.A.; Righter, K.; Berger, E.L. The water and fluorine content of 4 Vesta. Geochim. Cosmochim. Acta 2019, 266, 568-581. [CrossRef]

333. Kojima, T.; Tomeoka, K. Indicators of aqueous alteration and thermal metamorphism on the CV parent body: Microtextures of a dark inclusion from Allende. Geochim. Cosmochim. Acta 1996, 60, 2651-2666. [CrossRef]

334. Kikuchi, S.; Shibuya, T.; Abe, M.; Uematsu, K. Experimental chondrite-water reactions under reducing and low-temperature hydrothermal conditions: Implications for incipient aqueous alteration in planetesimals. Geochim. Comsochim. Acta, 2021, in press. [CrossRef]

335. Dyl, K.A.; Bischoff, A.; Ziegler, K.; Young, E.D.; Wimmer, K.; Bland, P.A. Early Solar System hydrothermal activity in chondritic asteroids on 1-10-year timescales. Proc. Natl. Acad. Sci. USA 2012, 109, 18306-18311. [CrossRef]

336. Putnis, A.; Austrheim, H. Fluid-induced processes: Metasomatism and metamorphism. Geofluids 2010, 10, 245-269. [CrossRef]

337. Yasui, M.; Tazawa, T.; Hashimoto, R.; Arakawa, M.; Ogawa, K. Impacts may provide heat for aqueous alteration and organic solid formation on asteroid parent bodies. Commun. Earth Environ. 2021, 2, 95. [CrossRef]

338. Hirakawa, N.; Kebukawa, Y.; Furukawa, Y.; Kondo, M.; Nakano, H.; Kobayashi, K. Aqueous alteration without initial water: Possibility of organic-induced hydration of anhydrous silicates in meteorite parent bodies. Earth Planets Space 2021, 73, 16. [CrossRef]

339. Scott, E.R.D.; Keil, K.; Stoffler, D. Shock metamorphism of carbonaceous chondrites. Geochim. Cosmochim. Acta 1992, 56, 4281-4293. [CrossRef]

340. Sharp, T.G.; DeCarli, P.S. Shock effects in meteorites. In Meteorites and the Early Solar System II; Lauretta, D.S., McSween, H.Y., Jr., Eds.; University of Arizona Press: Tucson, AZ, USA, 2006; pp. 653-677.

341. Bischoff, A.; Scott, E.R.D.; Metzler, K.; Goodrich, C.A. Nature and origins of meteoritic breccias. In Meteorites and the Early Solar System II; Lauretta, D.S., McSween, H.Y., Jr., Eds.; University of Arizona Press: Tucson, AZ, USA, 2006; pp. 679-712.

342. Glavin, D.P.; Alexander, C.M.O.D.; Aponte, J.C.; Dworkin, J.P.; Elsila, J.E.; Yabuta, H. Chapter 3: The origin and evolution of organic matter in carbonaceous chondrites and links to their parent bodies. In Primitive Meteorites and Asteroids: Physical, Chemical and Spectroscopic Observations Paving the Way to Exploration; Abreu, N., Ed.; Elsevier: Amsterdam, The Netherlands, 2018; pp. 205-271. [CrossRef] 
343. Callahan, M.P.; Smith, K.E.; Cleaves, J., II; Ruzicka, J.; Stern, J.C.; Glavin, D.P.; House, C.H.; Dworkin, J.P. Carbonaceous meteorites contain a wide range of extraterrestrial nucleobases. Proc. Natl. Acad. Sci. USA 2011, 108, 13995-13998. [CrossRef] [PubMed]

344. Burton, A.S.; Stern, J.C.; Elsila, J.E.; Glavin, D.P.; Dworkin, J.P. Understanding prebiotic chemistry through the analysis of extraterrestrial amino acids and nucleobases in meteorites. Chem. Soc. Rev. 2012, 41, 5459-5472. [CrossRef]

345. Elsila, J.E.; Aponte, J.C.; Blackmond, D.G.; Burton, A.S.; Dworkin, J.P.; Glavin, D.P. Meteoritic amino acids: Diversity in compositions reflects parent body histories. ACS Cent. Sci. 2016, 2, 370-379. [CrossRef]

346. Glavin, D.P.; McLain, H.L.; Dworkin, J.P.; Parker, E.T.; Elsila, J.E.; Aponte, J.C.; Simkus, D.N.; Pozarycki, C.I.; Graham, H.V.; Nittler, L.R.; et al. Abundant extraterrestrial amino acids in the primitive CM carbonaceous chondrite Asuka 12236. Meteorit. Planet. Sci. 2020, 55, 1979-2006. [CrossRef]

347. Sephton, M.A. Organic compounds in carbonaceous chondrites. Nat. Prod. Rep. 2002, 19, 292-311. [CrossRef]

348. Ehrenfreund, P.; Glavin, D.P.; Botta, O.; Cooper, G.; Bada, J.L. Extraterrestrial amino acids in Orgueil and Ivuna: Tracing the parent body of CI type carbonaceous chondrites. Proc. Natl. Acad. Sci. USA 2001, 98, 2138-2141. [CrossRef]

349. Wächtershäuser, G. Pyrite formation, the first energy source for life: A hypothesis. Syst. Appl. Microbiol. 1988, 10, 207-210. [CrossRef]

350. Wächtershäuser, G. Groundworks for an evolutionary biochemistry: The iron-sulphur world. Prog. Biophys. Mol. Biol. 1992, 58, 85-201. [CrossRef]

351. Huber, C.; Wächtershäuser, G. $\alpha$-hyydroxy and $\alpha$-amino acids under possible Hadean, volcanic origin-of-life conditions. Science 2006, 314, 630-632. [CrossRef]

352. Yadav, M.; Kumar, R.; Krishnamurthy, R. Chemistry of abiotic nucleotide synthesis. Chem. Rev. 2020, 120, 4766-4805. [CrossRef]

353. Weber, J.M.; Henderson, B.L.; LaRowe, D.E.; Goldman, A.D.; Perl, S.M.; Billings, K.; Barge, L.M. Testing abiotic reduction of NAD+ directly mediated by iron/sulfur minerals. Astrobiology 2021, 22, 25-34. [CrossRef]

354. Nguyen, L.A.; He, H.; Pham-Huy, C. Chiral drugs: An overview. Int. J. Biomed. Sci. 2006, 2, 85-100.

355. Bruylants, G.; Wouters, J.; Michaux, C. Differential scanning calorimetry in life science: Thermodynamics, stability, molecular recognition and application in drug design. Curr. Med. Chem. 2005, 12, 2011-2020. [CrossRef]

356. Gil-Av, E.; Feibush, B.; Charles-Sigler, R. Separation of enantiomers by gas liquid chromatography with an optically active stationary phase. Tetrahedron Lett. 1966, 7, 1009-1015. [CrossRef]

357. Grybinik, S.; Bosakova, Z. An overview of chiral separations of pharmaceutically active substances by HPLC (2018-2020). Mon. Chem. Chem. Mon. 2021, 152, 1033-1043. [CrossRef]

358. Labuta, J.; Ishihara, S.; Šikorský, T.; Futera, Z.; Shundo, A.; Hanyková, L.; Burda, J.V.; Ariga, K.; Hill, J.P. NMR spectroscopic detection of chirality and enantiopurity in referenced systems without formation of diastereomers. Nat. Commun. 2013, 4, 2188. [CrossRef]

359. Gottarelli, G.; Osipov, M.A.; Spada, G.P. A study of solvent effect on the optical rotation of chiral biaryls. J. Phys. Chem. 1991, 95, 3879-3884. [CrossRef]

360. Langeveld-Voss, B.M.W.; Christiaans, M.P.T.; Janssen, R.A.J.; Meijer, E.W. Inversion of optical activity of chiral polythiophene aggregates by a change of solvent. Macromolecules 1998, 31, 6702-6704. [CrossRef]

361. Thiemann, W.H.-P.; Rosenbauer, H.; Meierhenrich, U.J. Conception of the 'chirality-experiment' on ESA's mission ROSETTA to comet P46/Wirtanen. Adv. Space Res. 2001, 27, 323-328. [CrossRef]

362. Freissinet, C.; Buch, A.; Sternberg, R.; Szopa, C.; Geffroy-Rodier, C.; Jelinek, C.; Stambouli, M. Search for evidence of life in space: Analysis of enantiomeric organic molecules by $\mathrm{N}, \mathrm{N}$-dimethylformamide dimethylacetal derivative dependant gas chromatography-mass spectrometry. J. Chromatogr. A 2010, 1217, 731-740. [CrossRef]

363. Mahaffy, P.R.; Webster, C.R.; Cabane, M.; Conrad, P.G.; Coll, P.; Atreya, S.K.; Arvey, R.; Barciniak, M.; Benna, M.; Bleacher, L.; et al. The Sample Analysis at Mars Investigation and Instrument Suite. Space Sci. Rev. 2012, 170, 401-478. [CrossRef]

364. Goesmann, F.; Brinckerhoff, W.B.; Raulin, F.; Goetz, W.; Danell, R.M.; Getty, S.A.; Siljeström, S.; Mißbach, H.; Steininger, H.; Arevalo, R.D., Jr.; et al. The Mars Organic Molecule Analyzer (MOMA) instrument: Characterization of organic material in Martian sediments. Astrobiology 2017, 17, 655-685. [CrossRef] [PubMed]

365. Ulamec, S.; Goesmann, F.; Meierhenrich, U.J. Philae landing on comet 67P/Churyumov-Gerasimenko-Planned chirality measurements and ideas for the future. J. Interdiscip. Methodol. Issues Sci. 2018, 4, 1-11. [CrossRef]

366. Sousa, E.P.; Tiritan, M.E.; Oliveira, R.; Afonso, C.M.M.; Cass, Q.B.; Pinto, M.M.M. Enantiomeric resolution of kielcorin derivatives by HPLC on polysaccharide stationary phases using multimodal elution. Chirality 2004, 16, 279-285. [CrossRef]

367. Dossou, K.S.S.; Chiap, P.; Servais, A.C.; Fillet, M.; Crommen, J. Evaluation of chlorine containing cellulose-based chiral stationary phases for the LC enantioseparation of basic pharmaceuticals using polar non-aqueous mobile phases. J. Sep. Sci. 2011, 34, 617-622. [CrossRef]

368. Ianni, F.; Saluti, G.; Galarini, R.; Fiorito, S.; Sardella, R.; Natalini, B. Enantioselective high-performance liquid chromatography analysis of oxygenated polyunsaturated fatty acids. Free Radic. Biol. Med. 2019, 144, 35-54. [CrossRef]

369. Mangelings, D.; Vander Heyden, Y. Chiral separations in sub- and supercritical fluid chromatography. J. Sep. Sci. 2008, 31, 1252-1273. [CrossRef]

370. West, C. Enantioselective separations with supercritical fluid-Review. Curr. Anal. Chem. 2014, 10, 99-120. [CrossRef]

371. Gübitz, G.; Schmid, M.G. Chiral separation principles in capillary electrophoresis. J. Chromatogr. A 1997, 792, 179-225. [CrossRef] 
372. Mathies, R.A.; Razu, M.E.; Kim, J.; Stockton, A.M.; Turin, P.; Butterworth, A. Feasibility of detecting bioorganic compounds in Enceladus plumes with the Enceladus Organic Analyzer. Astrobiology 2017, 17, 902-912. [CrossRef]

373. Zamuruyev, K.; Santos, M.S.F.; Mora, M.F.; Kurfman, E.A.; Noell, A.C.; Willis, P.A. Automated capillary electrophoresis system compatible with multiple detectors for potential in situ spaceflight missions. Anal. Chem. 2021, 93, 9647-9655. [CrossRef]

374. Gübitz, G.; Schmid, M.G. Chiral separation by capillary electrochromatography. Enantiomer 2000, 5, 5-11.

375. Wistuba, D.; Schurig, V. Recent progress in enantiomer separation by capillary electrochromatography. Electrophoresis 2000, 21, 4136-4158. [CrossRef]

376. Fanali, C.; Della Posta, S.; Fanali, S. Capillary electrochromatography applied to drug analysis. J. Chromatogr. Open 2021, 1, 100015. [CrossRef]

377. Kodama, S.; Yamamoto, A.; Iio, R.; Sakamoto, K.; Matsunaga, A.; Hayakawa, K. Chiral ligand exchange capillary electrophoresis using borate anion as a central ion. Analyst 2004, 129, 1238-1242. [CrossRef]

378. Mu, X.; Qi, L.; Shen, Y.; Zhang, H.; Qiao, J.; Ma, H. A novel chiral ligand exchange capillary electrophoresis system with amino acid ionic liquid as ligand and its application in screening d-amino-acid oxidase inhibitors. Analyst 2012, 137, 4235-4240. [CrossRef]

379. Liu, L.; Bao, P.; Qiao, J.; Zhang, H.; Qi, L. Chiral ligand exchange capillary electrophoresis with L-dipeptides as chiral ligands for separation of Dns-D.,L-amino acids. Talanta 2020, 217, 121069. [CrossRef]

380. Wang, F.; Khaledi, M.G. Chiral separations by nonaqueous capillary electrophoresis. Anal. Chem. 1996, 68, 3460-3467. [CrossRef] [PubMed]

381. Limero, T.; Reese, E.; Trowbridge, J.; Hohman, R.; James, J.T. The Volatile Organic Analyzer (VOA) aboard the International Space Station; SAE Technical Paper 2002-01-2407; SAE International: Warrendale, PA, USA, 2002. [CrossRef]

382. Dwivedi, P.; Wu, C.; Matz, L.M.; Clowers, B.H.; Siems, W.F.; Hill, H.H., Jr. Gas-phase chiral separations by ion mobility spectrometry. Anal. Chem. 2006, 78, 8200-8206. [CrossRef] [PubMed]

383. Mie, A.; Jörntén-Karlsson, M.; Axelsson, B.-O.; Ray, A.; Reimann, C.T. Enantiomer separation of amino acids by complexation with chiral reference compounds and high-field asymmetric waveform ion mobility spectrometry: Preliminary results and possible limitations. Anal. Chem. 2007, 79, 2850-2858. [CrossRef]

384. Will, J.M.L.; Behrens, A.; Macke, M.; Derrick Quales, C., Jr.; Karst, U. Automated chiral analysis of amino acids based on chiral derivatization and trapped ion mobility-mass spectrometry. Anal. Chem. 2021, 93, 878-885. [CrossRef]

385. Brodbelt, J.S. Photodissociation mass spectrometry: New tools for characterization of biological molecules. Chem. Soc. Rev. 2014, 43, 2757-2783. [CrossRef] [PubMed]

386. Fujihara, A.; Maeda, N.; Doan, T.N.; Hayakawa, S. Enantiomeric excess determination for monosaccharides using chiral transmission to cold gas-phase tryptophan in ultraviolet photodissociation. J. Am. Soc. Mass Spectrom. 2017, 28, 224-228. [CrossRef] [PubMed]

387. Shi, Y.; Zhou, M.; Zhang, K.; Ma, L.; Kong, X. Chiral differentiation of non-covalent diastereomers based on multichannel dissociation induced by 213-nm ultraviolet photodissociation. J. Am. Soc. Mass Spectrom. 2019, 30, 2297-2305. [CrossRef]

388. Koehbach, J.; Gruber, C.W.; Becker, C.; Kreil, D.P.; Jilek, A. MALDI TOF/TOF-based approach for the identification of D-amino acids in biologically active peptides and proteins. J. Proteome Res. 2016, 15, 1487-1496. [CrossRef]

389. Casy, A.F.; Mercer, A.D. Application of cyclodextrins to chiral analysis by 1 H NMR spectroscopy. Magn. Reson. Chem. 1988, 26, 765-774. [CrossRef]

390. Kubo, Y.; Maeda, S.; Tokita, S.; Kubo, M. Colorimetric chiral recognition by a molecular sensor. Nature 1996, 382, 522-524. [CrossRef]

391. Tsubaki, K.; Nuruzzaman, M.; Kusumoto, T.; Hayashi, N.; Bin-Gui, W.; Fuji, K. Visual enantiomeric recognition using chiral phenolphthalein derivatives. Org. Lett. 2001, 3, 4071-4073. [CrossRef]

392. Wirz, R.; Bürgi, T.; Baiker, A. Probing enantiospecific interactions at chiral solid-liquid interfaces by absolute configuration modulation infrared spectroscopy. Langmuir 2003, 19, 785-792. [CrossRef]

393. Hinsmann, P.; Arce, L.; Svasek, P.; Lämmerhofer, M.; Lendl, B. Separation and on-line distinction of enantiomers: A non-aqueous capillary electrophoresis Fourier transform infrared spectroscopy study. Appl Spectrosc. 2004, 58, 662-666. [CrossRef]

394. Giorgio, E.; Viglione, R.G.; Zanasi, R.; Rosini, C. Ab initio calculation of optical rotatory dispersion (ORD) curves: A simple and reliable approach to the assignment of the molecular absolute configuration. J. Am. Chem. Soc. 2004, 126, 12968-12976. [CrossRef]

395. Qiu, S.; De Gussem, E.; Tehrani, K.A.; Sergeyev, S.; Bultinck, P.; Herrebout, W. Stereochemistry of the Tadalafil diastereoisomers: A critical assessment of vibrational circular dichroism, electronic circular dichroism, and optical rotatory dispersion. J. Med. Chem. 2013, 56, 8903-8914. [CrossRef]

396. Beaulieu, S.; Comby, A.; Descamps, D.; Fabre, B.; Garcia, G.A.; Géneaux, R.; Harvey, A.G.; Légaré, F.; Mašín, Z.; Nahon, L.; et al. Photoexcitation circular dichroism in chiral molecules. Nat. Phys. 2018, 14, 484-489. [CrossRef]

397. Kneer, L.M.; Roller, E.-M.; Besteiro, L.V.; Schreiber, R.; Govorov, A.O.; Liedl, T. Circular dichroism of chiral molecules in DNA-assembled plasmonic hotspots. ACS Nano 2018, 12, 9110-9115. [CrossRef]

398. Vestler, D.; Ben-Moshe, A.; Markovich, G. Enhancement of circular dichroism of a chiral Material by dielectric nanospheres. J. Phys. Chem. C 2019, 123, 5017-5022. [CrossRef]

399. Bégin, J.-L.; Alsaawy, M.; Bhardwaj, R. Chiral discrimination by recollision enhanced femtosecond laser mass spectrometry. Sci. Rep. 2020, 10, 14074. [CrossRef] 
400. Sparks, W.; Hough, J.H.; Germer, T.; Robb, F.; Kolokolova, L. Remote sensing of chiral signatures on Mars. Planet. Space Sci. 2012, 72, 111-115. [CrossRef]

401. Sofikitis, D.; Bougas, L.; Katsoprinakis, G.E.; Spiliotis, A.K.; Loppinet, B.; Rakitzis, T.P. Evanescent-wave and ambient chiral sensing by signal-reversing cavity ringdown polarimetry. Nature 2014, 514, 76-79. [CrossRef] [PubMed]

402. Li, L.; Wang, J.; Kang, L.; Liu, W.; Yu, L.; Zheng, B.; Brongersma, M.L.; Werner, D.H.; Lan, S.; Shi, Y.; et al. Monolithic full-Stokes near-infrared polarimetry with chiral plasmonic metasurface integrated graphene-silicon photodetector. ACS Nano 2020, 14, 16634-16642. [CrossRef] [PubMed]

403. Risley, D.S.; Strege, M.A. Chiral separations of polar compounds by hydrophilic interaction chromatography with evaporative light scattering detection. Anal. Chem. 2000, 72, 1736-1739. [CrossRef]

404. Zhang, T.; Nguyen, D.; Franco, P. Use of evaporative light scattering detector in the detection and quantification of enantiomeric mixtures by HPLC. J. Sep. Sci. 2006, 29, 1517-1524. [CrossRef] [PubMed]

405. Bradshaw, D.S.; Andrews, D.L. Laser optical separation of chiral molecules. Opt. Lett. 2015, 40, 677-680. [CrossRef] [PubMed]

406. Solomon, M.L.; Saleh, A.A.E.; Poulikakos, L.V.; Abendroth, J.M.; Tadesse, L.F.; Dionne, J.A. Nanophotonic platforms for chiral sensing and separation. Acc. Chem. Res. 2020, 53, 588-598. [CrossRef] [PubMed]

407. Cook, C.; Bryne, S.; Drouet d'Aubigny, C.; Viola, D.; Mikucki, J.; Ellis, W. Detection limits for chiral amino acids using a polarization camera. Planet. Sci. J. 2020, 1, 46. [CrossRef]

408. Chiu, M.H.; Prenner, E.J. Differential scanning calorimetry: An invaluable tool for a detailed thermodynamic characterization of macromolecules and their interactions. J. Pharm. Bioallied Sci. 2011, 3, 39-59. [CrossRef]

409. Marcellos, C.F.C.; Durand, H.; Kwon, J.S.; Barreto, A.G., Jr.; da Cunha Lage, P.L.; de Souza, M.B., Jr.; Secchi, A.R.; Christofides, P.D. Optimal enantiomer crystallization operation using ternary diagram information. Comput. Aided Chem. Eng. 2018, 44, $499-504$. [CrossRef]

410. Lam, W.H.; Ng, K.M. Diastereomeric salt crystallization synthesis for chiral resolution of ibuprofen. AIChE J. 2007, 53, 429-437. [CrossRef]

411. Pham, X.-H.; Kim, J.-M.; Chang, S.-M.; Kim, I.; Sim, W.K. Enantioseparation of D/L-mandelic acid with L-phenylalanine in diastereomeric crystallization. J. Mol. Catal. B Enzym. 2009, 60, 87-92. [CrossRef]

412. Simon, M.; Wood, B.; Ferguson, S.; Glennon, B.; Jones, R.C. Diastereomeric salt crystallization of chiral molecules via sequential coupled-Batch operation. AIChE J. 2018, 65, 604-616. [CrossRef]

413. Robinson, D.E.J.E.; Bull, S.D. Kinetic resolution strategies using non-enzymatic catalysts. Tetrahedron Asymmetry 2003, 14, 1407-1446. [CrossRef]

414. Mousaw, P.; Saranteas, K.; Prytko, B. Crystallization improvements of a diastereomeric kinetic resolution through understanding of secondary nucleation. Org. Process Res. Dev. 2008, 12, 243-248. [CrossRef]

415. Imayoshi, A.; Lakshmi, B.V.; Ueda, Y.; Yoshimura, T.; Matayoshi, A.; Furuta, T.; Kawabata, T. Enantioselective preparation of mechanically planar chiral rotaxanes by kinetic resolution strategy. Nat. Commun. 2021, 12, 404. [CrossRef]

416. Skelley, A.M.; Mathies, R.A. Chiral separation of fluorescamine-labeled amino acids using microfabricated capillary electrophoresis devices for extraterrestrial exploration. J. Chromatogr A 2003, 1021, 191-199. [CrossRef]

417. Pu, L. Fluorescence of organic molecules in chiral recognition. Chem. Rev. 2004, 104, 1687-1716. [CrossRef]

418. Ohrui, H.; Kato, R.; Kodaira, T.; Shimizu, H.; Akasaka, K.; Kitahara, T. Development of highly potent D-glucosamine-based chiral fluorescent labeling reagents and a microwave-assisted beta-selective glycosidation of a methyl glycoside reagent. Biosci. Biotechnol. Biochem. 2005, 69, 1054-1057. [CrossRef]

419. Wei, W.; Qu, K.; Ren, J.; Qu, X. Chiral detection using reusable fluorescent amylose-functionalized graphene. Chem. Sci. 2011, 2, 2050-2056. [CrossRef]

420. Creamer, J.S.; Mora, M.F.; Noell, A.C.; Willis, P.A. Long-term thermal stability of fluorescent dye used for chiral amino acid analysis on future spaceflight missions. Electrophoresis 2019, 40, 3117-3122. [CrossRef]

421. Miller, S.L.; Van Trump, J.E. The Strecker synthesis in the primitive ocean. In Origin of Life; Wolman, Y., Ed.; Springer: Dordrecht, The Netherlands, 1981; pp. 135-141. [CrossRef]

422. Rodriguez, L.E.; Altari, T.; Hermis, N.Y.; Jia, T.Z.; Roche, T.P.; Steller, L.H.; Weber, J.M. Astrobiology Primer 3.0 Chapter 4: A geological and chemical context for the origins of life on early Earth. Astrobiology, 2022, in review.

423. Butlerov, A. Bildung einer zuckerartigen Substanz durch Synthese. Liebigs Ann. Chem. 1861, 120, 295-298. [CrossRef]

424. Sharma, M.; Mangas-Sanchez, J.; Turner, N.J.; Grogan, G. NAD(P)H-dependent dehydrogenases for the asymmetric reductive amination of ketones: Structure, mechanism, evolution and application. Adv. Synth. Catal. 2017, 359, 2011-2025. [CrossRef]

425. Stubbs, R.T.; Yadav, M.; Krishnamurthy, R.; Springsteen, G. A plausible metal-free ancestral analogue of the Krebs cycle composed entirely of $\alpha$-ketoacids. Nat. Chem. 2020, 12, 1016-1022. [CrossRef]

426. Kumar, A.; Sharma, S.; Maurya, R.A. Single nucleotide-catalyzed biomimetic reductive amination. Adv. Synth. Catal. 2010, 352, 2227-2232. [CrossRef]

427. Storer, R.I.; Carrera, D.E.; Ni, Y.; MacMillan, D.W.C. Enantioselective organocatalytic reductive amination. J. Am. Chem. Soc. 2006, 128, 84-86. [CrossRef]

428. Tripathi, R.P.; Verma, S.S.; Pandey, J.; Tiwari, V.K. Recent development on catalytic reductive amination and applications. Curr. Org. Chem. 2008, 12, 1092-1115. [CrossRef] 
429. Afanasyev, O.I.; Kuchuk, E.; Usanov, D.L.; Chusov, D. Reductive amination in the synthesis of pharmaceuticals. Chem. Rev. 2019, 119, 11857-11911. [CrossRef]

430. Strecker, A. Ueber einen neuen aus Aldehyd-Ammoniak und Blausäure entstehenden Körper. Justus Liebigs Ann. Der Chem. 1854, 91, 349-351. [CrossRef]

431. Harada, K. Asymmetric synthesis of $\alpha$-amino-acids by the Strecker synthesis. Nature 1963, 200, 1201. [CrossRef]

432. Gröger, H. Catalytic enantioselective Strecker reactions and analogous syntheses. Chem. Rev. 2003, 103, 2795-2828. [CrossRef] [PubMed]

433. Krishnamurthy, R.; Pulletikurti, S.; Yadav, M.; Springsteen, G. Prebiotic synthesis of $\alpha$-amino acids and orotate from $\alpha$-ketoacids potentiates transition to extant metabolic pathways. Res. Sq. 2021, in review. [CrossRef]

434. Davis, F.A.; Reddy, R.E.; Portonovo, P.S. Asymmetric strecker synthesis using enantiopure sulfinimines: A convenient synthesis of $\alpha$-amino acids. Tetrahedron Lett. 1994, 35, 9351-9354. [CrossRef]

435. Iyer, M.S.; Gigstad, K.M.; Namdev, N.D.; Lipton, M. Asymmetric catalysis of the Strecker amino acid synthesis by a cyclic dipeptide. Amino Acids 1996, 11, 259-268. [CrossRef]

436. Aiba, S.; Takamatsu, N.; Sasai, T.; Tokunaga, Y.; Kawasaki, T. Replication of $\alpha$-amino acids via Strecker synthesis with amplification and multiplication of chiral intermediate aminonitriles. Chem. Commun. 2016, 52, 10834-10837. [CrossRef]

437. Miyagawa, S.; Yoshimura, K.; Yamazaki, Y.; Takamatsu, N.; Kuraish, T.; Aiba, S.; Tokunaga, Y.; Kawasaki, T. Asymmetric Strecker reaction arising from the molecular orientation of an achiral imine at the single-crystal face: Enantioenriched L- and D-amino acids. Angew. Chem. Int. Ed. 2016, 56, 1055-1058. [CrossRef]

438. Legnani, L.; Darù, A.; Jones, A.X.; Blackmond, D.G. Mechanistic insight into the origin of stereoselectivity in the ribose-mediated Strecker synthesis of alanine. J. Am. Chem. Soc. 2021, 143, 7852-7858. [CrossRef]

439. Jeilani, Y.A.; Nguyen, M.T. Autocatalysis in formose reaction and formation of RNA nucleosides. J. Phys. Chem. B 2020, 124, 11324-11336. [CrossRef]

440. Cleaves, H.J. Formose reaction. In Encyclopedia of Astrobiology; Gargaud, M., Irvine, W.M., Amils, R., Cleaves, H.J., II, Pinti, D.L., Quintanilla, J.C., Rouan, D., Spohn, T., Tirard, S., Viso, M., Eds.; Springer: Berlin/Heidelberg, Germany, 2011. [CrossRef]

441. Fialho, D.M.; Clarke, K.C.; Moore, M.K.; Schuster, G.B.; Krishnamurthy, R.; Hud, N.V. Glycosylation of a model proto-RNA nucleobase with non-ribose sugars: Implications for the prebiotic synthesis of nucleosides. Org. Biomol. Chem. 2018, 16, 1263-1271. [CrossRef]

442. Omran, A.; Menor-Salvan, C.; Springsteen, G.; Pasek, M. The messy alkaline formose reaction and its link to metabolism. Life 2020, 10, 125. [CrossRef]

443. Mizuno, T.; Mori, T.; Shiomi, N.; Nakatsuji, H. Studies on synthesis and utilization of formose Part I. J. Agric. Chem. Soc. Jpn. 1970, 44, 324-331. [CrossRef]

444. Shigemasa, Y.; Nagae, O.; Sakazawa, C.; Nakashima, R.; Matsuura, T. Formose reactions. 5. A selective formose reaction. J. Am. Chem. Soc. 1978, 100, 1309-1310. [CrossRef]

445. SMatsumoto, T.; Inoue, S. Formose reactions. Part 3. Selective formose reaction catalyzed by organic bases. J. Chem. Soc. Perkin Trans. 1982, 1, 1975-1979. [CrossRef]

446. Kopetzki, D.; Antonietti, M. Hydrothermal formose reaction. New J. Chem. 2011, 35, 1787-1794. [CrossRef]

447. Lambert, J.B.; Gurusamy-Thangavelu, S.A.; Ma, K. The silicate-mediated formose reaction: Bottom-up synthesis of sugar silicates. Science 2010, 327, 984-986. [CrossRef]

448. Eschenmoser, A. On a hypothetical generational relationship between $\mathrm{HCN}$ and constituents of the reductive citric acid cycle. Chem. Biodivers. 2007, 4, 554-573. [CrossRef]

449. Stovbun, S.V.; Skoblin, A.A.; Zanin, A.M.; Tverdislov, V.A.; Taran, O.P.; Parmon, V.N. Formation of chiral structures in UV-initiated formose reaction. Phys. Chem. 2018, 479, 57-60. [CrossRef]

450. Breslow, R.; Cheng, Z.-L. L-amino acids catalyze the formation of an excess of D-glyceraldehyde, and thus of other D sugars, under credible prebiotic conditions. Proc. Natl. Acad. Sci. USA 2010, 107, 5723-5725. [CrossRef]

451. Burroughs, L.; Clarke, P.A.; Forintos, H.; Gilks, J.A.R.; Hayes, C.J.; Vale, M.E.; Wade, W.; Zbytniewski, M. Asymmetric organocatalytic formation of protected and unprotected tetroses under potentially prebiotic conditions. Org. Biomol. Chem. 2012, 10, 1565-1570. [CrossRef]

452. Bolm, C.; Mocci, R.; Schumacher, C.; Turberg, M.; Puccetti, F.; Hernández, J.G. Mechanochemical activation of iron cyano complexes: A prebiotic impact scenario for the synthesis of $\alpha$-amino acid derivatives. Angew. Chem. 2018, 130, 2447-2450. [CrossRef]

453. Eguaogie, O.; Vyle, J.S.; Conlon, P.F.; Gîlea, M.A.; Liang, Y. Mechanochemistry of nucleosides, nucleotides and related materials. Beilstein J. Org. Chem. 2018, 14, 955-970. [CrossRef] [PubMed]

454. Lamour, S.; Pallmann, S.; Haas, M.; Trapp, O. Prebiotic sugar formation under nonaqueous conditions and mechanochemical acceleration. Life 2019, 9, 52. [CrossRef] [PubMed]

455. Stolar, T.; Grubešić, S.; Cindro, N.; Meštrović, E.; Užarević, K.; Hernández, J.G. Mechanochemical prebiotic peptide bond formation. Angew. Chem. Int. Ed. 2021, 60, 12727-12731. [CrossRef]

456. Porcheddu, A.; Colacino, E.; De Luca, L.; Delogu, F. Metal-mediated and metal-catalyzed reactions under mechanochemical conditions. ACS Catal. 2020, 10, 8344-8394. [CrossRef] 
457. Goldanskii, V.I. Nontraditional pathways of extraterrestrial formation of prebiotic matter. J. Phys. Chem. A 1997, 101, 3424-3432. [CrossRef]

458. Rodríguez, B.; Bruckmann, A.; Bolm, C. A highly efficient asymmetric organocatalytic Aldol reaction in a ball mill. Chem. A Eur. J. 2007, 13, 4710-4722. [CrossRef]

459. Mateti, S.; Mathesh, M.; Liu, Z.; Tao, T.; Ramireddy, T.; Glushenkov, A.M.; Yang, W.; Chen, Y.I. Mechanochemistry: A force in disguise and conditional effects towards chemical reactions. Chem. Commun. 2021, 57, 1080-1092. [CrossRef]

460. Fiss, B.G.; Richard, A.J.; Friščić, T.; Moores, A. Mechanochemistry for sustainable and efficient dehydrogenation/hydrogenation. Can. J. Chem. 2020, 99, 93-112. [CrossRef]

461. Baig, R.B.N.; Varma, R.S. Alternative energy input: Mechanochemical, microwave and ultrasound-assisted organic synthesis. Chem. Soc. Rev. 2012, 41, 1559-1584. [CrossRef]

462. Jiménez-González, C.; Constable, D.J.C.; Ponder, C.S. Evaluating the "Greenness" of chemical processes and products in the pharmaceutical industry-a green metrics primer. Chem. Soc. Rev. 2012, 41, 1485-1498. [CrossRef]

463. Do, J.-L.; Friščić, T. Mechanochemistry: A force of synthesis. ACS Cent. Sci. 2017, 3, 13-19. [CrossRef] [PubMed]

464. Achar, T.K.; Bose, A.; Mal, P. Mechanochemical synthesis of small organic molecules. Beilstein J. Org. Chem. 2017, 13, 1907-1931. [CrossRef] [PubMed]

465. Baláž, P.; Baláž, M.; Achimovičová, M.; Bujňáková, Z.; Dutková, E. Chalcogenide mechanochemistry in materials science: Insight into synthesis and applications (a review). J. Mater. Sci. 2017, 52, 11851-11890. [CrossRef]

466. Chyba, C.F.; Thomas, P.J.; Brookshaw, L.; Sagan, C. Cometary delivery of organic molecules to the early Earth. Science 1990, 249, 366-373. [CrossRef]

467. Chyba, C.; Sagan, C. Endogenous production, exogenous delivery and impact-shock synthesis of organic molecules: An inventory for the origins of life. Nature 1992, 355, 125-132. [CrossRef]

468. Bernstein, M. Prebiotic materials from on and off the early Earth. Philos. Trans. R. Soc. Lond. B Biol. Sci. 2006, 361, 1689-1702. [CrossRef]

469. Pierazzo, E.; Chyba, C. Impact delivery of prebiotic organic matter to planetary surfaces. In Comets and the Origin and Evolution of Life. Advances in Astrobiology and Biogeophysics; Thomas, P.J., Hicks, R.D., Chyba, C.F., McKay, C.P., Eds.; Springer: Berlin/Heidelberg, Germany, 2006; pp. 137-168. [CrossRef]

470. Hörz, F.; Cintala, M.J. Impact experiments related to the evolution of planetary regoliths. Meteorit. Planet. Sci. 1997, 32, 179-209. [CrossRef]

471. Hörz, F.; Basilevsky, A.T.; Head, J.W.; Cintala, M.J. Erosion of lunar surface rocks by impact processes: A synthesis. Planet Space Sci. 2020, 194, 105105. [CrossRef]

472. Peterson, E.; Hörz, F.; Chang, S. Modification of amino acids at shock pressures of 3.5 to 32 GPa. Geochim. Cosmochim. Acta 1997, 61,3937-3950. [CrossRef]

473. Martins, Z.; Price, M.C.; Goldman, N.; Sephton, M.A.; Burchell, M.J. Shock synthesis of amino acids from impacting cometary and icy planet surface analogues. Nat. Geosci. 2013, 6, 1045-1049. [CrossRef]

474. McCaffrey, V.P.; Zellner, N.E.B.; Waun, C.; Bennett, E.R.; Karl, E.K. Reactivity and survivability of glycolaldehyde in simulated meteorite impact experiments. Orig. Life Evol. Biosph. 2014, 44, 29-42. [CrossRef] [PubMed]

475. Sugahara, H.; Mimura, K. Shock-induced pyrolysis of amino acids at ultra high pressures ranged from 3.2 to 35.3 GPa. J. Anal. Appl. Pyrolysis 2014, 108, 170-175. [CrossRef]

476. Sugahara, H.; Mimura, K. Glycine oligomerization up to triglycine by shock experiments simulating comet impacts. Geochem. J. 2014, 48, 51-62. [CrossRef]

477. Sugahara, H.; Mimura, K. Peptide synthesis triggered by comet impacts: A possible method for peptide delivery to the early Earth and icy satellites. Icarus 2015, 257, 103-112. [CrossRef]

478. Frantseva, K.; Mueller, M.; ten Kate, I.L.; van der Tak, F.F.S.; Greenstreet, S. Delivery of organics to Mars through asteroid and comet impacts. Icarus 2018, 309, 125-133. [CrossRef]

479. Jaramillo-Botero, A.; Cable, M.L.; Hofmann, A.E.; Malaska, M.; Hodyss, R.; Lunine, J. Understanding hypervelocity sampling of biosignatures in space missions. Astrobiology 2020, 21, 421-442. [CrossRef]

480. Klenner, F.; Postberg, F.; Hillier, J.; Khawaja, N.; Cable, M.L.; Abel, B.; Kempf, S.; Glein, C.R.; Lunine, J.I.; Hodyss, R.; et al. Discriminating abiotic and biotic fingerprints of amino acids and fatty acids in ice grains relevant to ocean worlds. Astrobiology 2020, 20, 1168-1184. [CrossRef]

481. Des Marais, D.J.; Nuth, J.A., III; Allamandola, L.J.; Boss, A.P.; Farmer, J.D.; Hoehler, T.M.; Jakosky, B.M.; Meadows, V.S.; Pohorille, A.; Runnegar, B.; et al. The NASA Astrobiology Roadmap. Astrobiology 2008, 8, 715-730. [CrossRef]

482. Beegle, L.W.; Bhartia, R.; White, M.; DeFlores, L.; Abbey, W.; Wu, Y.-H.; Cameron, B.; Moore, J.; Fries, M.; Burton, A.; et al. SHERLOC: Scanning Habitable Environments with Raman \& Luminescence for Organics \& Chemicals. In Proceedings of the IEEE Aerospace Conference, Big Sky, MT, USA, 7-14 March 2015. [CrossRef]

483. Bhartia, R.; Beegle, L.W.; DeFlores, L.; Abbey, W.; Razzell Hollis, J.; Uckert, K.; Monacelli, B.; Edgett, K.S.; Kennedy, M.R.; Sylvia, M.; et al. Perseverance's Scanning Habitable Environments with Raman and Luminescence for Organics and Chemicals (SHERLOC) Investigation. Space Sci. Rev. 2021, 217, 58. [CrossRef]

484. Meierhenrich, U.J.; Thiemann, W.H.; Goesmann, F.; Roll, R.; Rosenbauer, H. Enantiomer separation of hydrocarbons in preparation for ROSETTA's “chirality-experiment". Chirality 2001, 13, 454-457. [CrossRef] 
485. Szopa, C.; Sternberg, R.; Coscia, D.; Raulin, F.; Vidal-Madjar, C.; Rosenbauer, H. Gas chromatography for in situ analysis of a cometary nucleus III. Multi-capillary column system for the cometary sampling and composition experiment of the Rosetta lander probe. J. Chromatogr. A 2002, 953, 165-173. [CrossRef]

486. Bibring, J.-P.; Rosenbauer, H.; Boehnhardt, H.; Ulamec, S.; Biele, H.; Espinasees, S.; Feuerbacher, B.; Gaudon, P.; Hemmerich, P.; Kletzkine, P.; et al. The Rosetta lander ("Philae") investigations. Space Sci. Rev. 2007, 128, 205-220. [CrossRef]

487. Goesmann, F.; Rosenbauer, H.; Bredehöft, J.H.; Cabane, M.; Ehrenfreund, P.; Gautier, T.; Giri, C.; Krüger, H.; Le Roy, L.; MacDermott, A.J.; et al. Organic compounds on comet 67P/Churyumov-Gerasimenko revealed by COSAC mass spectrometry. Science 2015, 349, aab0689. [CrossRef]

488. Sephton, M.A.; Carter, J.N. The chances of detecting life on Mars. Planet. Space Sci. 2015, 112, 15-22. [CrossRef]

489. Fairén, A.G.; Parro, V.; Schulze-Makuch, D.; Whyte, L. Is searching for Martian life a priority for the Mars community? Astrobiology 2018, 18, 101-107. [CrossRef]

490. Carrier, B.L.; Beaty, D.W.; Meyer, M.A.; Blank, J.G.; Chou, L.; DasSharma, S.; Des Marais, D.J.; Eigenbrode, J.L.; Grefenstette, N.; Lanza, N.L.; et al. Mars extant life: What's next? Conference Report. Astrobiology 2020, 20, 785-814. [CrossRef]

491. Steele, A.; McCubbin, F.M.; Fries, M.; Kater, L.; Boctor, Z.; Fogel, M.L.; Conrad, P.G.; Glamocija, M.; Spencer, M.; Morrow, A.L.; et al. A reduced organic carbon component in Martian basalts. Science 2012, 337, 212-215. [CrossRef]

492. Steele, A.; McCubbin, F.M.; Fries, M.D. The provenance, formation, and implications of reduced carbon phases in Martian meteorites. Meteorit. Planet. Sci. 2016, 51, 2203-2225. [CrossRef]

493. Steele, A.; Benning, L.G.; Wirth, R.; Schreiber, A.; Araki, T.; McCubbin, F.M.; Fries, M.D.; Nittler, L.R.; Wang, J.; Hallis, L.J.; et al. Organic synthesis associated with serpentinization and carbonation on early Mars. Science 2022, 375, 172-177. [CrossRef]

494. Grotzinger, J.P.; Crisp, J.; Vasavada, A.R.; Anderson, R.C.; Baker, C.J.; Barry, R.; Blake, D.F.; Conrad, P.; Edgett, K.S.; Ferdowski, B.; et al. Mars Science Laboratory mission and science investigation. Space Sci. Rev. 2012, 170, 5-56. [CrossRef]

495. Farley, K.A.; Williford, K.H.; Stack, K.M.; Bhartia, R.; Chen, A.; de la Torre, M.; Hand, K.; Goreva, Y.; Herd, C.D.K.; Hueso, R.; et al. Mars 2020 mission overview. Space Sci. Rev. 2020, 216, 142. [CrossRef]

496. Millan, M.; Szopa, C.; Buch, A.; Cabane, M.; Teinturier, S.; Mahaffy, P.; Johnson, S.S. Performance of the SAM gas chromatographic columns under simulated flight operating conditions for the analysis of chlorohydrocarbons on Mars. J. Chromatogr. A 2019, 1598, 183-195. [CrossRef] [PubMed]

497. Quantin-Nataf, C.; Carter, J.; Mandon, L.; Thollot, P.; Balme, M.; Volat, M.; Pan, L.; Loizeau, D.; Millot, C.; Breton, S.; et al. Oxia Planum: The landing site for the ExoMars "Rosalind Franklin" rover mission: Geological context and prelanding interpretation. Astrobiology 2021, 21, 345-366. [CrossRef] [PubMed]

498. Vago, J.L.; Westall, F.; Pasteur Instrument Teams; Landing Site Selection Working Group and Other Contributors; Coates, A.J.; Jaumann, R.; Korablev, O.; Ciarletti, V.; Mitrofanov, I.; Josset, J.-L.; et al. Habitability on early Mars and the search for biosignatures with the ExoMars rover. Astrobiology 2017, 17, 471-510. [CrossRef]

499. Razzell Hollis, J.; Ireland, S.; Abbey, W.; Bhartia, R.; Beegle, L.W. Deep-ultraviolet Raman spectra of Mars-relevant evaporite minerals under $248.6 \mathrm{~nm}$ excitation. Icarus 2021, 357, 114067. [CrossRef]

500. Abrahamsson, V.; Henderson, B.L.; Herman, J.; Zhong, F.; Lin, Y.; Kanik, I.; Nixon, C.A. Extraction and separation of chiral amino acids for life detection on ocean worlds without using organic solvents or derivatization. Astrobiology 2021, 21, 575-586. [CrossRef]

501. Foroughbakhshfasaei, M.; Dobó, M.; Boda, F.; Szabó, Z.; Tóth, G. Comparative chiral separation of thalidomide class of drugs using polysaccharide-type stationary phases with emphasis on elution order and hysteresis in polar organic mode. Molecules 2022, 27, 111. [CrossRef]

502. Gao, L.; Zhao, X.; Qin, S.; Dong, Q.; Hu, X.; Chu, H. A covalent organic framework for chiral capillary electrochromatography using a cyclodextrin mobile phase additive. Chirality 2022, 24, 537-549. [CrossRef]

503. Li, X.-L.; Han, Y.; Huang, Y.; Sun, X.; Xiao, S.; Min, J.Z. Highly sensitive novel fluorescent chiral probe possessing (S)-2methylproline structures for the determination of chiral amino compounds by ultra-performance liquid chromatography with fluorescence: An application in the saliva of healthy volunteer. J. Chromatogr. A 2022, 1661, 462672. [CrossRef]

504. Niu, X.; Yan, S.; Chen, J.; Li, H.; Wang, K. Enantioselective recognition of L/D-amino acids in the chiral nanochannels of a metal-organic framework. Electrochim. Acta 2022, 405, 139809. [CrossRef]

505. Arevalo, R., Jr.; Ni, Z.; Danell, R.M. Mass spectrometry and planetary exploration: A brief review and future projection. J. Mass Spectrom. 2020, 55, e4454. [CrossRef]

506. Chou, L.; Mahaffy, P.; Trainer, M.; Eigenbrode, J.; Arevalo, R.; Brinckerhoff, W.; Getty, S.; Grefenstette, N.; Da Poian, V.; Fricke, G.M.; et al. Planetary mass spectrometry for agnostic life detection in the Solar System. Front. Astron. Space Sci. 2021, 8, 755100. [CrossRef]

507. Willis, P.A.; Creamer, J.S.; Mora, M.F. Implementation of microchip electrophoresis instrumentation for future spaceflight missions. Anal. Bioanal. Chem. 2015, 407, 6939-6963. [CrossRef]

508. Creamer, J.S.; Mora, M.F.; Willis, P.A. Enhanced resolution of chiral amino acids with capillary electrophoresis for biosignature detection in extraterrestrial samples. Anal. Chem. 2017, 89, 1329-1337. [CrossRef]

509. Creamer, J.S.; Mora, M.F.; Willis, P.A. Stability of reagents used for chiral amino acid analysis during spaceflight missions in high-radiation environments. Electrophoresis 2018, 39, 2864-2871. [CrossRef] 
510. Dong, Z.; Ma, Y. Atomic-level handedness determination of chiral crystals using aberration-corrected scanning transmission electron microscopy. Nat. Commun. 2020, 11, 1588. [CrossRef]

511. Eigenbrode, J.L.; Gold, R.; Canham, J.S.; Schulze, E.; Davila, A.F.; Seas, A.; Errigo, T.; Kujawa, F.; Kusnierkiewicz, D.; Lorentson, C.; et al. Contamination control for ultra-sensitive life-detection missions. Front. Space Technol. 2021, 2, 734423. [CrossRef]

512. Spiers, E.M.; Weber, J.M.; Venigalla, C.; Annex, A.M.; Chen, C.P.; Lee, C.; Gray, P.C.; McIntyre, K.J.; Berdis, J.R.; Carberry Mogan, S.R.; et al. Tiger: Concept study for a New Frontiers Enceladus habitability mission. Planet. Sci. J. 2021, 2, 195. [CrossRef]

513. Hendrickson, R.; Urbaniak, C.; Minich, J.J.; Aronson, H.S.; Martino, C.; Stepanauskas, R.; Knight, R.; Venkateswaran, K. Clean room microbiome complexity impacts planetary protection bioburden. Microbiome 2021, 9, 238. [CrossRef]

514. Glavin, D.P.; Dworkin, J.P.; Lupisella, M.; Kminek, G.; Rummel, J.D. Biological contamination studies of lunar landing sites: Implications for future planetary protection and life detection on the Moon and Mars. Int. J. Astrobiol. 2005, 3, 265-271. [CrossRef]

515. Glavin, D.P.; Freissinet, C.; Miller, K.E.; Eigenbrode, J.L.; Brunner, A.E.; Buch, A.; Sutter, B.; Archer, P.D.; Atreya, S.K.; Brinckerhoff, W.B.; et al. Evidence for perchlorates and the origin of chlorinated hydrocarbons detected by SAM at the Rocknest aeolian deposit in Gale Crater. JGR Planets 2013, 118, 1955-1973. [CrossRef]

516. Miller, K.E.; Kotrc, B.; Summons, R.E.; Belmahdi, I.; Buch, A.; Eigenbrode, J.L.; Freissinet, C.; Glavin, D.P.; Szopa, C. Evaluation of the Tenax trap in the Sample Analysis at Mars instrument suite on the Curiosity rover as a potential hydrocarbon source for chlorinated organics detected in Gale Crater. JGR Planets 2015, 120, 1446-1459. [CrossRef]

517. Craven, E.; Winters, M.; Smith, A.L.; Lalime, E.; Mancinelli, R.; Shirey, B.; Schubert, W.; Schuerger, A.; Burgin, M.; Seto, E.P.; et al. Biological safety in the context of backward planetary protection and Mars Sample Return: Conclusions from the Sterilization Working Group. Int. J. Astrobiol. 2021, 20, 1-28. [CrossRef]

518. Longo, A.; Damer, B. Factoring origin of life hypotheses into the search for life in the Solar System and beyond. Life 2020, 10, 52. [CrossRef] 